$$
\text { Universidade de São Paulo }
$$

Faculdade de Filosofia, Ciências e Letras de Ribeirão Preto

Programa de Pós-Graduação em Psicologia

Departamento de Psicologia

\title{
A Humanização na Disciplina de Odontopediatria a Partir das Vivências dos Estudantes na Clínica-escola.
}

\author{
Luiza Loredanna Moraes Stedile
}

Dissertação apresentada à Faculdade de Filosofia Ciências e Letras de Ribeirão Preto da Universidade de São Paulo, como parte das exigências para obtenção do Título de Mestre em Ciências.

Área de Concentração: Psicologia em Saúde e Desenvolvimento.

Apoio: Capes

\section{Ribeirão Preto}



Universidade de São Paulo

Faculdade de Filosofia, Ciências e Letras de Ribeirão Preto

Programa de Pós-Graduação em Psicologia

Departamento de Psicologia

\section{A Humanização na Disciplina de Odontopediatria a Partir das Vivências dos Estudantes na Clínica-escola \\ Versão Corrigida}

\section{Luiza Loredanna Moraes Stedile}

Orientadora: Professora Doutora Cármen Lúcia Cardoso

Dissertação apresentada à Faculdade de Filosofia Ciências e Letras de Ribeirão Preto da Universidade de São Paulo, como parte das exigências para obtenção do Título de Mestre em Ciências.

Área de Concentração: Psicologia em Saúde e Desenvolvimento.

Apoio: Capes

Ribeirão Preto 
Autorizo a reprodução e divulgação total ou parcial deste trabalho, por qualquer meio convencional ou eletrônico, para fins de estudo e pesquisa, desde que citada a fonte.

FICHA CATALOGRÁFICA

Stedile, Luiza Loredanna Moraes

A humanização na Disciplina de Odontopediatria a Partir das Vivências dos Estudantes na Clínica-escola. Ribeirão Preto, 2019.

125 p. : il. ; $30 \mathrm{~cm}$

Dissertação de Mestrado, apresentada à Faculdade de Filosofia, Ciências e Letras de Ribeirão Preto/USP. Área de concentração: Psicologia da Saúde e Desenvolvimento.

Orientadora: Cardoso, Cármen Lúcia.

1. Odontopediatria. 2. Psicologia. 3. Humanização da Assistência.

4. Estudantes de Odontologia 5. Odontologia em Saúde Pública 
Stedile, Luiza Loredanna Moraes

A Humanização na Disciplina de Odontopediatria a Partir das Vivências dos Estudantes na Clínica-escola

Dissertação apresentada à Faculdade de Filosofia, Ciências e Letras de Ribeirão Preto da Universidade de São Paulo, como parte das exigências para a obtenção do título de Mestre em Ciências.

Área de concentração: Psicologia em Saúde e Desenvolvimento.

Aprovado em:

Banca Examinadora

Prof. Dr.

Instituicao:

Julgamento:

Assinatura:

Prof. Dr.

Instituicao:

Julgamento:

Assinatura:

Prof. Dr.

Instituicao:

Julgamento:

Assinatura: 



\section{AGRADECIMENTOS}

Aos participantes desse estudo que interromperam suas atividades para dedicar um tempo a compartilhar comigo suas experiências. Meu muito obrigada à solicitude com que cada um respondeu ao meu contato.

À minha Orientadora, Carmen, que me possibilitou tanto aprendizado e amadurecimento durante esse percurso. Muito obrigada pela acolhida, pela oportunidade e por acreditar em mim. Por me proporcionar tanto! Com você aprendi que com dedicação, compromisso e amor pelo que se faz nossos sonhos não têm limites. Entre vivências acadêmicas e afeto, sua presença é luz na minha vida.

À Lícia, Psicóloga da USP, companheira de Laboratório e agora minha querida amiga do coração. Obrigada pelo tempo despendido em contribuir com parte desse trabalho e, principalmente, pela amizade que trouxe sol aos dias nublados. Foram tantos sorrisos compartilhados que agora entendo a leveza que é te ter por perto.

À Ana Alayde, minha orientadora de iniciação científica, estágio e TCC, que me iniciou em muitos caminhos tão importantes. Seu amor (não posso usar aquela nossa palavra aqui, tá?) pela psicologia, pesquisa e docência me mostrou que a cooperação faz com que todos cresçam juntos e é a melhor forma de aprendizado. Muito obrigada por tudo o que compartilhamos, por todas as experiências lindas que me proporcionou e por ter me dado espaço para crescer e chegar até aqui. Estendo esse agradecimento aos queridos amigos que fiz no NPVPS, levo cada um de vocês sempre em meu coração.

Aos meus pais, Nilo e Luiza por todo o amparo afetivo que desde sempre me foi dado. Por serem colo, abrigo, amparo e só amor. Por todo o esforço para dar a mim e meus irmãos uma educação de qualidade que nos permitisse chegar onde quiséssemos. Por acreditarem em mim muito mais que eu mesma. Sem vocês eu não 
teria chegado tão longe e com vocês não há limites para meus sonhos. Vocês são os melhores e a nossa família é o bem mais preciso que há, o melhor lugar para se estar.

Aos meus irmãos, Diego e Rannier, pela amizade e companheirismo. Por toda a proteção de uma vida. Por me ensinarem que quando se tem irmãos, não importa o quão longe eles estejam, você nunca estará só. Carrego vocês sempre no meu coração. Vocês são combustível para os dias de saudade, são os melhores amigos que eu poderia ter na vida. Obrigada pelo suporte, por vezes até financeiro, para que eu chegasse até aqui. Sem vocês faltaria uma importante parte de mim. Estendo esse agradecimento à Aretusa, que não é irmã de sangue, mas é de alma e coração. Muito obrigada por tanto, por sempre estar disponível, por todos os sorrisos e lágrimas compartilhadas, pelo suporte - em todos os sentidos - que sempre me deu para que eu chegasse até aqui. O "upgrade" de te ter como irmã foi uma das melhores coisas que me aconteceu. Aos seus filhos, Gabriel e Giulia, agradeço por encherem meus dias de alegria e por me apresentarem à forma mais pura de amor.

À Suelane Maria (in memorian) por ter aberto sua casa para mim durante minha graduação em João Pessoa. Por ter me dado uma família linda de presente e ter me feito sentir tão igualmente amada quanto suas filhas. Seu amparo foi fundamental. Meu muito obrigada também às suas filhas, Érika e Jéssica por tanta coisa compartilhada e por terem me feito sentir tão parte dessa família e ao seu então esposo Salvador, pela forma atenciosa e respeitosa com que sempre me tratou. Essa família para sempre também será minha.

Aos meus Tios Ribaiza e Geraldo, que no inicio da minha graduação gentilmente me acolheram em sua casa, me fazendo parte de sua família. $O$ suporte de vocês foi fundamental naquele momento onde, em meio tantas dificuldades que eu tinha para estar longe de casa, vocês não mediram esforços para que nada me faltasse. Agradeço pelos sorrisos compartilhados, sou muito feliz por tê-los fazendo parte dessa história. 
Às minhas colegas de Laboratório Lícia, Nathália, Mara, Bruna, Ana Paula, Marília, Ana Flávia e Lydiane, pelas muitas contribuições dadas na construção desse trabalho.

Às minhas amigas de infância e da época de escola que estão sempre ao meu lado, compartilhando sorrisos e tornando minha vida mais leve e cheia de amor. Dayane, Mayara, Natália e Socorrinha, obrigada por tantas memórias felizes e por todos os encontros que faço comigo mesma quando estamos juntas.

Às minhas amadas amigas da graduação Astrid, Carla e Thaynara com quem vivi tantos momentos indescritíveis de amizade sincera, apoio, sorrisos, choros. Vocês por muitas vezes foram meu lar fora de casa. Obrigada por terem feito meus dias em João Pessoa muito mais felizes e cheios de amor.

Aos queridos amigos Flávia, Bruno, Letícia, Júlia e Mariana, conquistados em Ribeirão Preto, pela acolhida, pelos momentos tão nossos vivenciados durante esse tempo. Obrigada por me fazerem facilmente sentir em casa na presença de cada de vocês.

Às Professoras Marina Simões Flório Ferreira Bertagnoli e Karin Cassarini pelas contribuições durante o exame de qualificação.

À Faculdade de Filosofia, Ciências e Letras de Ribeirão Preto (FFCLRP - USP) e seus funcionários e professores por oferecerem o apoio e a estrutura necessária para a realização desse estudo.

À Capes pelo apoio financeiro imprescindível para o desenvolvimento desse estudo. 



\section{RESUMO}

Stedile, L.L.M. (2019). A Humanização na Disciplina de Odontopediatria a partir das Vivências dos Estudantes na Clínica-escola. Dissertação de Mestrado, Departamento de Psicologia, Faculdade de Filosofia, Ciências e Letras de Ribeirão Preto, Universidade de São Paulo.

O exercício da Odontologia, apesar de ser uma atividade antiga, tem ganhado uma maior visibilidade na literatura científica contemporânea sob a ótica da humanização em saúde, que se refere tanto à sua prática profissional quanto ao processo de ensinoaprendizagem. Objetivou-se compreender as vivências de graduandos de Odontologia frente à formação para o atendimento odontopediátrico, bem como a humanização dos serviços prestados e das relações estabelecidas nesse contexto. Para tanto, foi realizado um estudo descritivo de abordagem qualitativa, tendo como instrumento uma entrevista semiestruturada, composta de quatro questões norteadoras. Os dados obtidos foram analisados seguindo os princípios da Análise de Conteúdo Temática e discutidos a partir de autores da saúde coletiva. Os resultados foram organizados em dois eixos de análise, a saber: Eixo I: Dificuldades na Clínica-escola: do saber técnico às vivências na clínica, que foi desdobrado em três subeixos: Especificidades do atendimento à criança na Clínica-escola; A complexidade nas relações com os acompanhantes; Desafios na articulação entre formação teórica e a prática do atendimento à criança; e Eixo II: Humanização nas práticas da Clínica-escola: percepções, vivências e desafios, com os subeixos "A humanização na prática odontopediátrica e Dificuldades e desafios para a humanização dos atendimentos na Clínica-escola". O primeiro Eixo de análise abordou as dificuldades vivenciadas pelos estudantes na Clínica-escola de Odontopediatria. Os alunos relataram suas experiências e sentimentos em relação a diversos aspectos presentes na dinâmica da Clínica, no que se refere às relações interpessoais e aos atendimentos realizados. $O$ segundo Eixo apresentou a apropriação que os alunos fazem sobre o processo de humanização nas vivências e no cuidado em saúde na Clínica Odontopediátrica. Os relatos versaram sobre como os estudantes significam a humanização, como percebem sua prática no contexto estudado e os desafios para sua efetivação. A análise do corpus apontou que o processo de ensino-aprendizagem, no contexto estudado, enfatiza os procedimentos técnicos imersos nas contradições suscitadas nas tentativas de aplicação de práticas humanizadas. Ressalta-se que as práticas ocorrem em um ambiente por vezes ansiogênico, competitivo e pautado em posturas assimétricas e relações interpessoais marcadas pelo distanciamento. Em síntese, o estudo aponta para a necessidade de que a questão da humanização saia do discurso e se atualize no "fazer" em saúde, sendo que um projeto integrado de ensinoaprendizagem entre as disciplinas de Psicologia e de Odontopediatria pode favorecer o desenvolvimento de práticas mais alinhadas ao cuidado integral e humanizado.

Palavras-chave: Odontopediatria. Psicologia. Humanização da Assistência. Estudantes de Odontologia. Odontologia em Saúde Pública. 



\begin{abstract}
Stedile, L.L.M. (2019). Humanization in the Discipline of Pediatric Dentistry from the Experiences of Students in the Clinic. Master's Dissertation, Department of Psychology, Faculty of Philosophy, Sciences and Letters of Ribeirão Preto, University of São Paulo.
\end{abstract}

The practice of Dentistry, despite being an old activity, has been widely disseminated in the literature from the point of view of humanization in health, which refers to both the practice and the teaching-learning process. The goal of this research was to understand the experiences of undergraduates of Dentistry in the training for pediatric dentistry care, as well as the humanization of the services provided and the relations established in this context. A descriptive study of a qualitative approach was carried out, using as a instrument a semi-structured interview, composed of four guiding questions. The data obtained were analyzed according to the principles of the Thematic Content Analysis and discussed from authors of collective health. The results were organized in two Axes of Analysis, namely: Axis I: Difficulties in the School Clinic: from the technical knowledge to the experiences in the clinic, which was devided in three sub-axes: Child care specificities in the School Clinic; The complexity in the relations with the companions; Challenges in the articulation between theoretical formation and the practice of the child care; and Axis II: Humanization in School Clinic practices: perceptions, experiences and challenges, with the sub-axes "Humanization in pediatric dentistry practice and Difficulties and challenges for the humanization of Clinic-School care". The first Axis of analysis discussed the difficulties experienced by the students in the pediatric dentistry school clinic. The students reported their experiences and feelings in relation to several aspects present in the dynamics of the Clinic, regarding the interpersonal relationships and the care given. The second Axis presented the appropriation that the students make about the process of humanization in the experiences and health care in the Pediatric Clinic. The reports dealt with how students mean humanization, how they perceive their practice in the context studied, and the challenges to their realization. The analysis of the corpus pointed out that the teaching-learning process, in the context studied, emphasizes the technical procedures immersed in the contradictions raised in the attempts to apply humanized practices. It is emphasized that the practices occur in an environment sometimes anxiogenic, competitive and based on asymmetric positions and interpersonal relations marked by distance. In summary, the study points to the need for the issue of humanization to leave the discourse and be updated in the "doing" in health, and an integrated teachinglearning project between the disciplines of Psychology and Pediatric Dentistry can favor the development of practices that are more in line with integral and humanized care.

Keywords: Pediatric Dentistry. Psychology. Humanization of Assistance. Students of Dentistry. Dentistry in Public Health. 



\section{LISTA DE QUADROS}

Quadro 1 - Apresentação dos Eixos de Análise do Corpus 58 



\section{LISTA DE SIGLAS}

$\begin{array}{ll}\text { AAPD } & \text { American Academy of Pediatric Dentistry } \\ \text { DCN } & \text { Diretrizes Curriculares Nacionais } \\ \text { FFCLRP } & \begin{array}{l}\text { Faculdade de Filosofia, Ciências e Letras de Ribeirão } \\ \text { LDB }\end{array} \\ \text { PNH } & \text { Lei de Diretrizes e Bases } \\ \text { SUS } & \text { Sistema Único de Saúde } \\ \text { USP } & \text { Universidade de São Paulo }\end{array}$





\section{SUMÁRIO}

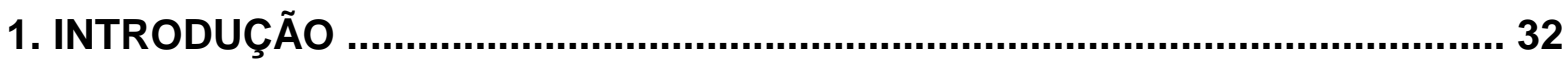

1.1. História da Odontologia e o Modelo Biomédico ............................................. 32

1.2. Humanização em Saúde Pública e Política Nacional de

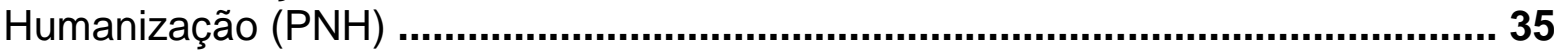

1.3. Humanização em Odontopediatria e o Atendimento no Contexto da Clínica-escola .................................................................................. 38

1.4. Processo Ensino-Aprendizagem em Odontologia .......................................... 40

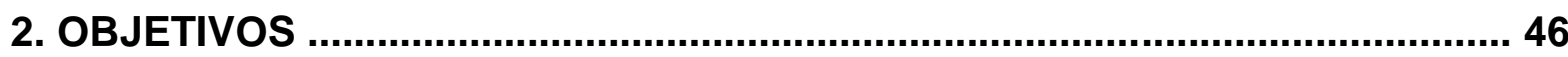

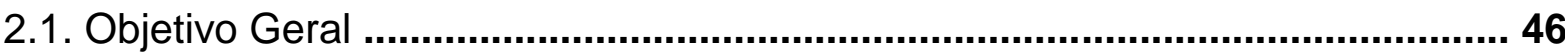

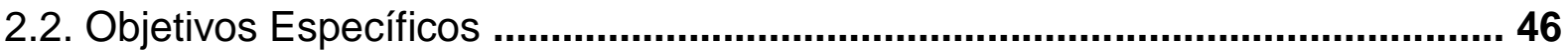

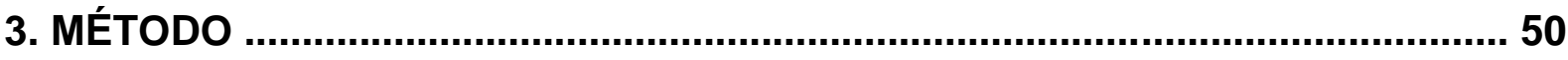

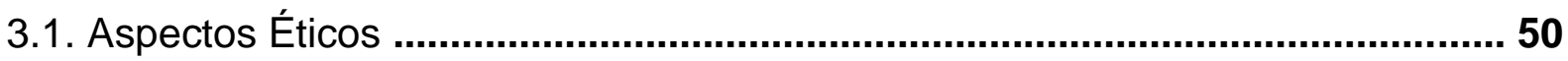

3.2. Constituição do Corpus ............................................................................... 51

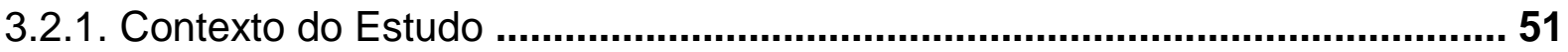

3.2.2. Caracterização dos Participantes ............................................................... 52

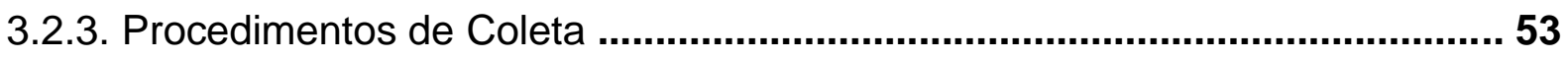

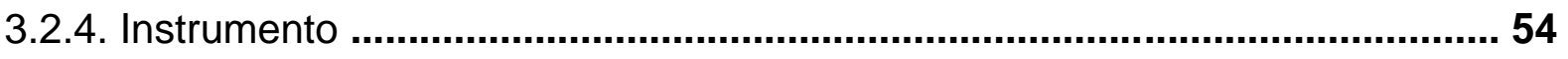

3.2.5. Percurso de Análise do Corpus ................................................................ 55

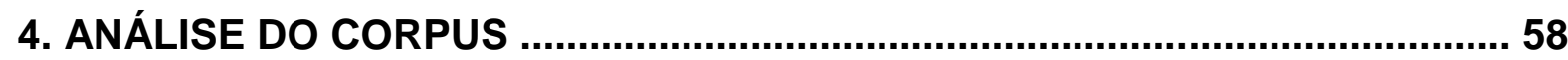

4.1. Eixo I: Dificuldades na Clínica-escola: do saber técnico às vivências

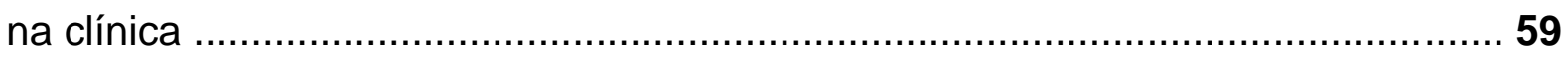

4.1.1. Especificidades do atendimento à criança na Clínica-escola ....................... 59

4.1.2. A Complexidade nas relações com os acompanhantes ............................. 71 
4.1.3. Desafios na articulação entre formação teórica e a prática do atendimento à criança ......

4.2. Eixo II: Humanização nas Práticas da Clínica-escola: concepções, vivências e desafios 87

4.2.1. A Humanização da Prática Odontopediátrica 88

4.2.2. Dificuldades e desafios para a humanização dos atendimentos na

Clínica-escola

5. CONSIDERAÇÕES FINAIS 105

6. REFERÊNCIAS

7. APÊNDICE A: TERMO DE CONSENTIMENTO LIVRE E ESCLARECIDO...... 121

8. ANEXO A: Parecer Consubstanciado do Comitê de Ética em Pesquisa da FFCLRP-USP 125 



\section{APRESENTAÇÃO}

Meu percurso até chegar à Faculdade de Filosofia, Ciências e Letras de Ribeirão Preto da Universidade de São Paulo teve início ainda em Fortaleza-CE, quando aos dezoito anos de idade decidi que a Psicologia seria minha profissão de escolha para encarar o vestibular. No ano de 2009, aos dezenove anos, fui aprovada na Universidade Federal da Paraíba (UFPB) e mudei para a cidade de João Pessoa para dar início a essa caminhada que, por sorte ou destino, foi onde me encontrei.

Desde o início, procurei me envolver nas mais diferentes atividades dentro do curso para tentar descobrir minha área de interesse na Psicologia, afinal já entramos na faculdade com aquela pressão de que não há tempo a perder. E assim fiz. Ainda no primeiro ano, ingressei na "Actuar" Empresa Júnior de Psicologia e juntamente com os colegas veteranos organizamos o I Encontro Paraibano de Psicologia Organizacional e do Trabalho. Foi um evento inteiramente organizado por nós, então estudantes, com o apoio financeiro de alguns setores da UFPB, que contou com grandes nomes da área. Professores que gentilmente abraçaram nossa ideia e entusiasmo.

Depois disso, no segundo ano ingressei no Núcleo de Pesquisas em Desenvolvimento Sócio-Moral, sob a orientação do Professor Doutor Júlio Rique Neto. Lá pude dar os primeiros passos tímidos em busca de conhecer o que seria a pesquisa em Psicologia. Nesse momento ainda não participei diretamente de projeto de iniciação científica, mas contribui na coleta de dados de um estudo amplo de validação de escalas, do qual apresentei um recorte através de uma comunicação oral no Congresso Norte-Nordeste de Psicologia (Conpsi). Penso que nesse momento, com tantas coisas para viver dentro da academia, a pesquisa ainda não era a área que mais me interessava, então guardei esse interesse para mais tarde e decidi viver outras coisas.

Após decidir buscar novas experiências, ingressei como colaboradora no Centro Acadêmico de Psicologia. Não fazia parte da gestão oficial, mas estava engajada nas diversas atividades desempenhadas pelo grupo. No ano seguinte, agora como membro oficial da Gestão, pude juntamente com colegas de diferentes turmas 
desenvolver um trabalho bastante positivo dentro do curso. Nesse período de gestão, organizamos diversos eventos que objetivaram oferecer aos estudantes a possibilidade de conhecer as diversas áreas e abordagens dentro da Psicologia, espaços importantes de discussão e trocas. Dentre muitos eventos, realizamos 0 Encontro de Terapias, onde convidamos profissionais das diferentes abordagens terapêuticas a falar de suas experiências, organizamos palestras, minicursos e demos uma cara nova à Semana de Psicologia, que era um evento tradicional do Centro Acadêmico.

Durante esse percurso, pude amadurecer muitas habilidades e assumir pela primeira vez na academia uma postura profissional. Nesse momento, me vi perdendo a timidez para resolver assuntos burocráticos com pessoas de cargos importantes dentro da administração do Campus, para falar em público, fazer contato com profissionais importantes e compor comissões de recepção e acolhida. Foi uma experiência de muito crescimento.

Contemporaneamente a esses acontecimentos comecei a cursar a disciplina Psicologia da Saúde, ministrada pela Professora Mestra Laura Kumamoto. Esse foi meu primeiro contato com a Psicologia da Saúde e logo me identifiquei tão profundamente que iniciei por conta própria leituras de materiais da área. A Professora tinha um projeto de extensão universitária lindíssimo, chamado "Projeto de Apoio à Criança Hospitalizada: uma proposta de intervenção lúdica". Esse projeto atuava na pediatria do Hospital Universitário Lauro Wanderley e atendia as crianças internadas no setor de pediatria que, durante algum tempo, não contava com profissional fixo da psicologia. Tinha como objetivo a promoção de um ambiente facilitador à qualidade de vida das crianças hospitalizadas e de seus acompanhantes.

Conversei com a Professora Laura que, com toda sua doçura, me permitiu ingressar voluntariamente no projeto fora do período de seleção. Logo comecei a participar das reuniões de supervisão e me preparar teoricamente para iniciar os atendimentos na pediatria, bem como no bloco cirúrgico do hospital, onde era realizada preparação psicológica das crianças e seus acompanhantes para o momento da cirurgia. Pouco tempo após iniciar minha participação prática, houve o período de seleção interna no projeto para definir quem ficaria com a bolsa concedida 
pela universidade. Nesse momento, fui aprovada em primeiro lugar na e passei da condição de aluna voluntária para bolsista do projeto.

Passados dois anos atuando nesse contexto, senti que estava preparada para conhecer mais da pesquisa em psicologia, afinal agora eu já havia encontrado minha área de interesse e só precisava buscar um professor que acolhesse minha vontade de aprender. Nesse momento, a Professora Doutora Ana Alayde Saldanha abriu seleção para o Núcleo de Pesquisas em Vulnerabilidades e Promoção da Saúde NPVPS e ali vi minha chance de, agora mais madura e convicta do que buscava, iniciar esse novo caminho. Fui aprovada na seleção e posso dizer que as experiências vividas nesse momento foram de grande crescimento profissional e pessoal. A Professora Ana e os colegas do núcleo com toda a paciência e dedicação muito me ajudaram a trilhar passos importantes que me deram a base para chegar nesse momento da minha trajetória. No NPVPS desenvolvi dois estudos de iniciação científica, tendo publicado juntamente com colegas um artigo científico de recorte da segunda pesquisa.

Os dados obtidos para esse artigo publicado fazem parte de um projeto muito maior, que traçou um panorama representativo acerca das práticas e do acesso de saúde dos moradores das cidades rurais do estado da Paraíba. Viajamos por diversas cidades rurais paraibanas, fazendo entrevistas em sítios, fazendas, nas calçadas dos centros das cidades, praças. Ter contato com tantas histórias de vida numa realidade socioeconômica muitas vezes tão sofrida me fez enxergar claramente o papel social da psicologia nos diferentes contextos que ela ocupa. Fui profundamente transformada por essa vivência e carrego com muito carinho cada história vivida nas tantas viagens feitas e entrevistas realizadas sob o sol do sertão.

Ainda sob a supervisão da Professora Ana, realizei meu estágio de conclusão de curso também na pediatria do Hospital Universitário da UFPB e desenvolvi minha monografia. Após minha formatura contribui em alguns trabalhos realizados e comecei a perceber em mim a vontade de continuar essa trajetória acadêmica. Entendendo a importância de se deixar atravessar pelos diferentes tipos de pensamento e contextos, decidi que optaria por tentar uma vaga de mestrado numa faculdade diferente de onde me graduei. Após algumas pesquisas decidi que o Programa de Pós Graduação em 
Psicologia da FFCLRP-USP seria um ótimo lugar para continuar me capacitando profissionalmente.

Nessa pesquisa encontrei algumas publicações da Professora Doutora Carmen Lúcia Cardoso, minha orientadora, e iniciamos juntas um caminho de construção da nossa relação profissional e, hoje, de amizade e apoio. Conversamos à distância durante algum tempo, por telefone, para avaliarmos as diversas questões implicadas nessa até então possível parceria. Logo demonstrei interesse em mudar para Ribeirão Preto para viver essa nova experiência e, após alguns meses, ela gentilmente me deu a oportunidade de prestar a seleção do mestrado, onde fui aprovada em terceiro lugar.

Após ingresso no mestrado, iniciei as participações nas reuniões do Laboratório em Processos de Subjetivação em Saúde - LaProSUS, também coordenado pela Prof ${ }^{a}$ Carmen, onde nos encontramos juntamente com os outros membros para discutir materiais teóricos e contribuir na construção dos trabalhos que estão em andamento. Participei também de alguns eventos científicos, onde apresentei trabalhos e também pude me aprofundar em assuntos importantes para a minha pesquisa. Sob a supervisão da Prof ${ }^{\mathrm{a}}$ Carmen, realizei na modalidade de bolsista 0 estágio do Programa de Aperfeiçoamento de Ensino - PAE na disciplina Contribuições da Psicologia à Odontologia ministrada por ela na Faculdade de Odontologia de Ribeirão Preto. Durante o estágio pude participar ativamente de todas as etapas que compõem o planejamento e a execução de uma disciplina, o que me serviu para descobrir em mim um forte interesse pela docência. Ainda, o estágio me ajudou bastante com a imersão no curso de Odontologia, facilitando meu entendimento de diversas questões que emergiram nesse estudo.

Ao finalizar minha pesquisa de mestrado consigo olhar para traz, apreender a importância de cada passo dado até aqui e entender que tudo o que vivi me constituiu enquanto profissional da psicologia, pesquisadora e ser humano. Percebo que tudo 0 que relatei acrescentou em mim elementos que me possibilitaram ter um olhar mais maduro, crítico e humano no desenvolvimento desse estudo. Meu objetivo com a publicação dessa dissertação pouco tem a ver com a pretensão de apontar respostas para as inquietações que a motivaram, mas, quem sabe, possibilitar uma ampliação das discussões e reflexões que podem abrir caminhos rumo a novas formas de viver a experiência do atendimento odontopediátrico. 





\section{INTRODUÇÃO}

\subsection{História da Odontologia e o Modelo Biomédico}

O surgimento e desenvolvimento da Odontologia, que teve origem na préhistória (Rosenthal, 2001), estão intimamente ligados aos da medicina, tendo em vista que ambas nasceram na mesma época e no momento em que o homem teve contato com suas primeiras dores (Silva \& Sales-Peres, 2007). Há relatos de que o exercício da Odontologia, denominado de "Arte Dentária" antes de ser reconhecido como profissão, era associado às figuras de barbeiros e curandeiros: barbeiros que, além das atividades de barba e cabelo, também possuíam o ofício de sangradores; e curandeiros, que evocavam ao sobrenatural para resolver os problemas relacionados à saúde bucal (Ferreira, et. al., 2013).

Por volta do século XIX, a Odontologia perdeu seu caráter empírico e foi transformada em ciência pelo francês Pierre Fauchard, considerado o "Pai da Odontologia", o que garantiu maior visibilidade e respeito ao ofício. Do processo iniciado por Fauchard até os anos de 1930 ocorreu a legalização da profissão, que foi impulsionada pelo mecanismo da "diplomação universitária" no período de desenvolvimento do capitalismo. Esse acontecimento possibilitou o aumento da oferta e consumo de serviços de saúde odontológicos, criando um mercado de trabalho consistente e, ainda, um importante processo de valorização da Odontologia enquanto prática social (Ferreira et al., 2013). Ainda nesse século, a Odontologia "científica" chega à América documentada principalmente, a partir de três eventos importantes que ocorreram nos Estados Unidos: a fundação da Society of Dental Surgeons em Nova York no ano de 1834, a criação, em 1839, da primeira escola da América especializada na prática dental, a Escola de Odontologia de Baltimore, e a publicação do primeiro jornal especializado, intitulado The American Journal of Dental Science (Silva \& Sales-Peres, 2007).

Com relação ao Brasil, a Odontologia enquanto profissão teve seu início no século XVII, quando Gomes Freire de Andrade sancionou o Regimento ao Cirurgião Substituto das Minas Gerais, podendo este documento ser considerado, em parte, uma espécie de primeira legislação brasileira referente ao ofício da Arte Dentária (Cunha,1952). 
Desde então, as atividades de Arte Dentária, e outras questões relacionadas à saúde realizadas no Brasil, eram regidas pelo Cirurgião-mor e Físico-mor, autoridades sanitárias da época. Contudo, no século XVIII, a Rainha de Portugal, D. Maria I, extinguiu estes cargos para criar a Real Junta de Protomedicato, em 17 de junho de 1742 (Silva \& Sales-Peres, 2007). Este órgão, que era composto por deputados, médicos e cirurgiões aprovados com mandatos que duravam três anos, tinha como objetivo regular e fiscalizar, na metrópole e nas colônias, a atuação dos diversos agentes de assistência aos enfermos (Silva \& Sales-Peres, 2007; Viotti, 2012). Assim, passou a emitir licenças e cartas odontológicas, de caráter temporário, apenas nos casos em que havia a inexistência de médicos. Em 07 de janeiro de 1809 ocorre a extinção da Real Junta de Protomedicato e, portanto, o controle das licenças e cartas volta a ser responsabilidade do Físico-mor e do Cirurgião-mor, que foram readmitidos aos cargos (Viotti, 2012).

Ainda nesse período, dentistas franceses e americanos começaram a chegar ao Brasil. Essa movimentação favoreceu o início do desenvolvimento tecnológico e cultural da prática e pode ser considerado como os primeiros passos para 0 estabelecimento da formação profissional em Odontologia no Brasil (Silva \& SalesPeres, 2007).

A partir de então, são iniciadas manifestações para que o exercício das intervenções na área bucal fosse realizado apenas por diplomados. Estas manifestações partiram da institucionalização dos cursos de Odontologia, ainda anexos às faculdades de Medicina, pelo Decreto no 9311 de 25 de outubro de 1884 . Assim, após anos de reivindicação por parte dos diplomados em Odontologia, em 17 de janeiro de 1951, é publicada a primeira regulamentação do exercício profissional da Odontologia através da Lei oㅡ 1314 (Silva \& Sales-Peres, 2007).

Paralelo a estes acontecimentos, a Odontologia, tanto no Brasil quanto no mundo, passa por uma propagação crescente de eventos científicos e, pela formação de uma forte indústria de equipamentos, insumos, e medicamentos médicoodontológicos que acompanharam o desenvolvimento capitalista nacional. Estes acontecimentos fortaleceram ainda mais o ensino da Odontologia, que desde seu surgimento tem sido caracterizado pela abordagem tecnicista e organicista, reproduzindo em suas práticas o modelo biomédico de atenção à saúde (Ferreira et al., 2013). 
Este modelo considera que a saúde está relacionada basicamente à ausência de doenças, ou seja, valoriza os aspectos biológicos usando a química e a física para explicar tais fenômenos, assim, não se detém aos aspectos psicossociais envolvidos no processo saúde-doença. Foi inspirado na visão mecanicista que concebe o corpo humano como uma máquina complexa de partes inter-relacionadas, que não é perfeita e tem ou terá problemas que praticamente apenas os especialistas em aspectos biológicos serão capazes de detectar e intervir (Koifman, 2001; Barros, 2002). Este modelo atendeu bem às necessidades numa época em que havia um predomínio de mortes por causas infecciosas e favoreceu a evolução da ciência para que esta encontrasse a solução de muitas das doenças crônicas. Ainda, possibilitou o desenvolvimento de aparelhagens, técnicas e medicamentos capazes de salvar vidas (Koifman, 2001).

Mas, segundo Porto (1994), este modo de atenção mecanicista passou a facilitar a institucionalização dos cuidados em saúde, o aumento nos custos dos serviços e prejudicar a relação médico-paciente. Canguilhem (1990) aponta que o modelo biomédico trabalha na perspectiva da fragmentação do indivíduo em corpo e mente, sendo este um dos aspectos capazes de influenciar o afastamento entre profissionais e usuários.

Mota, Farias e Santos (2012) afirmam que o desenvolvimento das relações interpessoais é fundamental para que haja um melhor entendimento entre o profissional da saúde e o usuário. Para os autores, embora essa questão seja importante, para que uma mudança de paradigma seja alcançada é necessário ir além, ou seja, buscar desenvolver uma prática que leve em consideração a relação do profissional com o paciente e que possa oferecer um atendimento que não o dissocie das condições na qual vive. Os autores apontam, ainda, a necessidade de que estes profissionais considerem o indivíduo como um ser biopsicossocial, levando em consideração a integralidade do ser humano e não apenas sua doença e sintomatologia. Nesse contexto, a adoção de posturas mais humanizadas à prática odontológica, pode contribuir para que o dentista compreenda seus pacientes, tornando o tratamento mais eficaz e positivo.

Contudo, ressalta-se que o distanciamento do profissional em relação ao paciente tem início possivelmente ainda na graduação, já que em muitos casos os acadêmicos não são preparados para lidar com o ser humano em sua complexidade. (Guerra et. al., 2014). O estudo realizado por Moretti-Pires (2008) que teve como 
objetivo avaliar em que medida o modelo pedagógico universitário pode influenciar a formação de dentistas, enfermeiros e médicos no tocante à humanização, evidenciou que o ensino nessas áreas se dá de forma tradicional, narrativa e depositária, com experiência desumanizadora que tenderá a refletir na postura profissional do estudante. Tal fato também foi observado em outros estudos realizados em clínicasescolas da graduação, ou seja, muitos acadêmicos mantêm na atuação uma perspectiva que continua a dissociar os aspectos físicos do universo particular do paciente (Canalli et. al., 2012; Mota et. al, 2012; Guerra et. al., 2014).

A problemática também foi apontada na pesquisa realizada por Nuto et al (2006), que perceberam na prática odontológica a presença da dicotomia corpomente, onde o foco maior é dado para o desenvolvimento de habilidades técnicas e motoras. Segundo análise dos autores, os resultados revelam uma pouca capacitação dos futuros profissionais para o desenvolvimento de uma relação dentista-paciente baseada em receber, escutar, atender, orientar, encaminhar e acompanhar. Ainda, concluem que há a necessidade de que os aspectos citados sejam repensados dentro da formação do cirurgião-dentista.

Nesse contexto, algumas medidas têm sido adotadas pelos cursos de graduação visando ampliar a perspectiva de humanização na Odontologia. Por exemplo, a oferta de disciplinas que busquem ensinar aos alunos princípios voltados à humanização da prática, bem como a mudança na postura dos professores no processo ensino-aprendizagem. Ainda, a inserção dos estudantes em serviços da rede de saúde pública, através de estágios e programas de extensão, tem ajudado os alunos a entenderem o que é esperado de uma atuação mais humana, baseada nos princípios da Política Nacional de Humanização.

\subsection{Humanização em Saúde Pública e Política Nacional de Humanização} (PNH)

A Humanização do Atendimento requer a valorização de ações voltadas ao cuidado, sendo este pautado numa visão global tanto das situações quanto das pessoas nelas envolvidas. Para tal, é necessário que a equipe de saúde compreenda a necessidade de que todos os membros da coletividade, inclusive usuários, se sintam beneficiados e beneficiários. Assim, dentro das ações de atendimento humanizado, busca-se estimular a manutenção de um ambiente de cuidado humano que envolva a 
gestão, os trabalhadores e os usuários de modo que todos cuidem e sejam cuidados (Pereira et al., 2010). As práticas em Humanização foram categorizadas por Nora e Junges (2013) em três domínios a partir de uma revisão sistemática da literatura: organização e infraestrutura dos serviços básicos de saúde, o processo de trabalho e as tecnologias das relações.

No primeiro domínio estão contidos aspectos como ambiente físico e instalações, acesso aos serviços, disponibilidade de medicamentos e aparelhagem. Este domínio se divide em duas subcategorias: a primeira se refere à infraestrutura física e material dos serviços e a segunda está relacionada aos aspectos assistenciais que dificultam ou facilitam o acesso aos serviços de saúde (Nora \& Junges, 2013). A maneira como os serviços são organizados propiciam ainda a manutenção do modelo de condutas tecnicistas, o que prejudica o acolhimento e a integralidade do cuidado, pois o que se busca é a formação de profissionais que consigam manter simultaneamente ações de eficiência técnica e científica, que tenham postura ética e que respeitem a necessidade e a singularidade de cada usuário (Barbosa et al., 2013).

No domínio da organização do processo de trabalho, são apresentadas questões que se referem ao número de profissionais, à carga horária de trabalho, à remuneração, ao trabalho em equipe, ao processo de trabalho e sua fragmentação, aos momentos coletivos e à responsabilização profissional. E no domínio das tecnologias das relações têm-se o acolhimento, o estabelecimento de vínculos, a escuta, o respeito e o diálogo, considerados como tecnologias leves (Nora \& Junges, 2013). Em suma, a humanização está relacionada ao compromisso com os direitos humanos, ao acesso a serviços e ao estabelecimento de vínculos participativos e solidários da coletividade na gestão dos serviços de saúde. É o encontro dos sujeitos e das subjetividades (Casate \& Corrêa, 2012).

A Política Nacional de Humanização (PNH), também conhecida como HumanizaSUS, é a implementação do conceito de humanização nos serviços, e consiste em um programa para ofertar, no setor da saúde, um atendimento de qualidade que articule os avanços tecnológicos com o acolhimento pessoal e a melhoria dos ambientes de cuidado e das condições de trabalho dos profissionais. Assim, um dos objetivos centrais da PNH é tentar promover mudanças humanizadoras nos modos de gerir e cuidar em saúde (Brasil, 2004). Esta Política foi lançada em 2003 e desde então tem trabalhado para colocar em prática os princípios do Sistema Único de Saúde (SUS). 
Dentre as principais atividades da $\mathrm{PNH}$, destacam-se: facilitar o acesso aos serviços prestados pelo SUS (promoção da saúde, atendimento ambulatorial e hospitalar, etc.), promover uma maior resolutividade aos problemas do usuário e garantir seus direitos, promover uma gestão participativa, promover a educação permanente dos trabalhadores, valorizar a dimensão subjetiva, coletiva e social, fortalecer o trabalho multiprofissional, construir a autonomia e o protagonismo dos sujeitos e coletivos implicados na rede do SUS, e valorizar a ambiência, organizando espaços saudáveis e acolhedores (Lima \& Souza, 2010; Monteiro et al, 2012).

A desumanização, definida pela $\mathrm{PNH}$ como sendo os diversos fenômenos desagradáveis que são observados pela população em geral e profissionais, e que ocorrem dentro dos serviços de saúde, visam ser evitadas por esta política. Por exemplo: problemas com as filas; a insensibilidade dos profissionais de saúde frente ao sofrimento das pessoas; os tratamentos desrespeitosos; 0 isolamento das pessoas de suas redes sócio-familiares nos procedimentos e nas internações; as práticas de gestão autoritária; as deficiências nas condições concretas de trabalho, incluindo a degradação dos ambientes e das relações de trabalho. Pode-se dizer que os problemas decorrentes da desumanização expressam de forma concreta o modo como os processos de trabalho em saúde têm sido precariamente concebidos e organizados (Brasil, 2010).

No campo da Odontologia a adoção dos princípios da PNH é recente. Sua história aponta para uma tecnificação da prática profissional, fato este reiterado pelo documento oficial da Política Nacional de Saúde Bucal do Brasil que traz, na história da prática odontológica, a presença de aspectos como: "o biologismo (exclusão dos aspectos sociais), mecanicismo (analogia do corpo com a máquina), centralização de recursos (hospitais centrais, atenção urbanocêntrica), especialização (fracionamento do conhecimento), tecnificação do ato (associação da qualidade à tecnologia de alta sofisticação), ênfase na prática curativa (a cura incorporou mais tecnologia, mais custo) e exclusão de práticas alternativas (refutação a priori de outros métodos)." (Brasil, 2006).

Logo, com base na literatura revisada, percebe-se que para a humanização de profissionais, serviços e práticas no campo da Odontologia não é suficiente apenas adotar os princípios e diretrizes da PNH. É necessário que haja uma conscientização maior acerca da importância da formação básica desses profissionais para que estes se comprometam com a defesa da dignidade humana. Assim, a humanização dos 
serviços em Odontologia não é uma tarefa fácil, ainda, o acompanhamento do processo de apropriação do conhecimento via experiência deve refletir na prática profissional.

\subsection{Humanização em Odontopediatria e o Atendimento no Contexto da Clínica-escola}

A humanização no campo da Odontologia ganha relevância tendo em vista a evolução científica e técnica dessa profissão marcada por uma ênfase nos aspectos técnicos. Destaca-se a necessidade de que o cirurgião-dentista consiga transcender a promoção de saúde bucal para acolher o indivíduo que sofre, assim, a atuação do profissional desta área oscila no equilíbrio entre a habilidade técnica, a formação científica e a visão humanista da promoção da saúde (Guerra et. al. 2014). Deste modo, hoje é possível entender a humanização na Odontologia alicerçada no tripé acolhimento e direito do usuário, prática odontológica e construção de um modelo organizacional humanizado.

A consulta odontológica, por envolver um ato de intimidade, constitui para o paciente uma experiência emocional que poderá trazer implicações nas práticas em saúde bucal. Logo, há a necessidade da conscientização de que o exercício da Odontologia deve ser revestido de um compromisso ético que vá além da busca por recuperar a função, a estética e o alívio da dor do paciente. Considera-se, ainda, que com a adoção de posturas mais humanas e tranquilas é possível que o paciente responda de forma cooperativa, principalmente se este for criança (Guerra et. al. 2014).

Os princípios que norteiam o cuidado à criança abrangem ações e práticas intersetoriais que facilitam aos profissionais de diversas áreas atuarem no desenvolvimento de ações que incluam: acolhimento, acesso universal, assistência integral, equidade e participação familiar. Tais aspectos contribuem para a manutenção de um modelo de assistência que favoreça o acompanhamento e a aproximação das famílias e das crianças junto aos profissionais de saúde, construindo assim um vínculo terapêutico fundamental para a prestação de um atendimento humanizado (Monteiro et al, 2012).

Monteiro et. al. (2012) apontou a necessidade de que o odontopediatra se mantenha atualizado em estratégias que auxiliem seus pacientes a lidar com as 
demandas emergentes do tratamento odontológico. Afirmam, ainda, que tanto antes quanto durante o tratamento é esperado que o dentista esteja apto a identificar os principais indicadores do desenvolvimento da criança e perceber os comportamentos apresentados durante a exposição ao ambiente de cuidados odontológicos.

A Academia Americana de Odontopediatria - AAPD (2015) escreveu um manual onde apresenta diretrizes para orientar os dentistas a lidar com os pacientes pediátricos. Neste guia, a AAPD ressalta que o comportamento dos membros da equipe odontológica é a principal ferramenta que pode ser usada para orientar a criança. Aspectos como atitude, linguagem corporal e habilidades de comunicação (que no atendimento odontopediátrico são expressas principalmente através do diálogo, tom de voz, expressão facial e linguagem corporal) são fundamentais para facilitar que a criança tenha uma experiência positiva na consulta, e também para conquistar sua confiança e de seu acompanhante. Aumentar o vínculo afetivo entre profissional e paciente é essencial para o bom andamento do tratamento odontológico.

Segundo Mota, Farias \& Santos (2012), demonstração de empatia por parte do dentista, seu respeito às queixas e sentimentos do paciente e o esclarecimento dos procedimentos que serão realizados, podem minimizar e até suprimir a ansiedade do paciente. Ainda, segurança, confiança, tranquilidade e serenidade são aspectos do paciente que devem ser encorajados pelo profissional durante as consultas. A importância desses aspectos também foi referida em pesquisa realizada por Raldi et. al. (2003) com alunos e pacientes de clínicas-escolas, que apontou o bom atendimento como uma das principais expectativas dos usuários em relação aos alunos.

A respeito do atendimento odontológico nas clínicas-escolas, tem-se que seu objetivo é atender a necessidade de formação e treinamento, tanto prático quanto técnico, dos alunos, abrangendo também os aspectos éticos que versam entre suprir a demanda dos usuários do serviço e formar profissionais que sejam comprometidos com a ética e o atendimento humanizado (Scalioni et. al., 2008). Nesse contexto, o aluno lida com as demandas da realização de seus primeiros trabalhos, executando procedimentos odontológicos sob a orientação e supervisão dos docentes que, por sua vez, avaliam seu desempenho através destas atividades (Cardoso \& Loureiro, 2008).

Na clínica-escola o supervisor exerce atividade pedagógica dentro do ambiente de trabalho, o que é de grande importância, pois oferece ao aluno situações que lhe 
permitam construir e reconstruir conhecimentos (Forte et. al., 2015). Em estudo realizado, Botti e Rego (2010) relatam, através dos resultados obtidos, que é papel do supervisor: planejar, controlar, guiar, estimular o raciocínio e a postura ativa, analisar o desempenho, aconselhar e cuidar do crescimento profissional e pessoal, observar e avaliar o estudante na execução de suas atividades e atuar na formação moral. Assim, é possível perceber que as atribuições do supervisor na clínica-escola vão além de apenas transmitir conhecimentos técnicos.

Klatchoian (1993, apud Cardoso \& Loureiro, 2008) afirma que os atendimentos odontológicos que ocorrem nas instituições têm a tendência de supervalorizar a produtividade e a atuação do profissional, considerando pouco relevante os sentimentos das crianças e dos cirurgiões-dentistas, o que facilita a ocorrência de práticas e atitudes autoritárias. Nesse contexto, a relação existente entre dentista e paciente torna-se mais impessoal e o profissional tende a relegar a individualidade do paciente a segundo plano, visto que o vínculo principal é aquele existente entre paciente e instituição, onde muitas vezes são as regras desta que devem ser priorizadas.

Um processo de trabalho humanizado não pode ser puramente assistencial, pois requer do cirurgião dentista a tentativa de modificar a forma como se relaciona com pacientes e colegas. Buscar escutar ativamente o que as pessoas têm a dizer e tentar compreender aquilo que não foi verbalizado é algo que pode contribuir para o sucesso do tratamento (Canalli, et. al., 2012). Nesse sentido, estudos apontam que o processo ensino-aprendizagem vivenciado nas faculdades pode ajudar ou atrapalhar no desenvolvimento dessas capacidades (Raldi et. al., 2003; Nuto et. al., 2006; Lazzarin et. al. 2007).

\subsection{Processo Ensino-Aprendizagem em Odontologia}

Historicamente, a formação em Odontologia tem se baseado na transmissão do conhecimento com foco no desenvolvimento de habilidades técnicas, nas doenças bucais e na clínica privada. Assim, para o ensino de qualidade nesta área, é importante que se considere o desenvolvimento social, econômico e cultural como um todo para que um processo novo de educação seja iniciado (Forte et. al., 2015).

$\mathrm{Na}$ Europa diversas mudanças foram propostas na formação de cirurgiõesdentistas a partir da Declaração de Bolonha, que objetivou estabelecer competências 
necessárias aos egressos das faculdades de Odontologia do continente, dentre as quais se destacam: comunicação, profissionalismo, análise crítica, habilidades interpessoais, planejamento e diagnóstico clínico. No Brasil, as exigências que surgiram a partir das Diretrizes Curriculares Nacionais (DCN) sinalizaram para 0 desafio de desenvolver uma formação mais qualificada, que seja voltada à prática, com a finalidade de abordar os sujeitos, famílias e comunidade dentro de seu contexto socioeconômico e cultural, respeitando os valores, hábitos e costumes, e isso exige mudanças na forma de exercer a docência. (Forte et. al., 2015).

As normas das DCN para os Cursos de Graduação em Odontologia apontam, como esperado do egresso/profissional, um perfil que contemple qualidade técnica e humanização, e define o cirurgião dentista como um profissional: "generalista, humanista, crítico e reflexivo, para atuar em todos os níveis de atenção à saúde, com base no rigor técnico e científico. Capacitado ao exercício de atividades referentes à saúde bucal da população, pautado em princípios éticos, legais e na compreensão da realidade social, cultural e econômica do seu meio, dirigindo sua atuação para a transformação da realidade em benefício da sociedade" (Brasil, 2002, p.10).

Nuto et al (2006) ao desenvolveram um estudo em quatro cursos de Odontologia no Nordeste do Brasil, com o objetivo de analisar os aspectos éticos e humanos envolvidos no processo ensino-aprendizagem, levantaram alguns problemas existentes na formação destes profissionais. Os autores apontaram a existência de uma relação autoritária entre professor e estudante, que pode desencadear uma baixa autoestima, capaz de impactar no desenvolvimento afetivo do aluno consigo mesmo e também com colegas e pacientes.

Segundo Deslandes (2004) "obviamente não se muda uma cultura de assistência unicamente com capacitações dirigidas aos profissionais. Mas, certamente, um investimento sério na formação (inclusive desde a graduação) pode, de fato, fortalecer ideias outrora consideradas utópicas ou fora do âmbito e do papel da assistência (p.09)".

Assim, o contato mais próximo com a realidade da profissão e as novas ferramentas pedagógicas embasadas em metodologias ativas exigem habilidades do docente para a mediação do processo ensino-aprendizagem do aluno, pois o conhecimento é construído pelo sujeito através da sua relação com o outro e com o mundo (Ferreira et. al., 2008). 
Com base na literatura apresentada é possível perceber que a Odontopediatria exige que o aluno disponha de diversos recursos técnicos e pessoais para desempenhar bem sua função. É esperado, por exemplo, que o aluno tenha conhecimento técnico para atuar na Clínica-escola, que o execute com sucesso para ser bem avaliado, que utilize uma abordagem humanizada em suas práticas e relações pessoais, enfim, muitas são as demandas existentes no processo ensinoaprendizagem. Diante de um cenário com tantas exigências aos estudantes, nota-se a existência de um ambiente com relações profissionais e pessoais que não facilitam o sucesso das estratégias que visam a humanização das práticas em Odontopediatria.

A humanização em Odontopediatria tem ganhado visibilidade na literatura nacional e internacional devido à importância de se reproduzir nos atendimentos um ambiente facilitador às práticas que amenizem os impactos causados pelo processo saúde-doença, tanto para usuários quanto para profissionais (Scalioni et. al., 2008; Canalli et. al., 2012; AAPD, 2015). Apesar de todos os esforços voltados para a melhoria na formação e atuação dos profissionais, dos serviços prestados e da forma destes lidarem com a subjetividade dos pacientes, a literatura refere que estes aspectos na Odontologia ainda não estão dentro de uma abordagem humanística aceitável. (Nuto et. al., 2006; Lazzarin et. al., 2007; Mota et. al. 2012).

Tendo em vista que a humanização dos atendimentos em Odontologia é um aspecto tão importante quanto a capacidade técnica do profissional (Mota et. al., 2012), esta pesquisa se justifica na medida em que aponta, com base na literatura, a importância de analisar os fenômenos que influenciam na adoção ou não de posturas, práticas e relações humanizadas no atendimento odontopediátrico, com foco no ensino-aprendizagem. Considera-se que compreender os aspectos que estejam relacionados às problemáticas existentes pode facilitar na identificação da gênese dos problemas e, assim, intervenções para a melhoria do serviço e das vivências podem ser desenvolvidas a partir de apontamentos científicos. Também, poderá contribuir para que ações mais direcionadas e possivelmente mais eficazes sejam desenvolvidas, no intuito de promover a humanização.

$\mathrm{Na}$ tentativa de entender melhor estes aspectos e contribuir para mudanças, diversos autores apontam que a modificação do processo de ensino-aprendizagem é um ponto de partida importante para avançar nessas questões (Raldi et. al. 2003; Nuto et. al., 2006; Lazzarin et. al. 2007). Assim, compreender melhor como se dá a 
experiência do aluno no seu período de formação pode ser de grande valia para identificar questões que contribuem para a formação de profissionais pouco comprometidos com os aspectos humanísticos da profissão. 


\section{OBJETIVOS}

\subsection{Objetivo geral}

Compreender as vivências dos graduandos de Odontologia, durante sua formação acadêmica, frente ao tratamento Odontopediátrico em uma Clínica-escola bem como os aspectos relacionados à humanização do serviço prestado e das relações existentes nesse contexto.

\subsection{Objetivos específicos}

2.2.1. Investigar, a partir dos relatos dos estudantes, como se deu a formação recebida na Faculdade de Odontologia para a realização do atendimento à criança.

2.2.2. Investigar como se deu a supervisão/orientação dos docentes/ profissionais, na perspectiva dos alunos, para a realização de atividades práticas na Clínica-escola de Odontopediatria.

2.2.3. Investigar como os graduandos compreendem os aspectos relacionados à humanização em Odontopediatria, nas etapas vivenciadas no processo de ensino-aprendizagem e nas relações construídas nesse contexto. 
MÉTODO 


\section{MÉTODO}

Esta investigação se caracteriza como um estudo transversal, descritivo, com coleta e análise de dados numa abordagem qualitativa.

A escolha pela abordagem qualitativa se deu pensando na adequação de suas especificidades com os objetivos propostos pelo estudo, visto que segundo Turato et.al. (2008) essa abordagem é bem aplicada no "estudo da história, das relações das representações, das crenças, das percepções e das opiniões que são produtos das interpretações que o ser humano faz acerca de como vivem, constroem seus artefatos e a si mesmos, sentem e pensam". Ainda, quando aplicada nas ciências humanas, a pesquisa qualitativa não busca por uma explicação dos fenômenos em si, mas entender seu significado individual ou coletivo na vida das pessoas (Turato, 2005).

\subsection{Aspectos éticos}

Por se tratar de uma pesquisa envolvendo seres humanos, todos os aspectos éticos foram levados em consideração. O projeto foi aprovado, em primeira instância, pelo Comitê de Ética da Faculdade de Filosofia, Ciências e Letras de Ribeirão Preto - USP em 20/10/2016 sob o CAAE o 60219816.6.0000.5407. Também, foram adotados todos os procedimentos básicos e éticos de respeito aos voluntários e à instituição, de acordo com as Resoluções número 466/12 e 510/16 sobre "pesquisa envolvendo seres humanos" do Conselho Nacional de Saúde, do Ministério da Saúde (Brasil, 2012, 2016).

Os participantes do estudo foram esclarecidos previamente sobre os procedimentos e objetivos da pesquisa. A pesquisadora explicou questões como a ausência de danos significativos e riscos decorrentes da participação, a possibilidade de desistência a qualquer momento em que o participante julgasse necessário sem que isso implicasse qualquer ônus, e também a garantia do sigilo no que se refere à identificação. Aqueles que concordaram com o exposto e aceitaram participar do estudo assinaram o termo de consentimento livre e esclarecido e receberam uma via do documento. 


\subsection{Constituição do Corpus}

\subsubsection{Contexto do Estudo}

Este estudo foi realizado em uma Faculdade de Odontologia do Estado de São Paulo. O curso de Odontologia desta Faculdade ocorre na modalidade presencial, turno integral, com duração total mínima de dez semestres e máxima de quinze semestres e carga horária de 5.340 horas. Anualmente, são oferecidas 80 vagas para ingresso e, ao concluir o curso, é conferido ao profissional o título de CirurgiãoDentista.

Durante esse percurso, os alunos têm contato com todas as áreas de atuação, através de disciplinas teóricas, práticas e teórico-práticas que objetivam ofertar um ambiente onde possam realizar procedimentos odontológicos em pacientes de todas as faixas etárias. Ainda, nas Clínicas-escola da Faculdade, onde os alunos desempenham a etapa prática das disciplinas, os procedimentos estudados são realizados em membros da comunidade geral, proporcionando a essa população o cuidado em saúde bucal. Esses atendimentos são realizados sob a supervisão de Professores membros da Faculdade e alunos da Pós Graduação, que orientam e avaliam os alunos durante o desempenho dessa função.

Acerca de como ocorrem às disciplinas de Odontopediatria, foco desse estudo, a pesquisadora obteve as informações a partir das ementas atualizadas das mesmas. Tais disciplinas são ofertadas em dois semestres (Odontopediatria I e II) com duração total de um ano e objetiva-se: formar profissionais capacitados a realizar atendimento odontológico de crianças de 0 a 12 anos, a partir do modelo biopsicossocial, envolvendo técnicas de manejo do comportamento; possibilitar aos estudantes 0 exercício de atuar na prevenção em saúde, bem como o contato e atendimento de diversos acometimentos em saúde bucal; promoção de um espírito crítico e investigativo para a construção do conhecimento dentro do processo de aprendizagem.

As disciplinas são teórico-práticas e acontecem da seguinte forma: as aulas teóricas foram compostas por aulas expositivas dos conteúdos, com a utilização de recursos audiovisuais, fornecimento de roteiros e referências bibliográficas para orientar os estudos e, ainda, realizou-se atividades através de espaços virtuais. Para as aulas práticas, os alunos foram divididos em grupos de, aproximadamente, quatro 
duplas, onde cada grupo foi orientado por um docente da disciplina em sistema de rodízio a cada dois meses. Cada dupla atendeu dois pacientes de diferentes faixas etárias e gênero, sendo responsável pela realização de anamnese, exame clínico e radiográfico, estruturando o plano de tratamento e executando todos os procedimentos preventivos, restauradores, endodônticos e cirúrgicos indicados. Ainda, atenderam pacientes que já tiveram seus tratamentos concluídos para fins de controle e manutenção da saúde bucal. Foram realizadas também atividades educativas com a comunidade.

Sobre os critérios para obtenção de notas, os estudantes foram avaliados a partir de atividades teóricas e práticas. No módulo teórico das disciplinas, os estudantes foram submetidos a avaliação continuada acerca dos assuntos ministrados, por meio de provas semanais e atividades em ambiente virtual. Ainda, foram realizadas duas provas no decorrer do semestre e a nota final dessa etapa foi obtida através de média geométrica das notas das provas.

No módulo prático, a avaliação foi feita diariamente na Clínica-escola através do cumprimento dos trabalhos realizados, sendo estes pontuados de 0 a 10. Tais trabalhos consistiram em: organização do instrumental e do campo de trabalho, pontualidade ao chegar e sair da clínica, uniformização, habilidade de manejo do paciente, desempenho no atendimento e a qualidade do trabalho executado. A nota final das atividades práticas foi realizada através da média aritmética de todas as notas obtidas ao longo de cada semestre, podendo esta ser alterada em função do número e da quantidade de trabalhos realizados. A nota final de cada disciplina consistiu no cálculo da média entre as etapas teórica e a prática.

\subsubsection{Caracterização dos Participantes}

Participaram da pesquisa estudantes universitários do quarto ano do curso de Odontologia, de uma faculdade pública do estado de São Paulo, que prestavam atendimento Odontopediátrico na Clínica-escola da instituição. A motivação para a escolha de estudantes do quarto ano foi que os mesmos já tinham passado pela disciplina de Odontopediatria I e estavam no final da Disciplina de Odontopediatria II, ou seja, estavam vivenciando a prática clínica com crianças, e ainda por estarem mais próximos à conclusão do curso, já tendo percorrido grande parte da grade curricular. 
Desse modo, pôde-se ter um panorama de como se deu a formação e as vivências destes estudantes na área de Odontopediatria.

O estudo contou com a participação de dez estudantes todos do quarto ano do Curso de Odontologia, sendo cinco homens e cinco mulheres, com idades entre $22 \mathrm{e}$ 27 anos. O número de participantes foi determinado pelo tipo de amostragem não probabilística, em que os primeiros participantes indicaram os próximos, e assim por diante. Essa técnica foi definida por Biernacki e Waldorf (1981) como snowball, conhecida no Brasil como "Bola de Neve" ou "Amostragem em Bola de Neve". A pesquisadora iniciou as transcrições das entrevistas juntamente com a coleta dos dados e isso permitiu a observância do momento em que a fala dos respondentes começaram a se repetir, coincidindo com o que os novos participantes falavam. Nesse momento, considerou-se atingido o ponto de saturação (Minayo, 2004) e a fase de entrevistas foi interrompida. Ressalta-se que os nomes utilizados neste estudo são fictícios, visando preservar a identidade dos participantes.

\subsubsection{Procedimentos de Coleta}

A coleta de dados foi realizada durante os meses de novembro e dezembro de 2016. Considerando os critérios de inclusão descritos anteriormente, os participantes foram, inicialmente, convidados coletivamente ao final de uma aula em que a pesquisadora se fez presente para divulgar o estudo e disponibilizou uma lista onde os interessados informaram email e telefone para contato. A partir disso, aqueles que declararam interesse foram contatados e as entrevistas foram marcadas. Ainda, após indicação de colegas, alguns participantes foram convidados pela pesquisadora. Esses últimos foram abordados na Clínica-escola de Ondontopediatria.

Para o procedimento de coleta, a pesquisadora marcou horário individual com cada participante, na própria Faculdade para responderem a uma entrevista semiestruturada, face-a-face e com duração aproximada de sessenta minutos, realizada em salas de aula da própria Instituição de Ensino Superior. Na ocasião da entrevista, a pesquisadora leu para cada participante o Termo de Consentimento Livre e Esclarecido - TCLE, esclareceu possíveis dúvidas e, feito isso, os estudantes assinaram a via que consta nos arquivos da pesquisadora e ficaram com outra para si. Após consentirem a participação bem como a áudio gravação da entrevista, a coleta foi iniciada, sendo utilizado um aparelho gravador de voz, caneta e papel. 


\subsubsection{Instrumento}

O instrumento da coleta de dados foi uma entrevista semiestruturada composta por quatro questões norteadoras. A medida que os participantes falavam, a pesquisadora assumiu uma postura investigativa acerca das temáticas que eram mais relevantes para os objetivos deste estudo, explorando mais profundamente as falas que transcorriam nesse sentido.

A primeira questão norteadora foi "Me conta um pouco sobre a sua formação acadêmica para atuar em Odontopediatria?”. Essa questão teve como objetivo facilitar ao participante discorrer sobre sua formação (aspectos teóricos, práticos, estrutura física, professores, dentre outras questões que surgiram no discurso) e o quanto se sentiu preparado para atuar frente às demandas da área.

A segunda questão foi "Me conta agora como foi a supervisão/orientação que você recebeu dos profissionais durante sua atuação na Clínica-escola? Você pode agora falar um pouco do quanto acha que este acompanhamento o ajudou para atuar em Odontopediatria?". Os estudantes discorreram sobre como percebem o trabalho realizado pelos profissionais (aspectos técnicos, teóricos, humanísticos, relações construídas, dentre outros) e os sentimentos envolvidos nesta relação de trabalho, sendo estes relacionados também à equipe, ao paciente, ao professor supervisor e família/acompanhante.

A terceira questão da entrevista foi "Me conta um pouco o que você sabe e pensa sobre a humanização em Odontopediatria”. O estudante foi chamado a falar sobre como compreende os aspectos relacionados à humanização na área (em que consiste, a importância, as diretrizes, dentre outras questões) e se aplica estes princípios em seus atendimentos.

A quarta pergunta foi: "Você poderia me relatar um atendimento que tenha marcado sua trajetória na Clínica-escola? " Nesse momento, os estudantes foram convidados a relatar uma experiência, algum atendimento que tenha ficado mais forte em suas memórias. É importante ressaltar que a pesquisadora não especificou se as experiências deveriam ser positivas ou negativas, essa escolha ficou a critério dos alunos. 


\subsubsection{Percurso de Análise do Corpus}

A Análise do Corpus foi realizada com base no método de Análise de Conteúdo Temática proposta por Bardin (1977/2011), que consiste em um "conjunto de técnicas de análise da comunicação, visando obter, por procedimentos sistemáticos e objetivos de descrição do conteúdo das mensagens, indicadores que permitam a inferência de conhecimentos relativos ao modo como tais mensagens foram produzidas, transmitidas e recebidas" (p.48).

Essa modalidade de análise é composta por três etapas. A primeira delas é a Pré-análise, que consiste na leitura flutuante do material coletado, proporcionando ao pesquisador contato exaustivo com os textos e com seu conteúdo. Esta é a fase de constituição da discussão, organizando o material na tentativa de responder às normas de validade: exaustividade, homogeneidade, representatividade e pertinência.

A segunda etapa é a de Exploração do Material, que consiste na codificação do material coletado e é entendida como o processo de transformação dos dados, realizada através de recortes e agregação, o que permite que seja atingida uma representação do conteúdo capaz de esclarecer o pesquisador ao que se refere às características do texto. A terceira e última etapa, chamada de Tratamento dos resultados e interpretação, é onde os resultados brutos são categorizados e inferências são realizadas a partir de recortes dos agrupamentos elaborados, ou seja, os dados categorizados serão interpretados para que possam ser analisados (Bardin, 1977/2011). 
ANÁLISE DO CORPUS 


\section{ANÁLISE DO CORPUS}

A partir da análise das entrevistas, os resultados foram divididos em dois eixos visando uma apresentação mais didática. O primeiro eixo foi intitulado "Dificuldades na Clínica-escola: do saber técnico às vivências na clínica" e composto pelos sub eixos "Especificidades do atendimento à criança na Clínica-escola", "Complexidades nas relações com os acompanhantes" e "Desafios na articulação entre formação teórica e a prática do atendimento à criança". O segundo eixo foi intitulado " $A$ Humanização nas Práticas da Clínica-Escola: percepções, vivências e desafios" e foi composto pelos sub eixos "A Humanização na Prática Odontopediátrica" e "Dificuldades e Desafios para a Humanização dos Atendimentos na Clínica-escola". Abaixo, segue quadro descritivo acerca dos Eixos de Análise que compõem o Corpus da pesquisa:

\begin{tabular}{|l|l|}
\hline \multicolumn{1}{|c|}{ Eixos } & \multicolumn{1}{|c|}{ Sub Eixos } \\
\hline & $\begin{array}{l}\text { 4.1.1. Especificidades do atendimento à criança } \\
\text { na Clínica-escola }\end{array}$ \\
$\begin{array}{l}\text { 4.1. Dificuldades na Clínica-escola: do } \\
\text { saber técnico às vivências na clínica }\end{array}$ & $\begin{array}{l}\text { 4.1.2. Complexidade nas relações com os } \\
\text { acompanhantes }\end{array}$ \\
& $\begin{array}{l}\text { 4.1.3. Desafios na articulação entre formação } \\
\text { teórica e a prática do atendimento à criança. }\end{array}$ \\
\hline $\begin{array}{l}\text { 4.2. Humanização nas Práticas da Clínica- } \\
\text { escola: percepçôes, vivências e desafios }\end{array}$ & $\begin{array}{l}\text { 4.2.1. A Humanização na Prática } \\
\text { Odontopediátrica }\end{array}$ \\
& $\begin{array}{l}\text { 4.2.2. Dificuldades e Desafios para a } \\
\text { Humanização dos Atendimentos na Clínica-escola }\end{array}$ \\
\hline
\end{tabular}

Quadro 1: Apresentação dos Eixos de Análise do Corpus. 


\subsection{Eixo I: Dificuldades na Clínica-escola: do saber técnico às vivências na clínica}

Nesse eixo de análise foram reunidos os relatos dos estudantes, sobre dificuldades vivenciadas na Clínica-escola de Odontopediatria, que apresentaram subsídios para a compreensão do processo de inserção nas atividades de atendimento e das estratégias que são utilizadas para integrar e articular os conhecimentos teóricos aprendidos em sala de aula com as situações de imprevisibilidade, inerentes ao fazer clínico.

A análise de conteúdo permitiu identificar a natureza dessas dificuldades que estão relacionadas às especificidades do atendimento à criança, à mobilização de emoções no aluno causada pelo atendimento e lacunas no processo de ensino aprendizagem no que se refere ao manejo do atendimento infantil e das relações implicadas nesses atendimentos. Nesse sentido, para melhor apresentação e discussão dos dados, foram criados três sub eixos, a saber: "Especificidades do atendimento à criança na Clínica-escola; Complexidade nas relações com os acompanhantes; Desafios na articulação entre formação teórica e a prática do atendimento à criança.

\subsubsection{Especificidades do atendimento à criança na Clínica-escola}

O atendimento odontopediátrico requer conhecimentos específicos para identificar e lidar com as diferentes variantes comportamentais particulares de cada criança e da fase do desenvolvimento na qual ela se encontra (Moraes et. al., 2004). É esperado do profissional que este ofereça um atendimento integral e humanizado, baseado na corresponsabilização do cuidado e focado no paciente (Brasil, 2004; 2008).

Ressalta-se que a atuação nesse contexto demanda dos estudantes um repertório de estratégias que possa auxilia-los na oferta desse cuidado. Nesse sentido, esse sub eixo trata das especificidades presentes no atendimento à criança, onde é esperado que algumas dificuldades surjam, sejam elas relacionadas à falta de experiência desses graduandos ou até mesmo à situações próprias desse contexto de atuação. 
Nesse sentido, Ana e Carlos relataram algumas especificidades relacionadas ao contato inicial e à formação de vínculo com as crianças atendidas na clínica:

"Ah, com as crianças no começo foi um pouco difícil, por que você tem que adequar a criança a receber o tratamento... e quando elas vêm pela primeira vez, elas ficam assustadas, com medo, ansiosas. Então você tinha que demonstrar, tinha que mostrar tudo o que você tinha que fazer, assim, colocava na mão da criança... você falava 'Olha, isso aqui a gente vai usar pra tirar o bichinho da boca... que o bichinho tá fazendo caquinha ali na boca, a gente tem que tirar!'... Então tem que ser tudo de uma maneira bem lúdica pra criança!"

(Ana, estudante)

"A gente tem que sempre procurar o conforto da criança, a confiança da criança, antes de mais nada. Antes de qualquer outro procedimento que a gente vá fazer a gente tem que procurar o bem estar da criança. Então, outras clínicas a gente acaba não levando tanto em consideração o bem estar do paciente. A gente leva mais o bem estar nosso pra gente conseguir fazer o tratamento mais rápido. E lá na Odontopediatria, não! $A$ gente pode demorar um semestre pra tratar... pra tirar uma cárie, mas a gente tem que fazer isso de um jeito que a criança se sinta confortável e não tenha problema."

(Carlos, estudante)

Ana relatou que sua dificuldade inicial nos atendimentos se deu devido à necessidade de acolher as crianças e ajudá-las no desenvolvimento de uma propensão à colaboração com o tratamento que irão receber, que envolve não apenas o contato com o aluno, mas também com as tecnologias utilizadas (vestuário, equipo, materiais utilizados em procedimentos invasivos, entre outros), e que são estranhos ao universo das experiências infantis. Ainda, baseada em sua percepção sobre o estado emocional que a maioria delas apresenta quando chegam pela primeira vez na clínica, descrito como "assustadas", "com medo e ansiosas”, sua preocupação é direcionada para a melhoria da ambientação das crianças com os vários recursos presentes no tratamento odontológico. A estudante descreve para a criança, de forma lúdica, as intervenções que fará e refere o empenho na utilização de estratégias que facilitem a interação com a criança e sua compreensão sobre os procedimentos, utilizando também como estratégia a adequação da linguagem.

Voltando o olhar para a condução do atendimento por parte dos Odontopediatras, a Academia Americana de Odontopediatria - AAPD (2015) escreveu um manual onde apresenta diretrizes para orientá-los nesse sentido. Neste guia, a AAPD ressalta que o comportamento dos membros da equipe odontológica é a principal ferramenta que pode ser usada para orientar a criança. Aspectos como 
atitude, linguagem corporal e habilidades de comunicação (que no atendimento odontopediátrico são expressas principalmente através do diálogo, tom de voz, expressão facial e linguagem corporal) são fundamentais para facilitar que a criança tenha uma experiência positiva na consulta, e também para conquistar sua confiança e de seu acompanhante. Aumentar o vínculo afetivo entre profissional e paciente é essencial para o bom andamento do tratamento odontológico.

Partindo desses pressupostos, pode-se encontrar no recorte da fala de Ana a descrição de atitudes que parecem estar alinhadas com as Diretrizes propostas pela AAPD. A estudante relatou algumas manifestações de comportamento das crianças que permitiram identificar qual a melhor forma de abordar o paciente durante 0 atendimento. Ana considerou o medo e a ansiedade de seus pacientes e pautou seus atendimentos numa abordagem que partia da ambientação das crianças na Clínicaescola, fazendo com que elas se sentissem mais seguras e capazes de colaborar com 0 atendimento.

Outra questão a ser discutida é a articulação, por parte dos alunos, entre a teoria e a prática de alguns princípios da humanização do atendimento a partir da valorização da formação de um vínculo de confiança com as crianças, em detrimento de das pressões que sofrem como, por exemplo, a necessidade de um bom desempenho acadêmico e o foco na excelência técnica, que estão presentes na atuação na clínica-escola. Carlos aponta a especificidade do atendimento à criança que necessita de atenção, de cuidado e, portanto, mais tempo para a execução do tratamento, quando comparado ao adulto.

Segundo Mota, Farias \& Santos (2012), a demonstração de empatia por parte do dentista, seu respeito às queixas e sentimentos do paciente e o esclarecimento dos procedimentos que serão realizados, podem minimizar e até suprimir a ansiedade do paciente. Ainda, segurança, confiança, tranquilidade e serenidade são aspectos do paciente que devem ser encorajados pelo profissional durante as consultas. A importância desses fatores também foi referida em pesquisa realizada por Raldi et. al. (2003) com alunos e pacientes de clínicas-escolas, que apontou o bom atendimento como uma das principais expectativas dos usuários em relação aos alunos. Monteiro et. al. (2012) apontaram a necessidade de que o Odontopediatra se mantenha atualizado em estratégias que auxiliem seus pacientes a lidar com as demandas emergentes do tratamento odontológico. Afirmam, ainda, que tanto antes quanto 
durante o tratamento é esperado que o dentista esteja apto a identificar os principais indicadores de desenvolvimento da criança e perceber os comportamentos apresentados durante a exposição ao ambiente de cuidados odontológicos.

Nesse contexto, ao retomar a fala de Carlos em que ele afirma que "A gente tem que sempre procurar o conforto da criança, a confiança da criança antes de mais nada (...) a gente tem que procurar o bem-estar da criança" (sic), é possível identificar a busca por uma atuação empática com relação às crianças, visto que o estudante parece considerar as especificidades desses pacientes durante sua prática. Ele inclusive compara com o atendimento aos adultos, apontando um cuidado maior com as demandas afetivas dos pacientes pediátricos, o que parece configurar uma sensibilidade referente ao tratamento diferenciado que se faz necessário nesse contexto.

Nas experiências na clínica-escola, também puderam ser identificadas dificuldades relacionadas ao caráter de imprevisibilidade do comportamento infantil e das singularidades do vínculo, que escapam aos protocolos de condutas nos quais alguns estudantes apoiam sua prática. O relato de Laura é ilustrativo tanto das dificuldades enfrentadas, quanto das implicações dessas para seu estado emocional:

(...) teve uma criança que ela não se comunicava, então tipo assim ela não era de chorar, não era de demonstrar que tava sofrendo, mas ela não falava! Ela não falava um piu, tipo assim, nada, nada, nada! Então essa daí foi difícil! Um difícil diferente, assim, acho que não é bom que a criança não se comunique assim, sabe?! É pior às vezes, eu acho. É melhor ela falar 'ah não, tá doendo!', chorar por que tá doendo do que ela não falar nada! Nada. Não se comunicar... Fico totalmente impossibilitada de ajudar, sabe?! Não tem como eu ajudar! Não tem como eu consolar. Então eu não tinha o que fazer! Eu me sentia impossibilitada de ajudar ele. Isso é horrível, né, por que a gente quer ajudar, a gente tá ali pra ajudar! Então, nossa! Isso foi horrível! Nossa, mas é muuuita angústia! Você não tem noção! Eu saía da cadeira e falava 'Professora, ele não conversa comigo. Eu vou ficar louca!' (risos), ele não fala nada, ele não fala se tá doendo, ele não fala nada, nossa! É muito angustiante. E daí a mãe ficava atrás dele e ele só respondia fisicamente, quê com verbal ele não falava nada!

(Laura, estudante)

Laura descreve uma situação em que a criança não se comunicava verbalmente com ela e considera que seria melhor que o paciente externalizasse seus desconfortos através da fala ou do choro do que sua quietude durante todo o atendimento. A estudante se descreveu como bastante angustiada frente à situação, visto que ela se considerava incapaz de ajudar a criança devido à falta de 
comunicação verbal, que não permitia sua compreensão sobre as necessidades de seu paciente, com relação ao alívio de dor, e qual seria a melhor forma de intervir.

O relato de Laura ressalta o quanto a falta de comunicação verbal com a criança a deixa apreensiva. Isso mobilizou nela uma série de sentimentos negativos diante do imprevisto. Reconhece sua impotência diante da situação, mas não a singularidade da criança e o seu despreparo para lidar com a mesma. Por mais que a estudante possa ter sido preparada para lidar com esse tipo de situação, a angústia que permeou sua vivência nesse momento pode ter influenciado na limitação de seu repertório de estratégias de atuação. Lidar com a imprevisibilidade do atendimento infantil requer, além de preparo teórico, vivências que ajudem os profissionais em formação a elaborar suas emoções e também uma supervisão que acolha essas dificuldades.

Pode-se pensar acerca da importância de uma supervisão presente durante esse atendimento, onde o professor/supervisor pudesse dar à aluna um suporte que possivelmente a fizesse sentir um pouco mais segura diante dessa situação e a tranquilizasse para pensar uma melhor forma de atuação diante da dificuldade enfrentada. Também, o compartilhamento de experiências anteriores entre professor e aluna poderia tê-la ajudado a pensar estratégias que facilitassem uma comunicação mais efetiva com seu paciente e a vivência desse momento de forma menos ansiogênica para Laura.

De forma geral, os relatos citados até então ilustram o quanto a relação estabelecida com o paciente é importante para que a díade (paciente-aluno) vivencie o cuidado de forma positiva e humanizada, bem como para que os próprios estudantes possam se sentir seguros para pensar e executar estratégias que melhor se adequem às necessidades das crianças. Os três graduandos assumiram uma postura empática, se esforçaram para que os limites dos pacientes fossem respeitados, atendendo-os dentro de uma dinâmica especial, o que pode contribuir para a manutenção de uma relação de confiança entre as partes. Ainda, pode-se pensar no impacto positivo que 0 acolhimento e o estabelecimento de um bom relacionamento estudante-paciente tem nas vivências de todos os envolvidos no tratamento odontológico.

O acolhimento, a humanização e o investimento no bem-estar do paciente tem sido aspectos enfatizados nas políticas do Ministério da Saúde, a ponto deste elencar a humanização dos serviços de saúde como um de seus programas prioritários (Brasil, 
2002; Brasil; 2013). Voltando a atenção ao campo da Odontologia, destaca-se a importância que recai sobre o profissional da saúde e seu comprometimento em transcender a saúde bucal e acolher o usuário que sofre (Guerra et. al. 2014). Curar na Odontologia ultrapassa o campo do conhecimento científico, deste modo a atuação desses profissionais oscila nesse equilíbrio entre técnica e habilidade, formação científica e visão humanista da promoção da saúde. Assim, há o entendimento de que atualmente a humanização em Odontologia está alicerçada no tripé acolhimento e direito do usuário, prática odontológica e construção/manutenção de um modelo organizacional humanizado (Almeida, 2009; Usual et. al., 2006).

A postura empática identificada nas falas de Ana e Carlos pode ser um indicador de que a maneira como lidaram com as dificuldades e demandas específicas do atendimento Odontopediátrico estão condizentes com o que os autores citados referem como esperado de uma pessoa nessa posição. Os estudantes adequaram sua forma de atuação para atender às demandas particulares de cada paciente e facilitar a colaboração dos mesmos para conseguir executar os procedimentos. Tal postura sinaliza uma possibilidade real dos estudantes conseguirem viver o percurso na Clínica-escola de maneira mais humana e positiva, fazendo do atendimento Odontopediátrico um momento de cuidado em saúde pautado na cooperação mútua, acolhida e na corresponsabilização de todas as partes envolvidas.

Ainda, sobre a dificuldade enfrentada por Laura, percebe-se a necessidade de uma acolhida dessa demanda por parte de seus supervisores. Tranquilizar os estudantes sobre os possíveis problemas que podem ser enfrentados na Clínicaescola e orientá-los acerca de possibilidades de resolução e manejo pode ajudar a diminuir um pouco a ansiedade diante dessas novas vivências. A troca de experiências é importante nesse momento inicial para que os estudantes ampliem seu repertório de estratégias, pois muitos deles estão vivenciando seus primeiros contatos com situações desafiadoras e muitas vezes específicas do universo infantil. Também, a presença de algum supervisor junto ao estudante durante esses momentos de maiores dificuldades pode ser de ajuda para uma melhor elaboração dos sentimentos capazes de interferir negativamente no andamento do tratamento realizado.

No contexto das dificuldades encontradas no atendimento à criança, Ana relata uma experiência que a impactou: 
"A criança tinha três anos e ela tinha um medo muito grande, muito grande mesmo de dentista. Ela tem a saúde perfeita... seria indicado uma sedação consciente (sedação através do uso de algum medicamento) para ela porque ela realmente não é nenhum pouco cooperativa. (...) ela é realmente muito, muito, muito medrosa. Ela chora, se debate... ela pode botar em risco a saúde dela fazendo isso, porque a gente tá fazendo um procedimento que as vezes é invasivo. E assim, pode dar risco pra gente também! Porque a gente tá lá anestesiando, ela mexe aí a agulha vai no nosso dedo, sabe? Então é uma exposição. É complicado no caso dela. No caso dela eu realmente fiquei um pouco chocada. (...) eu infelizmente tive que lançar mão da contenção física. (...) E ela mesmo com essa contenção se mexia muito. Ela batia a cabeça na cadeira odontológica. Eu ficava com muito medo de lesar ela, e de machucar. A mãe dela nunca reclamou da gente fazer isso. Porque assim, nas primeiras vezes a gente tentou, tentou de todas as maneiras. Nas primeiras três, quatro vezes eu só fiquei conversando com ela na cadeira, tentando convencer ela que o tratamento era bom pra ela. Na profilaxia eu tentei, ainda consegui fazer um pouquinho de profilaxia na boca dela com o motorzinho do dentista. Ela deixou, mas depois ela começou a chorar, se debater, gritar e eu não conseguia mais fazer ela colaborar. (...) Nem a radiografia ela deixava fazer. Ela vomitava durante o atendimento, chorava o tempo inteiro e ficava gritando também o tempo inteiro. O tempo inteiro, não... acho que só raras vezes que ela dormiu na cadeira. Depois que ela chorava bastante ela dormia na cadeira. (...) E, assim, isso me chocou muito por que eu nunca tinha atendido uma criança que realmente me desse tanto trabalho assim. E eu fiquei com muito medo desse atendimento, sabe! Tanto é que um dia eu atendi ela primeiro... a segunda e terceira paciente que eu tive no mesmo período eu não consegui atender com tanta alegria assim, sabe? Eu tava triste, tava frustrada. E a professora percebeu isso e ela me ajudou nos outros atendimentos, ela ficou mais perto de mim. E ela falou assim: 'Olha, não precisa se preocupar porque pediatria é assim mesmo. Uma criança às vezes dá mais trabalho do que você esperava, então você tem que agendar talvez no segundo horário, ou então lançar mão de outros métodos'."

(Ana, estudante)

Ana, ao receber uma menina de três anos para atendimento que, em sua análise, tinha muito medo de dentista e manifestava tal medo durante as consultas se debatendo e chorando, explicita a dificuldade de entrar em relação com essa paciente e afirma ter ficado "chocada" [sic] com o caso. Ela relata que não foi possível o estabelecimento de um vínculo que facilitasse a colaboração da criança e isso parece ter influenciado na decisão da estudante por utilizar a contenção física.

Ainda, relata um pesar por optar pelo uso da contenção física para a realização do atendimento, prática esta utilizada na Clínica Odontopediátrica quando a criança não aceita as intervenções do profissional/estudante. Ela busca justificar sua decisão falando sobre os riscos envolvidos durante intervenções invasivas em pacientes agitados. Destaca que mesmo após a realização da contenção a menina continuou a se movimentar muito e bater a cabeça na cadeira odontológica, o que parece um comportamento que expressa o medo e desconforto da paciente com a situação vivida. O comentário de Ana acerca da movimentação da criança mesmo após a 
contenção parece uma justificativa de que a mesma precisava de fato ser realizada. Sua argumentação de que tentou diversas estratégias antes de optar pela contenção parece sinalizar um desconforto da estudante com a aplicação dessa técnica.

Ana afirma ter tentado adaptar a criança através da argumentação e intervenções profiláticas no intuito de convencê-la de que o tratamento era algo benéfico, mas não obteve sucesso em suas tentativas. Ressalta-se que a estudante, realizando o tratamento de uma criança de três anos que não colabora, tenta argumentar com a criança de que aquelas intervenções desconhecidas eram para seu benefício. Entendendo que o paciente estava desconfortável nesse momento relatado, tem-se que tal desconforto e a sensação de dor são eventos estressantes que geralmente ocorrem antes que os pacientes consigam perceber o benefício que 0 tratamento odontológico trará à sua saúde, assim é possível compreender que tal dinâmica seja responsável pelo aumento da sensação de medo que acaba sendo expressa através de comportamentos de não colaboração ou de resistência (Rolim et. al., 2004).

Essa constatação ajuda a compreender as dificuldades da paciente em corresponder positivamente às tentativas de convencimento que Ana utilizou, pois aparentemente sua abordagem pode ter contribuído para a resistência da paciente. Ao priorizar a argumentação durante as sessões de familiarização com uma criança de três anos que estava amedrontada, a estudante parece não considerar naquele momento o uso de outras possibilidades de intervenções mais adequadas à idade da criança, como por exemplo, o uso de materiais e estratégias lúdicas, vídeos, livros infantis sobre o tratamento odontológico, entre outras. Percebe-se, a partir desse relato, que se faz necessário no atendimento infantil o uso de uma abordagem lúdica e empática que facilite a criança a elaborar essa nova vivência, dentro dos limites que são esperados em cada fase do desenvolvimento. Tentar o envolvimento de uma criança dessa idade através do uso de elementos comuns a sua realidade (brinquedos, desenhos animados, histórias infantis) parece ser uma possibilidade com maiores chances de que o atendimento seja efetuado com menos sofrimento para os atores envolvidos.

O relato de Ana aponta que a estudante não conseguiu estabelecer um vínculo com sua paciente e o atendimento transcorreu de forma tumultuada. Atender uma 
criança pequena que não está confortável parece ter sido um grande desafio, visto que além de estar vivenciando uma experiência nova no cuidado em saúde em um ambiente estranho, precisa lidar com uma criança que encontra-se bastante amedrontada. Ainda, apesar de Ana ter dedicado algum tempo para tentar ajudar a criança nesse enfrentamento, as estratégias utilizadas pouco ajudaram e não surtiram o efeito esperado. A paciente continuou bastante amedrontada, a estudante não conseguiu acalmá-la nem estabelecer com ela uma relação de confiança, que possivelmente seria um facilitador para que a criança sentisse segurança diante dos procedimentos e assim conseguisse cooperar e participar ativamente do cuidado que estava sendo ofertado.

Ana relata, ainda, que ficou amedrontada no seu primeiro atendimento a uma criança que "deu muito trabalho" [sic]. No dia em que recebeu essa criança, ela não conseguiu atender seus outros pacientes da forma que esperava e também se sentiu triste e frustrada. Ainda, segundo a estudante, a professora/supervisora percebeu tal fato e tentou ajudá-la, ficando mais próxima e justificando que esse tipo de intercorrência era comum em Odontopediatria. O comentário da professora parece não acolher satisfatoriamente a demanda emocional da estudante e ainda naturaliza o episódio de sofrimento relatado pela mesma, onde sugere ser necessário que Ana se habitue ao tipo de situação relatada, não avaliando junto com ela o que poderia ser feito para que tanto Ana quanto sua paciente pudessem ter uma vivência menos traumática dentro do tratamento. Naturalizar tal situação de dificuldade pode referendar que nada há para ser feito no sentido de ajudar a criança e a estudante a lidarem melhor com essa experiência de cuidado em saúde.

Ainda, em relação ao relato da aluna sobre a supervisão recebida, é possível perceber que as questões relacionais que estavam envolvidas no atendimento não foram discutidas, tampouco a importância de adequar as estratégias de intervenção à idade da paciente. Ana parece não encontrar possibilidades e estratégias que pudessem ajudá-la na formação de um vínculo com a criança, e que fossem capazes de facilitar a adaptação da paciente em relação a ela e ao tratamento. A partir do momento em que a professora naturaliza o comportamento resistente da criança e informa que não havia nada de diferente que pudesse ter sido feito para melhorar a aceitação dela ao tratamento, é reiterada uma primazia do biológico em relação ao olhar integral. 
Ainda no contexto de dificuldade, Lucas relata uma experiência onde o uso da contenção física o fez se sentir aliviado:

(...) teve criança que não me deixou trabalhar de jeito nenhum, mesmo eu conversando, com a mãe ou sem a mãe, ficava chorando, chorando, esperneando, (eu) pedia pra abrir a boca e não abria... ia colocar algum instrumental perto da boca já fechava, ficava chorando, não me deixava trabalhar. Nesse caso aí eu precisei de gente pra me ajudar a segurar a criança, fazer contenção mesmo. Foi a única vez que aconteceu isso, Pra mim, eu trabalhei e acabou, mas pra criança não é bom, né? (...) Olha, eu tava tão irritado por que a criança tava me deixando irritado que foi um alívio, até. 'Nossa, graças a Deus, vou trabalhar logo!'”.

(Lucas, estudante)

No atendimento que o estudante descreve, a criança chorou muito, não atendeu aos seus pedidos e nem o deixou examiná-la. Segundo Lucas, foi a única vez em que ele precisou recorrer ao uso da contenção física. Apesar disso, é possível observar que há uma responsabilização da criança pelo fato do estudante não conseguir atendê-la sem a necessidade da contenção. Lucas usa a expressão "não me deixava trabalhar" [sic] para justificar o uso da estratégia, como se não houvesse outra forma de intervir que fosse capaz de ajudar a criança no enfrentamento das suas dificuldades em relação ao tratamento odontológico.

Nessa situação, o estudante inicialmente tenta acalmar a criança através da tentativa de convencê-la a colaborar e não obtém sucesso. Por ser criança, é possível que o mesmo não consiga ainda compreender através de argumentos lógicos que os procedimentos são necessários apesar do desconforto e dor que podem causar, e que não o machucarão - caso parecido com a situação vivenciada por Ana, relatada anteriormente. Lucas não refere ter utilizado outras estratégias além da conversa para tentar acalmar a criança. Considerando que ela está em um ambiente novo, com instrumentos e pessoas desconhecidas ao seu redor, é esperado que tenha se sentido ameaçada e amedrontada.

Estudos que têm investigado a origem da ansiedade e do medo envolvidos no tratamento odontológico sugerem que o paciente percebe como aversivos aspectos relacionados aos comportamentos dos profissionais e aos procedimentos que estes utilizam durante o atendimento (Possobon et. al., 2007). Milgrom, Mancl, King e Weinstein (1995) investigaram, através de questionário aplicado em 895 crianças de 05 a 11 anos, alguns estímulos evocadores de medo e ansiedade nesse tipo de 
atendimento. Os maiores escores de medo estavam relacionados a procedimentos realizados no tratamento, como "aplicação de injeção" e "uso da broca".

Costa e Moraes (1994) apontam que os pacientes relataram como aversivos aspectos relacionados à pouca interação do profissional com o paciente e, ainda, ressaltam a importância das práticas odontológicas preventivas que além de evitarem o agravamento dos problemas na saúde bucal ainda podem prevenir o medo provocado pelas intervenções invasivas. Tais afirmações parecem justificar a manutenção do comportamento de não colaboração da criança, visto que o estudante não parece utilizar de estratégias que poderiam ser mais eficazes, adequadas à idade e ao contexto que seu paciente vivenciava.

Lucas refere ainda ter se irritado com a criança. Isso pode ter influenciado sua postura diante do atendimento, uma vez que o estudante optou por realizar o procedimento com a criança contida e, apesar de pontuar que a contenção física não é boa para o paciente pediátrico, se sentiu aliviado por conseguir realizar seu trabalho. Assim, partindo dos elementos presentes em seu relato, é possível dizer que o estudante conduziu seu atendimento focado em realizar os procedimentos odontológicos planejados, dando pouca atenção às demandas pessoais do paciente, o que caracteriza a intervenção relatada como uma atividade focada na técnica e com pouco comprometimento em relação aos aspectos emocionais da criança.

Carlos, por sua vez, apesar de relatar dificuldades encontradas em seu percurso, parece tê-las contornado:

"Bom, eu gosto de lidar com criança. Eu tive dificuldades sim com crianças que eram um pouco mais problemáticas... crianças que têm um medo muito grande, por que tem toda a insegurança... eu tô começando agora, aí tô na faculdade... ainda que tenha as professoras perto, a gente teve dificuldade... a gente teve certo receio com certos procedimentos."

(Carlos, estudante)

"(as dificuldades) foi quando a gente pegou os pacientes mais problemáticos, os pacientes com mais medo, paciente que colaborava menos com a gente. Nesse momento que foi mais difícil... só que durante o curso a gente foi aprendendo a lidar melhor com esses pacientes, e quando a gente aprendeu realmente a lidar com esses pacientes foi quando eu vi que dava pra melhorar, dava pra ser melhor do que aquilo que a gente imaginava. Então... aí eu fiquei mais confiante." 
Carlos relata em sua entrevista que apesar de ter certa afinidade com crianças, teve dificuldades com aquelas que "eram um pouco mais problemáticas..." [sic]. Esse termo foi usado por ele para se referir a crianças que tinham medo do tratamento odontológico. Para ele, a sua falta de experiência prática na clínica, aliada ao medo das crianças, fez com que sentisse "certo receio com certos procedimentos" [sic].

Ao utilizar reiteradas vezes o termo "problemáticas", Carlos pode remeter à crença de que a criança que não colabora com o tratamento tem algum tipo de problema, e isso centraliza na criança a responsabilidade pelas dificuldades ocorridas no atendimento. Tal forma de pensar pode gerar uma culpabilização do paciente e "isentar" o profissional de sua corresponsabilidade frente ao tratamento. Vale ressaltar que o estudante está realizando pelas primeiras vezes os procedimentos odontológicos em crianças e, muitas vezes encontra-se inseguro e com medo, o que impacta na relação que a criança estabelece com o tratamento odontológico e com o estudante.

Carlos ainda refere por diversas vezes ter conseguido contornar as dificuldades encontradas nessa trajetória. Esse esforço do estudante corrobora com Monteiro et. al. (2012), quando afirma que é tarefa do Odontopediatra deixar a criança em condições de receber futuros atendimentos odontológicos, ou seja, é responsabilidade do cirurgião dentista se esforçar para propiciar aos pacientes uma experiência positiva, com tranquilidade frente ao tratamento e acolhida de seus medos e anseios.

Sabe-se que o desenvolvimento de relações interpessoais é fundamental para que seja estabelecido um melhor entendimento entre usuário e profissional/estudante. Para tanto, faz-se necessário integrar a concepção de pessoa, como um ser dotado de subjetividade, se afastando de perspectivas reducionistas que focam o corpo e a sua sintomatologia (Guerra et. al, 2014). Os pacientes desejam profissionais capazes tecnicamente e humanamente no que se refere às relações sociais, desse modo, é necessário que seja possível uma visão de homem que valorize a complexidade do humano, pois assim o tratamento poderá responder melhor as necessidades da díade, sendo mais positivo para as partes envolvidas (Canalli et. al., 2012; Guerra et. al., 2014). 


\subsubsection{Complexidade nas relações com os acompanhantes}

Como vem sendo discutido, o atendimento à criança possui algumas especificidades capazes de influenciar na oferta do cuidado. Ao atender um paciente pediátrico, o profissional precisa se comunicar com o responsável para obter informações e o consentimento para a realização dos procedimentos. Além disso, o acompanhante também se configura enquanto corresponsável no cuidado à saúde da criança, contribuindo para que ocorra uma atenção integral. Nesse sentido, o relacionamento entre pais/acompanhantes e o Odontopediatra é uma importante questão no contexto estudado, considerando que essa relação pode influenciar em diversos aspectos o atendimento ofertado à criança.

Nesse momento, serão abordadas questões referentes ao relacionamento entre estudantes e acompanhantes na Clínica-escola e às dificuldades vivenciadas a partir da ótica dos graduandos.

Jorge relata uma situação de atendimento onde a proximidade e a interferência da mãe de seu paciente o fizeram se sentir apreensivo:

"Teve uma mãe de uma paciente que questionou por que a gente tava fazendo uma exodontia. Tirar um dente de leite da criança. Então a gente conversou com ela dizendo que como aquele dente tava com pouca implantação, ele tava muito molinho na boca, se a criança aspirasse ia ser um risco, ela podia ir pro hospital e ter maiores complicações. Era um procedimento que não precisava de anestesia local, a gente podia fazer com anestesia tópica (pomada anestésica) mesmo. Então a criança era muito apreensiva. Nós conseguimos contornar em partes, por que não foi possível contornar tudo. Mas a mãe, ela acabou tendo uma atitude até mal educada com a gente. Ela não queria que aquele procedimento fosse realizado. (...) ela falou assim 'Ah, vocês podiam passar mais anestésico'. Aí nós passamos mais anestésico, aí ela achou que aquele não era suficiente e a nossa resposta foi 'Olha mãe, a gente sabe, a gente é treinado pra fazer esse procedimento. A sua filha não tá sentindo dor, ela tá com medo do procedimento' e a mãe disse assim 'Ah, mas não é em vocês, né?!' Então ela tava bem... mas não com palavras educadas, ela foi bem, é... reservada nesse sentido. No final deu tudo certo, mas foi uma apreensão que a gente teve.".

(Jorge, estudante)

É possível perceber no relato que o estudante parece incomodado com a "interferência" da mãe. É compreensível que nesse contexto, diante de uma experiência nova e ansiogênica para ele, Jorge interprete as colocações da acompanhante como questionamento ou desqualificação de sua prática profissional. Assim, numa possível tentativa de demonstrar à mãe que tinha o controle da situação, o estudante parece não legitimar o papel dela dentro do atendimento. 
No atendimento odontopediátrico, a relação que se estabelece é com a criança e seu acompanhante, então se faz necessário considerar a percepção desse acerca da criança. Ouvi-lo colabora com o desenvolvimento de uma relação de confiança entre a tríade. $O$ acompanhante, geralmente a mãe, é alguém que conhece as particularidades da criança e pode ser um aliado do profissional no sentido de auxiliar na adaptação, na execução do tratamento e, ainda, na construção de uma relação amigável entre estudante/Odontopediatra e paciente. Para isso, são necessárias mudanças que abarquem as pessoas e tecnologias envolvidas nesse cuidado.

Tais mudanças esperadas no contexto da Odontopediatria também estão relacionadas com a valorização de ações que estejam voltadas ao cuidado, podendo assim ampliar a visão tanto das situações quanto das pessoas envolvidas. Nesse sentido, é preciso que a equipe de saúde compreenda a necessidade de que todos os membros da coletividade, inclusive os acompanhantes, possam se sentir beneficiados e beneficiários nesse processo. Assim, busca-se ações de atendimento humanizado, ou seja, a manutenção de um ambiente de cuidado humano que envolva a gestão, os trabalhadores e os usuários, de modo que todos cuidem e sejam cuidados (Pereira et.al., 2010).

Pode-se hipotetizar que no atendimento relatado, a mãe poderia estar ocupando um lugar de corresponsável no cuidado, contribuindo para o bom andamento do serviço prestado. Mas, na situação exposta por Jorge, percebe-se pela reação da mãe que ela não estava confortável com a forma como o atendimento da criança estava sendo conduzido. O estudante não investigou com a mãe qual a dificuldade que ela estava percebendo em relação ao procedimento realizado, deu andamento ao atendimento e é no momento em que argumenta acerca das observações dela que ocorre a situação de atrito entre eles. Acolher e validar 0 sentimento e as contribuições dessa mãe poderia ser de ajuda para o estabelecimento de um vínculo com ela e assim realizar o atendimento com menos sofrimento para os envolvidos.

Ainda, vale ressaltar que o estudante, em sua inexperiência profissional, pode ter se sentido questionado pela mãe sobre suas habilidades e capacidade de realizar o tratamento da maneira que era esperada. Ao ser confrontado, ele parece tentar se afirmar como alguém que está controlando a situação e desconsidera o fato de que 
ela, enquanto cuidadora conhece seu filho e pode estar identificando uma dificuldade dele em relação ao procedimento. Nesse sentido, mesmo avaliando que a criança poderia não estar sentindo dor, ouvir a mãe e acolhê-la naquele momento poderia ser o início da construção de um vínculo com ela, baseado numa relação de horizontalidade, que por sua vez ao se sentir parte dessa tríade poderia cooperar para o bom andamento do tratamento.

Laura relata alguns aspectos de sua relação com os acompanhantes de seus pacientes, apontando o fato de que tinha um relacionamento melhor com as crianças de que com seus pais:

“(...) Sempre, tive um relacionamento bom com as crianças. O problema mais era os pais, que eu acho que eu batia de frente, assim, as vezes, por que chegava umas criança com a boca arregaçada, sabe?! Quase não tinha dente na boca! Eu falava, eu chamava o pai por que eu culpo os pais, eu chamava os pais e falava: "Olha aqui mãe, cê tá vendo isso aqui?!", sabe?! Eu ficava brava com eles, eles não gostavam. Alguns abaixavam a cabeça e falavam "Não, eu vou melhorar.", e outros só aceitavam. E eu acho que isso não foi o melhor jeito de lidar, eu sei disso. Mas eu ficava chateada, sabe, com o pai. E eu demonstrava isso, pra que eles vissem o quanto eles tavam prejudicando a criança. Eu ficava chateada mesmo, então o problema mais era com eles".

(Laura, estudante)

Laura avaliou positivamente o relacionamento que mantinha com as crianças atendidas na Clínica-escola. Já com os acompanhantes, a estudante refere ter vivenciado algumas dificuldades. Ao descrever sua abordagem, ela afirma ter lidado com os pais de forma incisiva, onde "batia de frente" [sic] ao chamar a atenção para os cuidados em relação à saúde bucal da criança. Partindo do relato da estudante, pode-se pensar que ela imprimiu em sua relação com os acompanhantes uma concepção de cuidado baseada na culpabilização dos pais pelos problemas de saúde de seus filhos, não considerando o contexto no qual essas famílias vivem. A aluna não busca identificar e entender as causas implicadas nos problemas de saúde apresentados pelas crianças que podem, por exemplo, estar inseridas em um contexto de vulnerabilidade.

O conceito de vulnerabilidade também norteia as políticas de humanização do cuidado, e a partir do que foi proposto por Ayres et. al. (2003), abrange uma análise dos variados graus em que as pessoas estão sujeitas ao adoecimento, avaliando a disponibilidade de recursos que têm acesso para se preservar de eventuais ameaças à saúde. A vulnerabilidade compreende três dimensões que se relacionam 
mutuamente na constituição das ocorrências em saúde e que devem ser consideradas, a saber: vulnerabilidade individual, referente aos acontecimentos nocivos à saúde dos indivíduos, suas diferentes condições psicossociais e suas vivências; vulnerabilidade social, que analisa o ambiente sociocultural no qual a pessoa está inserida e de proteção aos direitos humanos e vulnerabilidade programática, que analisa os serviços e políticas dos diversos setores como intervenientes no processo de vulnerabilidade (Ayres et. al., 2003; Ayres, Paiva, Buchalla, 2012; Ayres, Paiva, França Júnior, 2012).

As crianças e adolescentes atendidos em Clínica-escolas possuem, em sua maioria, uma condição socioeconômica menos favorecida, o que torna essencial que a avaliação dos fatores envolvidos no adoecimento considere as dimensões de vulnerabilidade, sob as quais o paciente pode estar inserido. A culpabilização de pais e cuidadores e a compreensão de que o adoecimento seja apenas consequência da negligência do cuidado cotidiano nas famílias, não amplia as estratégias de promoção da saúde e é de pouca ajuda no contexto da assistência. Ressaltando que as famílias, muitas vezes, ao receberem orientações adequadas às suas condições de vida, são estimuladas a se corresponsabilizar pelo cuidado da saúde dos filhos e podem se tornar importantes aliados na promoção da saúde.

Em termos das políticas públicas, entre os deveres do Estado está o de informar e educar a população, a partir da atenção primária, para que os vínculos entre equipes e comunidades contribuam para o desenvolvimento da autonomia e corresponsabilização dos usuários, potencializando as ações em saúde e diminuindo os índices de vulnerabilidade. Desde os anos 80 as ações em saúde voltadas à infância foram iniciadas enquanto política especial no Brasil e asseguradas através da nossa legislação e das políticas de saúde (Piani et. al., 2014). Através do Estatuto da Criança e do Adolescente - ECA foi iniciada uma renovação dos direitos fundamentais na sociedade brasileira em relação à proteção social e à política pública diferenciada ao público infanto-juvenil, contemplando o direito à vida e à saúde através do SUS e garantindo um acesso universal e igualitário às ações e serviços para promoção da saúde.

Assim, podemos repensar também a formação dos estudantes da área da saúde para que eles estejam aptos a lidar com tais demandas, onde seria necessário 
um planejamento de intervenções baseado na corresponsabilização do cuidado a partir do entendimento do contexto que culminou nos agravos em saúde, ampliando as possibilidades de compreensão e diminuindo posturas simplistas e reducionistas em relação aos mesmos. Dessa forma, educar e orientar fazem parte das ações de cuidado integral que é esperado desses profissionais.

Laura relata outro atendimento onde emergiram aspectos socioeconômicos da vida da criança e sua família:

"Tinha uma mãe que ela era muito esforçada. O filho dela estudava em escola particular, pra você ter uma noção. Só que ela teve que tirar ele e ele era muito inteligente. Nossa, que menino inteligente sabe?! De esperto, assim, já sabia tudo que tava acontecendo, não fazia birra, nada. Cuidava dos dentes, a boca dele era maravilhosa. Só que ela teve que tirar ele da escola particular por que ela tinha perdido o emprego e só o marido que tava colocando renda em casa. Então eu falava assim pra mãe dele 'Oh, se não consegue colocar ele numa particular contrata uma pessoa pra dar aula, sabe?! Se ele tiver tendo alguma dificuldade contrata uma pessoa pra aquela matéria específica que com certeza é mais barato'. Tem um professor... nessa idade (da criança) esses professores conseguem ajudar com tudo, né?! Não só uma matéria. Então eu tentava ajudar, assim... tinha mães que eu me aproximava muito, a esse ponto de dar conselhos, sabe nessa área. Então era boa minha relação com os pais".

(Laura, estudante)

A estudante inicia seu relato caracterizando seu paciente como uma criança bastante inteligente e a mãe dele como uma pessoa esforçada, principalmente por ela conseguir manter a criança numa escola particular. Cabe ressaltar que a clientela da Clínica-escola estudada é composta por famílias de baixa renda. Além desse aspecto, o menino também tinha a saúde bucal preservada. Em dado momento, a mãe da criança perdeu o emprego e precisou retirá-lo da escola particular e Laura, na tentativa de ajudar a pensar possibilidades, decide aconselhar a mãe acerca do que ela poderia fazer frente às escolhas da família.

Conversar com a mãe sobre o contexto geral da sua nova realidade, as outras áreas da vida da família que serão impactadas por essa mudança, ampliando o olhar acerca da situação, poderia ajudá-la a ressignificar tal vivência e pensar em maneiras mais adequadas ao novo padrão de vida. Com relação ao bem-estar da criança, outra possibilidade poderia ser a estudante buscar compreender melhor essa nova realidade, conversando com a mãe sobre a adaptação da criança na escola pública.

Essa situação vivida por Laura é representativa do quão amplas são as demandas existentes dentro dos serviços de saúde. Isso requer dos estudantes/profissionais um preparo que transcende a excelência técnica, que 
envolve uma sensibilidade para questões que vão além da saúde física. Olhar para o usuário a partir de uma perspectiva que integralize as dimensões de vulnerabilidade, Ihe confere a possibilidade de oferecer um cuidado humano e acolhedor. Para tanto, faz-se necessário que a formação dos cirurgiões-dentistas seja capaz de abranger e considerar a importância de trabalhar essas competências e de propiciar condições para que os próprios estudantes se apropriem de concepções ampliadas de cuidado, para se tornarem profissionais comprometidos com a humanização dos serviços.

\subsubsection{Desafios na articulação entre formação teórica e a prática do atendimento à criança}

Nesse sub eixo foram reunidos os conteúdos que apontam a percepção dos participantes e alguns relatos de suas experiências que remeteram ao processo de ensino/aprendizagem vivenciado na faculdade, refletidos na forma como lidaram com as especificidades do atendimento à criança na Clínica-escola e na aplicação de conceitos e técnicas aprendidos em sala de aula. Além disso, os participantes puderam constatar o atravessamento dos vários desafios à articulação teoria-prática dados pelo caráter humano do trabalho e pela complexidade das relações estabelecidas no contexto da clínica-escola.

Lucas relata a sua compreensão de como se deu o processo de aplicação de seu aprendizado teórico na clínica:

"Então, eu percebi assim, que na verdade teoria a gente vê muita coisa que não é levada em prática aqui nessa clínica. Tipo, 'Ah, essa criança é muito nervosa, vamos deixar uma clínica só pra conversar com a criança, aí uma segunda clínica só pra mostrar os equipamentos, fazer uma profilaxia talvez...'. Mas na prática não é o que acontece aqui, por que chega o paciente a gente tem que atender, por que a gente tem meta, então não pode ficar, entre aspas, perdendo clínica só conversando com o paciente. A gente chega aqui, paciente tá nervoso, a gente tenta acalmar do jeito que pode. Se ele não acalmar a gente tem que fazer o procedimento mesmo assim. Se ele não deixar fazer o tratamento a gente dispensa, aí já chama o próximo. Eu entendo que tem muito o que fazer aqui, né?! A gente aprende o jeito certo, mas aqui a gente acaba mudando um pouquinho".

(Lucas, estudante)

O estudante relata um distanciamento entre as orientações que os alunos recebem nas aulas teóricas e o que é possível realizar na prática na clinica escola, tendo em vista as regras estipuladas na mesma. Ele afirma que mesmo sabendo que 
o esperado fosse observar e acolher as necessidades da criança havia também a necessidade de atender a uma exigência pelo cumprimento de metas, definidas pelo número de procedimentos a serem realizados para sua avaliação acadêmica.

Nesse contexto, observa-se que Lucas faz referência direta de sua percepção sobre uma cisão entre teoria e prática, onde mesmo sendo orientado acerca da necessidade de se realizar uma ambientação/familiarização das crianças antes do início dos atendimentos, o estudante aparentemente não dispõe de um sistema de avaliação e funcionamento na Clínica-escola que facilite uma maior adesão a essas práticas. Tal cisão entre o que é ensinado e o que é praticado parece estar relacionada a uma lógica formativa perpassada pela racionalidade biomédica, que é compreendida como o paradigma hegemônico na medicina ocidental. Esse paradigma parte da epistemologia centrada na doença e atravessa a prática e o saber médico, o trabalho e a formação dos profissionais da saúde (Mattos, 2008).

Assim, observa-se uma destituição da subjetividade presente no adoecimento, o que, de acordo com Goulart e Chiari (2010), promove a negação do sujeito, reduzindo sua relação com o profissional aos aspectos que dizem respeito a seu adoecimento. Tal redução da pessoa à sua doença é vista dentro do processo de formação dos profissionais a partir de uma ênfase na objetividade e competência técnica e desvalorização das manifestações subjetivas existentes na relação entre profissional/estudante e paciente, o que nega as experiências de sofrimento vivenciadas tanto pelos pacientes quanto pelos profissionais da área da saúde.

Por outro lado, busca-se avançar em direção a um modelo biopsicossocial de atenção em saúde e, nesse sentido, diversas intervenções têm sido efetuadas no campo da Odontologia. O ensino na área passou a ser fundamentado pela Lei de Diretrizes e Bases da Educação Nacional (LDB), instituída através da Lei № 9394 de 20 de dezembro de 1996, que regulamenta as bases conceituais, filosóficas, políticas e metodológicas que devem permear os projetos pedagógicos. O ensino se fundamenta nas Diretrizes Curriculares Nacionais (DCN) dos cursos de graduação em Odontologia - Resolução CNE/CES 3 de 19 de fevereiro de 2002 que propõe, em consonância com a LDB, que os cursos de graduação em Odontologia estejam comprometidos com a formação de profissional generalista, crítico-reflexivo, com 
formação técnico-científica e ético-humanista para atuar em todos os níveis da atenção (Brasil, 2002).

Essas medidas foram fundamentais para a renovação das grades curriculares dos cursos de graduação, que precisaram se adequar ao novo paradigma proposto para a formação em Odontologia. Mas, apesar dos avanços feitos nessa busca pela promoção de uma Odontologia mais acolhedora e comprometida com a natureza biopsicossocial de sua clientela, pode-se pensar, através do relato de Lucas, que os estudantes ainda estejam vivenciando um processo de formação profissional que reproduz na sua lógica de ensino estratégias e enfoques técnicos que parecem estar alinhados com o modelo biomédico. Segundo Lazzarin, Nakama, Cordoni Júnior (2007), a formação oferecida nos cursos de graduação em Odontologia é excessivamente técnica em detrimento de uma formação humanística. Ainda, ressaltam a necessidade de transformação do processo de ensino-aprendizagem dos Cirurgiões-dentistas, o que consideram como sendo algo complexo e dinâmico que envolve mudanças que vão desde as concepções em saúde até as práticas. Inclui ainda uma modificação nas relações construídas entre pacientes e Cirurgiões Dentistas, Cirurgiões Dentistas e equipe, bem como docentes e discentes.

Através do relato de Lucas é possível entender que, apesar de haver uma tentativa de conscientizar os estudantes por meio de orientações sobre a importância de se respeitar o tempo de adaptação da criança, na prática a dinâmica dos atendimentos ainda acontece com enfoque tecnicista e pouco comprometimento com a compreensão das especificidades da criança. Quando o estudante, ao falar sobre o nervosismo do paciente, afirma que "se ele não acalmar a gente tem que fazer o procedimento mesmo assim. Se ele não deixar fazer o tratamento a gente dispensa e chama o próximo" [sic] ele objetifica o paciente, parecendo reconhecê-lo apenas como o problema de saúde que o traz à clínica e precisa ser sanado. Neste caso, Lucas parece priorizar o cumprimento das metas acadêmicas em detrimento da necessidade de estabelecer com essa criança uma relação que facilite a ela o enfrentamento desse momento de dificuldade. Ainda, ao objetificá-la, o estudante acaba por distanciar sua prática do modelo de atenção integral que é esperado no cuidado em saúde.

Essa objetificação do paciente é definida como uma prática que se dá através de uma abordagem centrada na dimensão biológica do indivíduo. Ao olhar para o ser 
humano partindo da fragmentação que separa seu corpo de sua história, suas vivências e suas particularidades psicossociais, o paciente é reduzido à condição de objeto e transformado em "coisa manipulável" sobre a qual o profissional da saúde intervém com medidas prioritariamente prescritivas e curativas. (Barros \& Gondim, 2014; Camargo Jr., 1992; Fertonani et al., 2015; Guedes et al., 2006). Nesse processo, a dimensão subjetiva desaparece e o paciente, agora é tratado como "coisa", visto que a relação dialética subjetiva-objetiva realizadora do sujeito é cindida. Percebe-se, assim, a presença predominante do paradigma biomédico dentro da situação relatada pelo estudante.

A valorização do tratamento centrado na perspectiva biológica/tecnicista também foi retratada por Lucas em sua experiência de atendimento na Clínica, onde seu foco pareceu estar na realização de procedimentos, enquanto síntese de sua capacitação, se sobrepondo à preocupação com as relações que operam no atendimento odontológico:

"Não tem a obrigatoriedade de fazer todos os procedimentos, mas eu, por exemplo, quis fazer tudo que eu podia fazer pra poder sair daqui capacitado. Então eu poderia fazer menos coisas. Eu ganhei bastante ponto, por que a gente fazia um procedimento e ganhava um ponto. E tinha uma meta que a gente tinha que chegar numa determinada pontuação. Tinha época que eu tava com uma pontuação boa. Eu podia ficar sem fazer nada, mas eu preferia fazer as coisas, né. Preferi pegar paciente um pouco mais complicado pra eu aprender. Então... é, pra mim foi a preocupação de fazer tudo que eu podia. Mas eu acho que se alguém quisesse pegar e ficar só falando com o paciente poderia. Eu que não quis".

(Lucas, estudante)

"Foi um processo pra eu aprender o jeito de tratar as crianças, por que no começo eu ficava com muito receio, a criança ficava falando que tava com dor e eu 'Ai, e agora? Será que eu vou mexer aqui mesmo?', mas depois eu percebi que a maioria era só manha, né?!".

(Lucas, estudante)

No relato de Lucas é possível perceber que há uma priorização da formação técnica em detrimento da integralidade do cuidado que abarca a subjetividade presente na atenção à saúde $O$ estudante afirma que seu foco estava em realizar o maior número possível de procedimentos técnicos para que pudesse sair da Faculdade como um profissional qualificado. Partindo disso, é possível inferir que para ele o conceito que permeia uma atuação de qualidade envolve quase que exclusivamente os aspectos técnicos da profissão, que sem dúvidas são de fundamental importância para o desempenho de suas funções, afinal ao procurar um 
profissional da saúde bucal o paciente anseia por um atendimento resolutivo de suas necessidades. Mas, a partir da fragmentação de si e do outro, ou seja, reduzindo o tratamento ao biológico, a competência profissional à técnica, desvitaliza o atendimento e pode gerar muito sofrimento (Camargo Jr, 1992).

A opção de Lucas em realizar o máximo de procedimentos técnicos possível demonstra sua preocupação no sentido de estar bem preparado para as demandas do consultório, o que pode inclusive ser o reflexo de um sistema educacional que avalia quantitativamente os alunos em relação a cada procedimento técnico realizado. Seria necessário refletir acerca da forma como os estudantes estão sendo treinados para a vida profissional, pensando que a inclusão da subjetividade no cuidado em saúde resgata a condição de ser pessoa humana.

Ainda, para o estudante, a forma como aprendeu a lidar com pacientes pediátricos foi um processo, ou seja, inicialmente vivenciou a apreensão diante da comunicação da criança sobre a dor, o que o fez hesitar na execução dos procedimentos. Para enfrentar tais dificuldades pessoais, o estudante banaliza 0 sofrimento da criança, o traduzindo como "manha" e desconsiderando as especificidades e singularidades de expressão da ansiedade. Dentro dessa lógica, ele passa a objetivar a criança para conseguir lidar com o sofrimento, tanto seu quanto dela, que emerge na situação de atenção e isso produz um distanciamento de si e da criança.

Desconsiderar as fantasias, o medo do desconhecido (professores, estudantes, procedimentos, situação), a pouca capacidade de enfrentamento, tendo em vista a idade e a fase do desenvolvimento na qual a criança se encontra, generaliza e define como "manha" uma gama de possibilidades de tradução do sofrimento e assim dificulta que o encontro humano possa ocorrer, o que de acordo com Safra (2004) provoca uma fratura no humano e reproduz o modelo biomédico.

Ressalta-se que a formação em Odontologia sofreu forte influência do modelo biomédico, com ênfase na doença, na cura e na técnica. O relato de Lucas faz referência a uma forma de atuação pautada no Modelo Biomédico de atenção. Esse modelo, segundo Koifman (2001) e Barros (2002), foi inspirado numa visão mecanicista que entende o corpo humano como algo complexo e composto de partes inter-relacionadas. Valoriza os aspectos biológicos envolvidos no adoecimento e 
pouco se detém aos aspectos psicossociais envolvidos no processo saúde-doença. Ainda, Canguilhem (1990) chama a atenção para o fato de que o modelo biomédico trabalha numa perspectiva que sugere a fragmentação do indivíduo em corpo e mente, o que favorece certo distanciamento entre profissionais e pacientes. Vale ressaltar que o processo de desenvolvimento do ensino e da prática odontológica passou por diversas fases em que recebeu influências dos modelos flexneriano e giesiano, que trazem em seus elementos fundantes o biologicismo, o mecanicismo, a tecnificação do ato odontológico, a ênfase numa Odontologia curativa, dentre outros aspectos (Moyses et al., 2003).

Júlia aborda em seu relato aspectos que são de ajuda para uma reflexão acerca do processo de ensino/aprendizagem vivenciado por ela:

Júlia: "Eu acredito que faltam maiores detalhes e explicações antes de chegar na clínica de odontopediatria. Eu acho que a gente deveria ser preparada psicologicamente e no manejo, sabe? Por que a gente vem cursando as outras disciplinas com adultos e aí a gente chega na odontopediatria e toma aquele susto. Foi um choque pra mim, particularmente (risos)".

Loredanna: "O que foi um choque para você?"

Júlia: "O comportamento das crianças, eu nunca tive contato com criança, nem na minha família.

Loredanna: "E como você se sentiu diante dessa situação?"

Júlia: "Despreparada! Falta um pouco de vivência. Eu não tinha nada de vivência com criança".

(Júlia, estudante)

"Em todas as disciplinas eu sempre entro achando que vai dar certo, achando que eu vou gostar! Eu tento me enganar, sabe?! Mas acaba dando certo. Na pediatria eu entrei com esse pensamento também, só que aí nas primeiras clínicas eu fiquei chateada, por que eu não conseguia conduzir direito. Os professores também me ajudavam mais em relação ao procedimento em si, não tanto ao manejo de tipo, sentar, fazer uma gracinha, conversar, de falar que vai dar tudo certo... esse papel era essencialmente nosso. Eu não tive tanta ajuda nesse aspecto".

(Júlia, estudante)

Para Júlia lidar com crianças na clínica foi um desafio que também demandou um empenho diferenciado no sentido de entender e vivenciar sua relação com um paciente pediátrico. Sobre a preparação para esse momento, ela afirma que os professores auxiliam os alunos prioritariamente em relação aos procedimentos técnicos e que a preparação acerca dos aspectos voltados ao relacionamento com as crianças seria responsabilidade essencialmente dos estudantes. A graduanda ainda 
refere sua dificuldade em estabelecer um relacionamento com seus pacientes, visto que estava diante de uma experiência nova e desafiadora onde não sabia como agir.

A estudante parece não ter se sentido acolhida pelos supervisores para lidar com as demandas relacionais existentes nesse primeiro contato, relatando que a ajuda recebida não estava voltada a esses aspectos. Júlia, além de estar conhecendo as especificidades que o atendimento à criança demanda, ainda se percebe enquanto alguém que não possui experiência sobre como interagir ou o que conversar com seus pacientes. Desse modo, percebe-se a necessidade de que o processo de ensinoaprendizagem integre a dimensão técnica com a humana e consiga elaborar estratégias que auxiliem os alunos tanto a oferecer um atendimento adequado às crianças quanto a lidar com suas próprias inseguranças e dificuldades manifestas nesse momento.

Percebe-se ainda a necessidade de que alunos sejam direcionados em sua formação para o desenvolvimento dessas capacidades de enfrentamento que podem auxiliar para que o atendimento odontopediátrico seja uma experiência menos ansiogênica para pacientes e estudantes. Para tanto, pode-se pensar acerca da importância de uma supervisão "aqui-agora", que auxilie os estudantes durante esses primeiros contatos com a criança, e que valorize a formação da pessoa integral e não somente em relação a aquisição de habilidades técnicas.

Para Júlia, ainda, faltou uma melhor preparação dos estudantes em relação aos aspectos psicológicos e ao "manejo" [sic] das crianças antes do início dos atendimentos no contexto da Odontopediatria. Essa falta de preparação relatada pela estudante está relacionada ao processo de ensino-aprendizagem, ao qual os estudantes foram submetidos, e que parece não ter sido de tanta ajuda no sentido de Ihes oferecer estratégias para lidar com as dificuldades presentes no estabelecimento de relações com os pacientes.

Pensando sobre as Diretrizes Curriculares Nacionais (DCN) que regem os cursos da área da saúde, tem-se o destaque à necessidade de trabalhar com os estudantes não só os conteúdos cognitivos, mas também estimulá-los a desenvolverem suas habilidades emocionais, sociais e motoras. Assim, destaca-se a necessidade de que os professores usem estratégias educacionais ativas, que sejam centradas no aluno enquanto sujeito da aprendizagem e na diversificação dos 
ambientes facilitadores da aprendizagem, visando uma articulação entre ensino, pesquisa, extensão e assistência, bem como entre teoria e prática (Costa \& Borges, 2015; Hora \& Souza, 2015; Moreira \& Dias, 2015; Silva \& Santana, 2015).

Diante do relato da estudante, de que suas necessidades emocionais e de seus pacientes não foram acolhidas pelos professores, pode-se problematizar a eficácia do processo de ensino-aprendizagem em relação a auxiliá-la para que se sentisse segura e em condições de realizar seus primeiros atendimentos odontopediátricos.

Faltaram, segundo Júlia, orientações e uma melhor preparação prévia para que ela tivesse um repertório que corresponda à nova vivência, onde tantas nuances estão envolvidas. Pensar sobre um ensino focado nos estudantes e suas dificuldades de diferentes ordens (sociais, emocionais, entre outras) dentro do atendimento, é pensar na necessidade de que esses futuros profissionais saiam da academia com preparo para lidar com as demandas que serão enfrentadas no consultório.

A estudante utiliza o termo "chocada" [sic] para expressa como se sentiu diante das dificuldades que vivenciou no atendimento à criança. Ao pesquisar o significado da palavra no Dicionário Online de Português (2009), obteve-se: "que está espantado ou escandalizado; que se encontra emocionalmente, psicologicamente ou moralmente abalado". Essa palavra parece traduzir o sofrimento experimentado por Júlia durante o atendimento, de modo que fica ainda mais evidente as dificuldades e o sofrimento que permearam as vivências da díade.

Sobre as habilidades de desenvolver um bom relacionamento com os pacientes, Júlia relata um momento que considerou de dificuldade e precisou lidar com as questões relacionais envolvidas no atendimento:

“(...) eu tive o primeiro paciente, chama João. A primeira coisa que eu tive que fazer nele foi endo (endodontia). E endo é realmente um pepino! Ele vinha todo elétrico, aí eu peguei a anamnese dele e tinha lá o comportamento. Tinha tipo ruim, sabe?! De péssimo ele já tava no ruim. E aí eu pensei 'nossa, vai ser horrível!' $E$ aí eu fiz a anamnese com ele e ele pegou no meu rosto e eu me senti totalmente dominada ali. Aí no segundo dia eu cheguei com o pulso firme, sabe?! (...) Gente, como que um menino de quatro anos consegue ter a liberdade de pegar... ele fez, tipo (reproduziu o gesto da criança, apertando as duas bochechas com uma mão, de modo que os lábios saltaram para frente). (...) Foi meu primeiro contato com ele e com qualquer outra criança. (...) Eu me senti desestabilizada. Realmente não era eu que tava mandando ali. Ah, não sei, mas todos os pacientes meus foram cilada! (risos)". 
Júlia afirma que no seu primeiro atendimento precisou realizar um procedimento invasivo. Refere, ainda, que o menino chegava "todo elétrico" [sic] na Clínica e que ao verificar sua ficha de anamnese constava uma classificação de comportamento na Clínica como "ruim" [sic]. Nesse momento a estudante afirma ter pensado que seria horrível a experiência de atendê-lo e relata que não tinha experiência prévia com crianças. A sequência de atendimento relatada por Julia, aponta para o sofrimento que vivenciou no contato com o paciente, ao interpretar a ação do menino de apertar suas bochechas como uma conduta dominadora e, a partir desse momento, optou por chegar para atendê-lo "com pulso firme" [sic].

Provavelmente, a mobilização emocional de Júlia contribuiu para que ela adotasse uma posição menos flexível em relação à criança e a fez interpretar suas atitudes como uma afronta à sua autoridade e como uma expressão do "comportamento ruim na Clínica", conforme descrito no prontuário. Parece que não havia uma abertura por parte da estudante para entrar em contato com a criança e pode conhecê-la a partir de uma relação estabelecida entre eles. Prevaleceu a ideia pré-concebida de que o atendimento seria "horrível", o que pode inclusive ter influenciado os acontecimentos posteriores e a forma como a relação foi construída, marcada por um distanciamento e autoritarismo.

Carlos ao abordar seus sentimentos em relação às dificuldades enfrentadas, relatou:

“(...) ao começar eu me sentia frustrado por que eu esperava uma coisa e começou a se mostrar outra. Eu esperava que fosse fácil pra mim, por eu gostar de criança, por me dar bem com criança, por eu já ter uma facilidade nas outras clínicas eu achei que seria fácil. E aí eu vi que por serem outros procedimentos pra se fazer, por ter que ter um cuidado maior, um apreço maior pelo paciente... uma delicadeza maior pra lidar com o paciente, um jogo de cintura... eu vi que era bem mais difícil do que eu imaginava, e isso me deixou muito frustrado no começo, por que eu achava que eu não ia conseguir ter esse jogo de cintura pra lidar com isso. E depois, não! Depois eu vi que dava pra aprender, que conforme foi passando eu fui aprendendo a lidar, eu fui aprendendo, fui desenvolvendo essas habilidades de comunicação, de controle das crianças... e hoje me vem uma sensação de mais confiança mesmo no meu trabalho, de segurança. Acho que eu precisava passar por essa frustração pra hoje eu estar seguro do que eu vou fazer".

(Carlos, estudante)

Carlos faz um percurso de descobertas dentro dessa nova experiência, podendo integrar e rever a ideia prévia ao que encontra na situação vivida no 
atendimento Odontopediátrico. O estudante teve momentos de frustração ao perceber que esse tipo de atendimento não era tão simples como ele imaginava, e pôde readequar a prática e o olhar voltado aos pacientes baseado em um processo de trabalho que já não pôde ser puramente assistencial, pois exige do profissional/estudante a modificação do ato de relacionar-se com o usuário. Desse modo, a escuta ativa do que o paciente tem a falar, buscando um esforço para compreender também o que não pode ser verbalizado, passa a ser fundamental para o desfecho positivo do tratamento (Canalli et. al., 2012).

É possível, ainda, identificar que Carlos, em seu percurso na Odontopediatria, ressignificou sua experiência que inicialmente the pareceu fácil de lidar. Através das vivências com seus pacientes, o estudante foi adquirindo um repertório mais vasto de estratégias que Ihe conferiu uma maior confiança para atuar na Clínica-escola. Acerca disso, pode-se pensar na importância da experiência prática enquanto um meio de amadurecimento profissional, onde os estudantes podem aprender, através da vivência e com o auxílio de seus supervisores, diferentes maneiras de intervir e se relacionar com seus pacientes.

Ana relata um momento de dificuldade no estabelecimento de uma boa relação com a paciente:

"Foi muito difícil! Foi muito difícil mesmo... já me peguei chorando por causa dela no banheiro, depois do atendimento odontológico porque eu me senti frustrada, eu não conseguia atender. E assim, até então, todas as crianças que eu atendi, que eu tive certa facilidade de entender, de ser lúdica com a criança, de falar pra criança o quanto que isso era importante de uma maneira que ela fosse entender e ganhar a confiança dessa criança... ah, essa mocinha, essa menininha não consegui, sabe?! Foi muito frustrante mesmo... mas assim, tô bem! Eu tô bem... eu achei que foi um desafio que eu não consegui vencer, mas valeu de experiência!"

(Ana, estudante)

Baseada em sua vivência muito singular, ela ressalta que até então havia conseguido atender seus pacientes com certa facilidade para estabelecer um relacionamento positivo com as crianças, inclusive explicando a importância do tratamento de modo que facilitasse à criança entender e, assim, confiar nela enquanto profissional. Mas para Ana foi frustrante não ter conseguido lidar com uma paciente utilizando as estratégias que a ajudaram com as demais crianças. 
Ana enfrentou momentos de angústia e frustração ao não conseguir desempenhar o atendimento da forma considerada por ela como satisfatória, bem como parece não ter sido acolhida em seu sofrimento naquele momento. Descreve uma experiência muito angustiante com o paciente e, diante disso, vai se isolar no banheiro para chorar.

O relato de Ana possibilita refletir sobre a formação realizada nos cursos da área da saúde no Brasil que, reconhecidamente, ainda está estruturada sob a influência do modelo biomédico e se caracteriza por uma ênfase biologizante e positivista, pautadas na fragmentação do conhecimento, visão dicotômica entre teoria e prática, valorização dos métodos tecnicistas, mecanicistas e passivos de transmissão de conhecimento e um marcado foco na especialização (Braid, Machado, \& Aranha, 2012; Carneiro \& Porto, 2014; Costa \& Borges, 2015).

Nesse cenário, segundo Costa e Borges (2015) e Silva e Santana (2015) os Ministérios da Educação e Saúde vêm reunindo esforços e investimento para uma articulação voltada à reorientação do sistema de saúde brasileiro que, consequentemente, abarca a questão da formação profissional e do paradigma que a norteava, considerando a importância dos profissionais da saúde na consolidação de um novo modelo assistencial. Contudo, apesar de na década de 90 serem observadas importantes iniciativas focadas numa maior articulação entre academia e prática nos serviços de saúde, a maioria das Instituições de Ensino Superior (IES) continuou reproduzindo o modelo tradicional de ensino e formando profissionais para atuar no SUS sob a lógica do modelo biomédico (Batista, 2013; Dias, Lima \& Teixeira, 2013).

Percebe-se a necessidade de que os cursos da área da saúde continuem sendo revistos, visando articular um ensino que consiga suprir as principais demandas presentes na atuação profissional, respeitando as diretrizes do SUS e a individualidade de todos os envolvidos no cuidado. Esse cenário reflete ainda a necessidade de que os alunos não tenham apenas espaços de vivências técnicas, mas que possam ter na academia condições e espaços de diálogo e trocas que facilitem um cuidado também voltado às suas demandas emocionais. Espaços de acolhida que devem ir além de salas ou espaços físicos, que se fundem a partir das relações pessoais e vínculos de confiança e cooperação mútua estabelecidos entre 
colegas e seus professores, para que todos se sintam confortáveis e aptos a cuidar e serem cuidados.

Ainda, ao fim de sua fala, a estudante reafirma duas vezes que está bem e caracteriza o episódio como "um desafio que eu não consegui vencer, mas valeu de experiência" [sic]. A fala da estudante parece remeter a um esforço para significar os momentos de angústia que viveu como algo que lhe acrescentou experiência, mas ao afirmar isso ela parece buscar uma conformação com o desfecho do episódio vivenciado ao invés de problematizar as questões vivenciadas. Essa naturalização pode referendar que não havia mais o que pudesse ser feito para que a aluna tivesse uma experiência com menos sofrimento, quando ela poderia, por exemplo, ter tido acesso a outras estratégias para auxiliá-la no estabelecimento de uma relação interpessoal positiva e na formação de vínculo com a criança. Vivências como a relatada por Ana podem contribuir para que a estudante se sinta impotente frente ao sofrimento presente no atendimento e o relativize, minimizando o impacto dos sentimentos negativos que permeiam sua experiência prática, bem como a vivência da criança em atendimento.

\subsection{Eixo II: Humanização nas Práticas da Clínica-escola: concepções, vivências e desafios.}

Nesse Eixo de Análise, foram agrupados os recortes dos relatos dos graduandos que abordam a humanização a partir das vivências do cuidado em saúde em uma Clínica-escola Odontopediátrica. Os relatos versaram sobre como os estudantes significam os princípios da humanização, a forma que são vivenciados no contexto da Clínica-escola e os desafios enfrentados para a articulação entre formação teórica e prática. Este Eixo foi dividido em dois sub eixos, a saber: " $A$ humanização da prática Odontopediátrica" e "Dificuldades e desafios para a humanização dos atendimentos na Clínica-escola". 


\subsubsection{A Humanização da Prática Odontopediátrica}

O trabalho com crianças envolve a compreensão que o desenvolvimento das mesmas sofre influência de fatores biológicos, emocionais e psicológicos do meio social no qual estão inseridas. O cuidado ofertado a partir dessa visão integral facilita a humanização da atenção em saúde. Nesse contexto, serão discutidos relatos dos participantes acerca do significado de humanização e das características de "modos de ser" humanizados/desumanizados na Clínica-escola.

Ana e Beatriz descrevem em seus relatos aspectos que consideram como uma postura profissional humanizada no atendimento odontopediátrico:

"É... tratar o outro como outro ser humano, do ponto de vista mais amplo da palavra, por que se você trata o outro como objeto de estudo você acaba deixando as emoções de lado, e no processo de humanização você tem que levar em conta as emoções, o ambiente familiar, o ambiente psicológico, o estado emocional, o estado psicológico, você tem que levar em conta o ser humano como um todo, né?! Não só uma parte dele que é a função biológica, e o estado da pessoa... Acho que você tem que levar em consideração todo o aspecto da pessoa. No modelo mais biopsicossocial, mesmo! (...) Você tratar a outra pessoa como uma pessoa... não só como objeto de estudo, não só como objeto de doença que você vai lá e extirpa a doença ou extirpa a lesão... é muito mais fácil você tratar o outro como ser humano, por que ele se sente conectado a você e você ganha o seu paciente".

(Ana, estudante)

"É essencial, eu acho, você não pode tratar aquilo, principalmente uma criança, como se fosse uma boquinha só. Ir lá e fazer o que quiser com ela pra ela fazer o que você pretende. Mas você tem que levar em consideração tudo, inclusive tipo, se a criança tá passando por uma dificuldade, ou entender, saber encaminhar pra um psicólogo ou então pra algum outro tipo de apoio que ela precise. Eu acho que é essencial conversar e ver todos os aspectos possíveis que você consiga perceber. (...) Tratar como uma pessoa (risos), ou... tratar, ver aquilo não como uma boca só, como um dentinho, ver como um inteiro. Não só o problema que ela traz na boca, ver o todo, entender a criança, entender o que ela tá sentindo, entender o que você pode fazer pra ajudar. Acho que, é meio que isso...".

(Beatriz, estudante)

"Bom, eu acho que essa individualização dos pacientes, de você tratar cada paciente como um ser único, um ser que precisa de atenção dedicada, diferenciada é muito importante. E... você trazer esse atendimento aonde você vai dar uma atenção pra conseguir a confiança do paciente... você vai dar uma atenção pra que o paciente confie em você, pra que ele auxilie você no tratamento, é muito, muito, muito mais valioso do que você só aprender a fazer uma restauração, tratar um canal, é mais valioso pra gente. Não só na Odontopediatria, mas como todas as outras disciplinas. Você conseguir lidar com o paciente e saber que ele não é só aquele problema que 
ele tem, ele tem outros problemas, outras coisas envolvidas que a gente tem que saber lidar também."

(Carlos, estudante)

Os estudantes parecem fazer menção a uma concepção de humanização que compreende uma visão integralizante do paciente, considerando "as emoções, o ambiente familiar, o ambiente psicológico, o estado emocional, o estado psicológico, você tem que levar em conta o ser humano como um todo" [sic]. Pode-se dizer que tal olhar ao usuário está relacionado com um dos princípios preconizados pela Política Nacional de Humanização (PNH) (Brasil, 2004), que busca orientar e facilitar aos profissionais um melhor entendimento dos aspectos biopsicossociais para que 0 cuidado parta de um olhar integral ao paciente e considere as singularidades destes como parte do processo saúde-doença (Barbosa et al., 2013).

Acerca do conceito de integralidade, Erdmann, Souza e Mochel (2010) o definem enquanto a dimensão onde as intervenções em saúde são determinadas pelas especificidades dos relacionamentos interpessoais, que se caracterizam como atitudes de interação na relação entre os sujeitos envolvidos, que assim acabam ampliando os olhares sobre a saúde, incluindo e valorizando o diálogo e a escuta. Ainda, a integralidade é defendida pelos autores como fundamental na prática profissional e se expressa através da forma como os profissionais correspondem às necessidades das pessoas atendidas. Portanto, a consolidação de um sistema integral de atendimento em saúde não envolve apenas a aplicação dos saberes técnicos, mas é apreendida como o relacionamento positivo entre profissionais, usuários e instituição, refletido através do tratamento digno e respeitoso, com qualidade, acolhimento e vínculo.

Logo, a integralidade no cuidado só será possível se existirem condições objetivas e intersubjetivas para o diálogo, o vínculo e a solidariedade. Os relatos apontam a incorporação por parte dos estudantes do conceito de cuidado integral, uma vez que destacam a necessidade de um olhar para o outro como um TU, ou seja, numa relação de alteridade que enxerga no outro um semelhante, questão essa fundamental para a humanização em saúde. Por outro lado, cuidar através de atitudes automáticas, com pouca reflexão e muita cobrança pela técnica pode contribuir para um movimento de objetificação do outro, distanciando das perspectivas mais humanas e menos superficiais. 
Ana, ainda, discute sobre a capacidade do Odontopediatra de observar sinais que possam apontar sentimentos que o auxiliem numa conduta que responda às necessidades da criança:

“É... a observação, principalmente. A observação, no aspecto mais amplo mesmo, por
que às vezes a criança chega com uma carinha de assustada, de ansiosa, então você
já percebe isso na criança, você acaba manejando ela de maneira melhor, da maneira
que ela precisa... acaba se envolvendo... ela tá nesse estado emocional de ansiedade,
de medo, você deixa ela respirar, você deixa ela sentir que aquele ambiente não vai
fazer mal a ela, você leva ela em outros equipos pra mostrar que outras crianças
também estão colaborando com o tratamento, que isso não é nenhum bicho de sete
cabeças. Você mostra o bichinho pra ela da cárie desenhado numa agendinha, num
caderninho, num livrinho... você demonstra na prática mesmo, dando o instrumental
na mão da criança, falando '-Olha, a gente vai fazer tal coisa agora. Vai parecer que a
gente tá tirando... com a broquinha, vai parecer que a gente tá fazendo uma
brincadeira no seu dente, mas é só pra tirar o bichinho, o cocôzinho do bichinho. Se
doer, se machucar levanta a mão!'. A maioria dos professores fala assim "não fala que
dói! Não fala que dói senão a criança vai ter dor". E a experiência que eu tenho é o
contrário, toda vez que eu falei 'olha, talvez vá doer' e eu falei isso pra criança antes,
a criança respondeu de maneira real. Ela não falou assim 'nossa, tá doendo!',
nenhuma delas fez isso...". (Ana, estudante)

No relato da estudante é possível identificar uma preocupação em respeitar o tempo e os receios da criança em relação ao tratamento, oferecendo a ela um ambiente acolhedor, a possibilidade de uma experiência de cuidado positiva e, ainda, do estabelecimento de um vínculo de confiança entre as partes envolvidas. Nesse contexto, Mota et. al., (2012) apontam que a criança conhecer melhor o ambiente em que está, as intervenções que serão realizadas, bem como os instrumentos com os quais terá contato, poderá enfrentar melhor tal vivência. Ainda, é responsabilidade do profissional oferecer à criança condições de enfrentar de maneira positiva tal experiência de atendimento odontológico, de modo a ajudá-la a assumir seu lugar de corresponsável pelo cuidado.

Ana segue seu relato descrevendo situações de atendimento que refletem sua postura empática em relação à criança. O cuidado e esforço que a estudante demonstra na tentativa de ambientar seus pacientes da melhor forma possível, traçando estratégias lúdicas e adequadas à idade deles, parecem remeter a um aprendizado em relação à prática odontopediátrica. Mesmo em contexto de avaliação de novas vivências práticas, que são referidos por Cardoso e Loureiro (2008) como 
aspectos potencialmente estressantes, Ana prioriza a utilização de uma abordagem humanizada e empática.

No final do recorte, Ana retoma a orientação de seus professores sobre não dizer para a criança que o procedimento causará dor, pois segundo a aluna, eles orientam que poderia ocorrer a indução da criança a sentir tal desconforto. Então, a estudante busca formar a sua própria visão acerca da situação que vivencia e isso lhe permite relativizar e ponderar a sugestão dos professores, ampliando suas possibilidades de intervenção. Tal flexibilização na aplicação dos conceitos apreendidos na Clínica aponta para um processo de aprendizagem prático que possibilita que a experiência pessoal com os pacientes promova também um aprendizado. Logo, pode-se entender que a estudante ao refletir a partir de sua própria experiência e visão de mundo, encontra caminhos que podem facilitar um encontro com o outro.

Paula refere em sua fala aspectos que remetem à horizontalidade e empatia na atuação prática com os pacientes pediátricos:

"Mais do que se relacionar. Eu acho que é mais, é muito mais que isso. Eu acho que é ter uma relação mesmo com o paciente, de igual pra igual, não ter diferença. Não ter eu tô acima de você... é se relacionar. (...) Acho que é a troca de carinho com o paciente, se colocar no lugar da criança, entendeu?! Perceber os medos que eles tão sentindo... é, feeling, né?!

(Paula, estudante)

O relato da estudante remete ao conceito de horizontalidade que se contrapõe à perspectiva do estabelecimento de relações hierárquicas, onde o profissional se coloca como superior ao paciente, relegando ao usuário a condição de, como o próprio nome revela, paciente, numa relação onde se busca fazer desaparecer a subjetividade do outro para que a subjetividade da doença apareça. Nessa ótica, os papéis tradicionais de "pessoa saudável e doente" são revistos, o que possibilita que todos experienciem a aprendizagem a partir de novos lugares e se percebam na condição de protagonistas, a partir da própria experiência (Ishara \& Cardoso, 2013). Desse modo, Paula ao se colocar numa relação mais horizontal com a criança, possibilita estabelecer uma relação singular e única com cada uma delas, uma vez que valoriza a singularidade, o protagonismo e a subjetividade presentes no encontro com o outro. 
Por outro lado, o recorte abaixo abarca situações consideradas pela estudante como desumanas, em contraponto ao que seria a humanização do atendimento.

“Uma atitude desumana seria você vendo que a criança não quer abrir a boca. Ela
chega na cadeira, senta, não quer abrir a boca. E daí você vai lá, já chama 'Olha, eu
preciso de dois pós (alunos de pós graduação) e um orientador'. Aí vem lá os dois pós
pra conter a criança, o outro segura na cabeça pra você conseguir colocar a rolha na
boca dela. Só pra conseguir colocar a rolha. Imagina, você não tá fazendo nada, só
quer que ela abra a boca. Você consegue conversar com uma criança pra ela abrir a
boca, sabe?! Algumas outras coisas pode ser que não, mas tem que fazer! Mas pra
abrir a boca você não precisa chamar uma equipe, sabe, pra conter ela pra abrir a
boca. Conversa com ela, pede pra mãe vir, senta ali na frente, fala assim '-Olha, eu
vou fazer isso", demonstra, tem tantos jeitos, sabe?! Nossa, tem tanta coisa pra fazer
ao invés de você partir direto pra isso. Às vezes a pessoa fala '-ah não, mas eu
conversei'. Ah, você conversou?! Você falou o que pra ela?! Eu acho que falar '-Eu só
vou olhar. Olha seus dentes como são lindos!', sei lá, dá uma desculpa. Tem tanta
coisa que pode fazer ao invés de partir direto pra essa agressão, sabe?! Por que é
uma agressão, ela vai entender como uma agressão. E daí toda vez que ela vier você
vai ter que fazer a mesma coisa. Então, isso que é desumano. E humano seria o
oposto, né, seria usar todas as alternativas que a gente vê em aula pra convencê-la,
pra explicar...". (Laura, estudante)

Laura descreve uma situação de atendimento com algumas nuances que refletem práticas presentes no cotidiano da Clínica-escola. A estudante argumenta acerca do quanto alguns profissionais estão pouco comprometidos com os esforços para a humanização dos atendimentos, mesmo aqueles que referem ter tentado usar de estratégias para facilitar a vivência do paciente com as intervenções odontológicas. Nesse sentido, é possível observar um movimento consonante ao que Merhy, Feuerwecker e Gomes (2010) chama de cuidado centrado no procedimento, com foco na doença, bem como um distanciamento do cuidado centrado no usuário.

No contexto estudado, as crianças encaminhadas aos atendimentos podem ser expostas a situações potencialmente desconfortáveis, tais como procedimentos invasivos, dor real ou desconforto físico e psicológico (Silva, Moraes \& Rolim, 2008). Situações como essas se configuram enquanto oportunidades para que tanto as crianças quanto seus acompanhantes possam ser estimulados a adquirir e manter comportamentos mais eficazes para lidar com o tratamento, especialmente se for atendidos por profissionais que dominem estratégias de manejo comportamental e cognitivo (Moraes, Costa Júnior \& Rolim, 2004).

Retomando o recorte da fala de Laura, é possível ilustrar através da abordagem utilizada por alguns de seus colegas o quanto é importante o manejo adequado das crianças dentro desse contexto. A forma como o profissional conduz seu atendimento 
e sua relação com a criança tem um papel importante na significação que essa fará de sua experiência no consultório do dentista.

Na situação relatada, Laura elenca várias possibilidades de cuidado para que a contenção física pudesse ser evitada, entre elas a intervenção distrativa. Nesse sentido, Silva, Moraes e Rolim (2008) afirmam que os procedimentos de distração utilizados simultaneamente ao tratamento odontológico podem facilitar o manejo comportamental do paciente e, ainda, contribuir para uma maior colaboração deste na execução dos procedimentos, bem como reduzir sua exposição ao ambiente odontológico que por muitas vezes é ansiogênico.

A técnica de distração pode também ser considerada como estratégia de estímulo para que a criança retire seu foco do procedimento realizado e o direcione a estímulos tidos como mais agradáveis. Quando Laura relata a explicação de um procedimento através do recurso lúdico do desenho como possibilidade interventiva, ela oferece à criança uma nova forma de vivenciar sua experiência com o cuidado em saúde bucal. A linguagem utilizada pela estudante também é uma forma de reconhecer a especificidade do atendimento à criança, uma vez que a mesma necessita de uma comunicação diferenciada e efetiva para conseguir entender e possivelmente colaborar.

A comunicação entre profissionais e pacientes realizada de forma eficaz tem consequências diretas relacionadas à adesão as recomendações e aos cuidados, compreensão acerca das orientações relacionadas ao tratamento, melhoria nos sintomas e respostas fisiológicas, melhor percepção acerca de suporte social, manejo de eventos estressores e uma melhor adaptação aos planos terapêuticos (Coleman, 2002; Darby, 2002; Howells \& Lopez, 2008). Ainda, a interação que ocorre entre profissional e paciente durante as consultas, configura um contexto importante de promoção do desenvolvimento da criança, pois oferece a ela a possibilidade de se colocar diante de temas importantes, como o autocuidado, proteção e fatores psicossociais relevantes.

Segundo Kohlsdorf e Costa Júnior (2013), a literatura indica que a qualidade da comunicação em pediatria influencia de maneira relevante a adaptação dos pais/acompanhantes ao tratamento, sendo a mesma um elemento imprescindível para um processo terapêutico eficiente. Crossley, Eiser e Davies (2005), DiMatteo (2004), Howells e Lopez (2008) e Nobile e Drotar (2003) afirmam que a qualidade das informações prestadas pelos profissionais de saúde tem relação direta com o 
autocuidado, entendimento acerca do diagnóstico e tratamento, manejo dos fatores psicossociais, satisfação com o serviço, melhor apreensão das explicações e menos retornos aos serviços.

Nesse contexto, estudos científicos da formação médica apontam que a formação em saúde não inclui um treinamento satisfatório sobre a interação desses profissionais com as crianças durante os atendimentos pediátricos. A pesquisa conduzida por Dubé, LaMonica, Boyle, Fuller e Burkholder (2003) apontou a insuficiência da prática de comunicação durante a formação acadêmica de residentes. Mais da metade dos profissionais participantes do estudo não observou qualquer consulta de paciente pediátrico e $12 \%$ dos participantes referiram a ausência de treino formal para desenvolver habilidades de comunicação com essa clientela. Outro estudo realizado por Rider, Volkan e Hafler (2008) aponta para a importância de abordar na graduação o treinamento das habilidades de comunicação com os pacientes pediátricos. Poucos participantes do estudo referiram ter recebido durante a formação elementos para se qualificarem nesse sentido.

A partir da análise dos relatos dos estudantes, pode-se inferir que as habilidades necessárias para se relacionarem com as crianças e com a subjetividade presente nessa relação ficam quase que exclusivamente sob responsabilidade do próprio aluno, ampliando as inseguranças e medos próprios dos primeiros atendimentos profissionais.

\subsubsection{Dificuldades e Desafios para a Humanização dos Atendimentos na Clínica- escola}

Um dos grandes desafios existentes no ensino da Odontologia é responder à necessidade de uma formação que ofereça treinamento prático e técnico aos estudantes, ao mesmo tempo em que supra as demandas dos usuários e suas necessidades em saúde, bem como a formação ética e humanizada dos profissionais (Tiedmann et. al., 2005). Nesse sentido, faz-se importante a investigação acerca dos avanços e dificuldades na construção de uma formação profissional comprometida com os preceitos éticos e basilares da profissão, para que as possibilidades de melhorias sejam apontadas a partir do respaldo científico. 
Nesse sub eixo, foram discutidos a partir do processo de ensino-aprendizagem, fatores que, na avaliação dos estudantes não favorecem a humanização das práticas. Os entrevistados relataram suas dificuldades em compreender as contradições que se revelam na articulação entre os diferentes objetivos definidos para a dinâmica de funcionamento da Cínica-escola, o método de avaliação ao qual são submetidos, a postura profissional de alguns supervisores que atuam nesse contexto, dentre outras questões.

Ana discute em seu relato as dificuldades para se manter condutas humanizadas dentro da Clínica-escola, a partir da observação dos profissionais na abordagem das crianças:

"É difícil o processo (de humanização), mas assim, não é impossível, é possível desde que todo mundo esteja consciente do processo de humanização, do quanto isso é importante, não só com relação ao paciente mas dos professores com os alunos, dos professores com os pacientes. Que tinha muito professor que sentava lá na cadeira, nem falava oi pro paciente, falava assim 'Ai, abre a boca!' e já ia fazendo o procedimento, sabe?! Não se apresentava, não falava o nome, não perguntava o nome da mãe ou do responsável que tava do lado, e isso é importante, né?! Falar com a pessoa 'Olha, a gente vai fazer tal procedimento agora, tá, ela te explicou, a aluna te explicou direitinho como é que é?'. Aí as vezes a criança falava sim, as vezes a criança falava não e dependia do professor também. Que nem a Maria (nome da professora) sempre fazia isso, ela só quando tava muito apressada que ela só sentava e fazia. $A$ Professora tinha uma abordagem diferente, ela chegava e falava 'Oi, tudo bem? Oh, vou fazer tal coisa!', só que não demonstrava, não mostrava pra criança nada, só ia lá, fazia e ia embora! Então não só na Odontopediatria que tinha que ter esse procedimento de humanização, mas em todas as outras clínicas".

(Ana, estudante)

A estudante, apesar de reconhecer as incoerências que emergem no contexto da Clínica-escola quanto à aplicação dos conceitos de humanização, aponta a prática humanizada como algo possível desde que os profissionais estejam conscientes de sua importância. Esse aspecto levantado por Ana está presente na Política Nacional de Humanização (Brasil, 2004), que orienta e ressalta a importância de que todas as pessoas envolvidas na rede sejam cuidadoras e cuidadas, que a humanização se faça presente não apenas no relacionamento entre profissional de saúde e paciente, mas que permeie todas as relações existentes dentro do contexto do cuidado.

As relações estabelecidas entre os professores, os supervisores e pacientes podem ser apreendidas pelos estudantes como um modelo de atuação, visto que eles estão em processo de formação profissional e, em muitos casos, buscam uma 
ampliação de repertório para lidar com suas experiências de atendimento. Estudos na área da Odontologia apontam o professor como figura essencial dentro do processo de ensino-aprendizagem, podendo este contribuir positiva ou negativamente, a depender da postura adotada e das experiências compartilhadas (Raldi et al., 2003; Lazzarin, Nakama, Cordoni Júnior, 2007).

Acerca disso, podem ser identificados no relato de Ana elementos que apontam um olhar crítico sobre a atuação dos profissionais de referência que atuam na ClínicaEscola. A estudante descreve algumas abordagens feitas com as crianças no atendimento odontológico que sugeriu que ela definiu critérios pessoais para uma comparação entre posturas humanizadas e não humanizadas. Assim, infere-se que a estudante tem como anti modelo de atuação as posturas desumanizadas e a percepção de tais abordagens, a partir dessa ótica, pode ajudá-la a não aplica-las em sua prática. Ainda, Ana parece avaliar a prática profissional de seus professores com um olhar voltado ao gesto deles, percebendo a necessidade de que esse seja ampliado em determinados momentos para melhor atender os pacientes.

Júlia, em seu relato aponta contradições entre "ensinar" humanização e "praticar" condutas humanizadas:

"Ai, não tem muito (humanização)! É bem teórico o que a gente tem sobre isso. $A$ prática não bate com a teórica, por que a gente veio pra clínica e a gente teria que gastar uma ou duas seções pra conhecer o paciente, pro paciente te conhecer também, e aí a anamnese que você faz com a mãe, no mesmo dia a gente tem que fazer a profilaxia e o exame que é pra ver se precisa de algum tratamento ou não. Então eles mesmos falam 'viu, acelera!'”.

(Júlia, estudante)

"A prática deveria ser fiel à teórica. Eu acho que a gente aprende a humanização aqui em outras disciplinas também, por isso que a gente já traz na bagagem um pouquinho do que deveria ser o atendimento, mas ela não existe! (...) E são dessas disciplinas que a gente traz. Na endodontia não teve. Nem o professor sabe nada sobre humanização (risos!). Com humanização a gente consegue ter um atendimento bem melhor pro paciente, a gente consegue ver que o paciente acaba confiando mais. $\mathrm{Na}$ endodontia não dá tempo de ter isso, tem que bater meta também. E na pediatria que é um dos que mais deveria ter, não tem".

(Júlia, estudante)

Para Júlia o que é ensinado sobre humanização dentro do percurso de formação acadêmica em Odontopediatria permanece no plano teórico e acaba não perpassando a prática. Ela chama a atenção para a necessidade da ambientação da 
criança com a situação do tratamento, que deveria ser feita nos primeiros atendimentos, para que a criança se familiarizasse com o ambiente, o profissional e os procedimentos. Mas, ao invés disso, os alunos já iniciam com exames clínicos para delinear as necessidades odontológicas da criança. Nesse momento, segundo a estudante, os próprios professores sugerem aos alunos que façam o atendimento de forma mais rápida, dizendo "acelera!" [sic].

Silva, Moraes e Rolim (2008) apontam que no atendimento à criança, os primeiros contatos positivos com o profissional e com sua vivência dessa experiência podem contribuir ou dificultar a sua cooperação no tratamento e que o cuidado voltado a essa clientela sofre o impacto da escassez de ambientes adequados e das relações hierarquizadas, que contribuem para um distanciamento da perspectiva da criança enquanto ser integral. Ainda, percebe-se nesse contexto a persistência do modelo biomédico que é refletido nas consultas voltadas às queixas e no comprometimento da acolhida desses pacientes (Monteiro et. al., 2012).

Pode-se perceber que, de acordo com o relato de Júlia, falta tempo para atender adequadamente os pacientes pediátricos de forma a responder as suas necessidades em saúde, preparando-os para o tratamento, esclarecendo as suas dúvidas e estabelecendo um vínculo que auxilia no andamento do atendimento, em virtude dos objetivos do ensino. A aluna descreve que há pouca atenção em relação ao preparo prévio desses pacientes para entrarem em contato com essa nova vivência que, para muitas crianças, é permeada pelo medo e fantasias assustadoras. Esse contexto e modo de atuação podem contribuir para que os estudantes reproduzam em suas práticas posturas com maior ênfase nos procedimentos e com pouca valorização do acolhimento e formação de vínculo, comprometendo o engajamento desses na luta pela humanização do cuidado e dos serviços.

Júlia relata ainda que, em algumas outras disciplinas, foram trabalhados conteúdos acerca das políticas de humanização e que pôde se apropriar do conhecimento para atuar com as crianças. Também, refere que com o conhecimento das técnicas odontológicas e dos aspectos relacionados à humanização seria possível realizar atendimentos melhor qualificados e mais pautados no vínculos estabelecidos. Por fim, relata que embora a pediatria seja a área da Odontologia que mais deveria ser humanizada, não é o que acontece no contexto estudado. 
Jorge e Júlia apontam a dinâmica de trabalho na Clínica-escola e a forma de avaliação a qual são submetidos como fatores que dificultam a oferta de atendimento humanizado:

"Sempre que eu precisei atender os pacientes a gente tentou ser o mais humano possível. E isso acho que nunca poderia deixar de acontecer. Talvez falte tempo na clínica pra gente conseguir conversar com o paciente, com os pais, fazer uma melhor adaptação dele ao ambiente. Mas eu vejo também as dificuldades, por que eles precisam ter produção, eles querem que a gente saia com um bom treinamento".

(Jorge, estudante)

"A gente tenta. Eu acho que fora daqui a gente consegue, entendeu?! Mas aqui a gente precisa ser rápido, ser mais dinâmico pra entregar alguma coisa no fim do semestre. (...)Aqui, é mais, assim, uma questão de pontuação mesmo. De ter que entregar, por exemplo, um isolamento (procedimento odontológico) não vale nenhum ponto. (...) você tinha uma cobrança, ali, de entregar ponto e tal e... não tinha humanização nenhuma!

(Júlia, estudante)

"Falta bastante humanização nesse aspecto aqui dentro. (...) Eu acho que parte bastante do aluno querer ter essa conduta humanizada, mas ele acaba não tendo tempo pra isso, não tem espaço mesmo. Tem que entregar ponto, tem que acabar o caso pra começar outro... não tem muito tempo pra isso".

(Júlia, estudante)

A estudante relata aspectos do funcionamento e da dinâmica da Clínica-escola na qual estava inserida, identificando que era mais exigida em relação à realização de procedimentos, comprometendo o tempo dedicado à produção de vínculo e cuidado. Vale ressaltar que tais procedimentos são pontuados quantitativamente e os estudantes que não atingem a meta estipulada são reprovados ao final do semestre.

Com pouco tempo para manejar os imprevistos e com a cobrança pela excelência técnica, os estudantes muitas vezes se veem obrigados a escolher a melhor forma de aproveitar seu tempo: se praticando o maior número possível de procedimentos e para isso dar pouca atenção à humanização, ou se dedicando mais tempo à preparação adequada das crianças mesmo que isso comprometa a avaliação quantitativa ao final da disciplina. Esse tipo de avaliação pode induzir os estudantes a uma priorização dos procedimentos em detrimento do cuidado e da atenção aos aspectos humanísticos existentes nessa prática.

$\mathrm{Na}$ perspectiva dos participantes do estudo, o sistema de avaliação e o processo ensino-aprendizagem no contexto estudado contribuem para que os 
estudantes optem por focar sua prática nos procedimentos e na busca pela qualificação técnica com pouco incentivo aos preceitos da Política Nacional de Humanização. As Diretrizes Curriculares Nacionais do curso de graduação em Odontologia destacam a Humanização da Educação como um dos aspectos fundamentais para a concretização de novas bases para a Educação Superior, pois coloca o homem como o centro do processo de construção da cidadania, comprometida e integrada à realidade social e epidemiológica, às políticas sociais e de saúde, oportunizando a formação profissional contextualizada com os reais problemas brasileiros, e a busca de soluções que possam transformar as condições de saúde (Brasil, 2007).

Construir projetos pedagógicos e implementar disciplinas práticas humanizadas são desafios para as Instituições de Ensino Superior, responsáveis pela formação dos profissionais da saúde. Assim, no ensino odontológico, o objetivo do atendimento de pacientes nas Clínicas-escolas precisa responder à necessidade da formação e do treinamento prático e técnico dos alunos, sem excluir o ideal ético de suprir as necessidades de saúde e demandas pessoais dos usuários, bem como a formação humanizada dos profissionais.

É esperado da formação desses profissionais, além dos saberes técnicos, que ela aborde a inclusão de aspectos referentes aos determinantes sociais, culturais, psicológicos, éticos e legais envolvidos nos níveis individuais e coletivos do processo saúde-doença. Ainda, ressalta-se nas Diretrizes Curriculares Nacionais dos cursos da área da saúde, a importância de se trabalhar não apenas os conteúdos técnicos e cognitivos, mas também estimular o desenvolvimento de habilidades emocionais, motoras e sociais. Com isso, destaca-se a importância de que se utilize de estratégias educacionais ativas, centradas no aluno como sujeito do processo de ensino/aprendizagem e a diversificação desse cenário visando a articulação entre teoria e prática, bem como entre ensino, pesquisa, extensão e assistência (Costa \& Borges, 2015; Hora \& Souza, 2015; Moreira \& Dias, 2015; Silva \& Santana, 2015).

Rosito e Loterio (2012) apontam que o processo de formação do profissional de saúde necessita resgatar a dimensão humana, visando a integralidade no desenvolvimento do ser humano. As autoras afirmam ainda que o esvaziamento do sentido do que é humano no contexto de formação em saúde, contribuiu para que a 
atuação desses profissionais fosse reduzida a um ato meramente mecânico, distanciando-se dos sentidos que qualificam um encontro entre pessoas. Assim, para a construção e manutenção do cuidado humanizado, faz-se necessário que haja um processo de formação que abarque a subjetividade presente no encontro profissional/paciente, que estimule 0 desenvolvimento da sensibilidade, 0 amadurecimento emocional e ainda a manutenção de maneiras positivas de ser e se relacionar com o outro.

Lucas e Jorge também relatam algumas dificuldades para humanização que estão relacionadas à dinâmica de funcionamento da Clínica-escola:

"Então, se a gente ficasse usando algumas clínicas pra ficar só conversando, a gente atenderia menos pacientes, a gente atenderia menos casos, a gente poderia sair daqui sem ter feito uma endodontia, por exemplo. Aí isso seria uma coisa ruim. Então acho que eu atribuiria (as dificuldades de humanização) à clínica mesmo, né?! A quantidade de pacientes que a gente tem e a quantidade de coisas que a gente tem que fazer".

(Lucas, estudante)

"Pela pressa e pela quantidade de pacientes o professor não pode ficar em cima toda hora de todos os alunos, então eu acho que (a humanização) é regular, sabe?! Não é tão boa assim... (...) se tivessem menos alunos aí acho que seria melhor".

(Lucas, estudante)

“(...) o importante é tentar compreender a criança, a história de vida dela, eu acho que é o primordial, e tentar levar isso durante o atendimento. (...) gostaria de ter mais tempo. O tempo que a gente teve foi o suficiente pra fazer os procedimentos e a gente tentava entre esse tempo entender, conversar, contar o que acontece., escutar o que a criança tinha pra contar, como foi a escola. Mas era um tempo curto, não era um tempo que eu tinha, assim, pra sentar e ficar ouvindo. Então era entre os procedimentos. Acabou um procedimento ela vai contando enquanto você vai lavando um instrumento pra buscar outro (paciente) pra continuar o atendimento. Não era um tempo em que a criança sentava e ficava ali contando, não! Era um tempo entre os atendimentos".

(Jorge, estudante)

Para Lucas, se os alunos optassem por usar mais tempo dos atendimentos para conversar com as crianças isso faria com que eles atendessem menos casos e, assim, poderiam sair da Faculdade sem ter realizado algum procedimento técnico importante, o que, em sua opinião, seria prejudicial à formação profissional. Ele compreende que a quantidade de pacientes e de procedimentos a serem realizados como uma dificuldade para humanização, embora ache que "se alguém quisesse pegar e ficar só falando com o paciente poderia. Eu que não quis." [sic]. Nesse 
contexto, o estudante não enxerga possibilidade de ofertar um cuidado integral, mantém uma postura dicotômica fragmentando o trabalho e produzindo um cuidado mecanizado (Merhy et. al., 2010). Ele avalia a aplicação dos princípios de humanização como regular e "não tão boa assim" [sic] devido à pressa, quantidade de pacientes e à impossibilidade dos professores acompanharem todos os alunos de perto e, por fim, refere que se houvessem menos alunos na Clínica a aprendizagem teria um melhor aproveitamento.

O estudante aborda questões que também estão presentes nos relatos anteriores de Jorge e Júlia, que apontam e reforçam a existência de dificuldades para atuar de forma humanizada na Clínica-escola. Tais dificuldades apontadas por Lucas parecem refletir tanto uma consequência da estrutura de funcionamento do local pesquisado, quanto um movimento pessoal do estudante de foco maior em sua preparação técnica. Ao falar da utilização do tempo de atendimento para ficar "só conversando" [sic] com o paciente, o estudante parece minimizar ou até mesmo banalizar a importância desse momento inicial para a produção de vínculo e para um melhor engajamento da criança no tratamento.

Os aspectos relacionais envolvidos no atendimento são apontados por Merhy (1998) como fundamentais para se desenvolver uma atenção de qualidade à saúde, articulando os avanços tecnológicos com o vínculo positivo de relacionamento. Nesse sentido, Deslandes (2004) enfatiza que "obviamente não se muda uma cultura de assistência unicamente com capacitações dirigidas aos profissionais. Mas, certamente, um investimento sério na formação (inclusive deste a graduação) pode, de fato, fortalecer ideias outrora consideradas utópicas ou fora do âmbito da assistência" (p.12).

Desse modo, pode-se apontar a necessidade de revisão constante das estratégias aplicadas nos cursos de graduação visando abarcar a subjetividade presente no processo de ensino-aprendizagem e na relação profissional-paciente. Apesar dos avanços logrados, é preciso que haja uma atenção constante e uma autocrítica por parte de todos os envolvidos no processo formativo dos cirurgiões dentistas para identificar e buscar soluções para as dificuldades encontradas na consolidação de um ensino integralizante. 
O Caderno HumanizaSUS (Brasil, 2010) aponta que a renovação da formação em busca do comprometimento com a humanização vai além da oferta de modelos político-pedagógicos ideais, abstratos e dissociados do cotidiano dos processos de trabalho em saúde. Nesse sentido, almeja-se que a formação em saúde seja pautada por princípios e métodos que enfatizem a indissociabilidade entre formação, cuidar, gerir e tratar. Ressalta-se ainda o potencial da formação para facilitar a abertura a novas sensibilidades que expressam o caráter multifatorial no qual estão envolvidas as práticas de cuidado em saúde. Assim, pode-se apontar que humanizar as práticas em odontopediatria é um processo mais amplo, que deve ser estimulado durante toda a formação desses profissionais que, chegando ao mercado de trabalho, possam se valer de vivências para o desenvolvimento da sensibilidade no encontro com o outro.

Tal dicotomia no discurso dos estudantes ilustra o quanto o processo de formação em Odontologia, ainda está centrado nos princípios de uma cultura técnicocientífica. Por mais que reconheça a importância de uma escuta qualificada, o estudante desvaloriza o diálogo entre profissional-paciente. Pode-se pensar que o estudante sobrevaloriza a técnica e a doença em detrimento da sensibilidade, da produção do vínculo e do cuidado. Nesse sentido percebe-se a prática sendo entendida enquanto uma mera aplicação de conhecimento, onde a competência tornase um atributo individual vinculado ao domínio de habilidades (Brasil, 2010).

Ainda, a interferência nos modos de atuar no contexto da saúde através da formação, implica numa construção de redes que potencializem movimentos de mudança através da problematização dos modos de cuidar e gerir e da experiência concreta dos coletivos estimulando a criação de novos outros modos possíveis, mantendo sempre ativo o movimento entre problematização e ação (Brasil, 2010). 


\section{CONSIDERAÇÕES FINAIS}

O presente estudo teve como objetivo a compreensão das vivências de graduandos de Odontologia frente ao tratamento Odontopediátrico realizado numa Clínica-escola, sob a perspectiva da humanização dos serviços prestados e das relações estabelecidas nesse contexto. A apreensão dessas questões se faz importante na medida em que pode contribuir para uma melhor leitura do impacto desse percurso na formação e prática profissional dos futuros cirurgiões dentistas. As experiências relatadas ocorreram dentro do contexto de atendimento à criança, sendo esse período um recorte do processo formativo dos participantes. Logo, os resultados obtidos podem facilitar o entendimento de algumas nuances próprias dessa especialidade.

Os dados obtidos no estudo apontaram para uma trajetória permeada por dificuldades de diversas naturezas, desde aspectos pessoais dos participantes para lidar com as demandas específicas desse contexto até problemas relacionados à própria dinâmica de funcionamento da Clínica-escola na qual atuavam. Algumas especificidades relacionadas à imprevisibilidade do comportamento das crianças foram apontadas como elementos que dificultaram a atuação, exigindo dos estudantes um esforço maior para repensar e readaptar suas estratégias de intervenção.

Neste contexto, pôde-se perceber que alguns alunos tiveram mais facilidade que outros nessa adaptação, tendo em vista experiências pessoais anteriores de convivência com crianças no âmbito familiar ou mesmo a afinidade que alguns tinham na relação com essa clientela e com essa especialidade de atuação. Alguns dos estudantes que não se identificavam com a Odontopediatria reproduziram em suas práticas um enfoque biologizante de atuação, com pouca atenção às particularidades de cada criança atendida, configurando-se assim a identificação com a área um aspecto positivo para o envolvimento dos alunos na promoção de um cuidado integral em saúde.

Alguns participantes apesar de relatarem estratégias que remeteram a uma dedicação em relação a humanização das práticas, não conseguiram aplicá-las de forma eficiente o que contribuiu para experiências de sofrimento por parte dos 
estudantes e das crianças. O olhar diferenciado a essa clientela se faz necessário para a formação de um vínculo de confiança que contribua para que o tratamento se desenvolva com menos sofrimento para os envolvidos. O relacionamento com os acompanhantes também foi apontado como uma dificuldade nesse contexto. Alguns dos alunos tiveram dificuldade em reconhecer a mãe/acompanhante como alguém que faz parte do atendimento odontopediátrico, e significaram a presença dessas pessoas como um aspecto que influenciou negativamente o andamento dos trabalhos. Considerando a idade das crianças e que a responsabilidade pelas mesmas é do cuidador-adulto (pai e mãe) o atendimento à mesma implica na relação com a díade. Entretanto, destaca-se que os estudantes, em geral, são pessoas de pouca idade, que estão realizando os primeiros atendimentos clínicos, sendo avaliados pelos mesmos e que vão se relacionar com o cuidador-adulto, geralmente a mãe da criança, com pouca capacidade para estabelecer uma relação de cooperação e troca. Parece que, nesse contexto, o cuidador é visto pelo estudante, como mais um adulto para avaliar e criticar o trabalho que vem sendo desenvolvido por ele. Os questionamentos do cuidador, acerca dos procedimentos que estão sendo realizados, são vistos pelos estudantes como dúvidas em relação a sua competência profissional. Pode-se notar a necessidade de se trabalhar as relações com o cuidador e os significados atribuídos as mesmas, visando que processo de formação abarque a integralidade do atendimento à criança.

Os participantes relataram dificuldades para estabelecer uma relação de ajuda com os acompanhantes e pareceram não estar muito familiarizados com essas questões e com a sensibilidade necessária para o entendimento dos diferentes contextos que essas famílias podem estar inseridas.

Outro aspecto ressaltado pelos participantes foi a pouca articulação entre teoria e prática, principalmente, em relação à humanização do atendimento à criança. Foi relatada uma distância entre as orientações e indicações de atitudes tidas como facilitadoras e a aplicação dessas, muitas vezes dificultadas pelo pouco tempo disponível para uma preparação das crianças recém-chegadas para atendimento na Clínica-escola. Foi possível perceber um empenho dos estudantes visando estabelecer vínculo com a criança e acompanhante, bem com realizar a ambientação dos pacientes ao contexto da clínica. Entretanto, como essa é uma abordagem que 
demanda tempo, muitos deles optaram por focar no treino técnico e assim passaram a ter uma dedicação maior aos aspectos biomédicos dos atendimentos.

Em contrapartida, outros estudantes relataram perceber a importância do estabelecimento do vínculo e de uma ambientação dos pacientes à clinica e tentaram se voltar para as demandas comportamentais e emocionais das criançasacompanhantes. Nesse sentido, percebe-se que existe um movimento interno de cada um deles voltado à priorização ou não dessas questões. Entretanto, ressalta-se que a oferta de um cuidado integral e humanizado é parte necessária da formação profissional e assim, responsabilidade das instituições educativas, não podendo ficar na dependência da capacidade pessoal de cada estudante.

Outro dado obtido na pesquisa está relacionado aos sentimentos que a prática odontopediátrica evocou nos estudantes. A maioria dos participantes relatou ter vivenciado sentimentos negativos durante o percurso de aprendizado. Alguns desses sentimentos estiveram relacionados às dificuldades que as especificidades desse tipo de atendimento demandaram, aos relacionamentos interpessoais mantidos nesse contexto, à frustração por não atingir a expectativa pessoal de sucesso nos atendimentos e nas relações com as crianças/acompanhantes, a pouca acolhida as suas demandas emocionais, dentre outras questões.

Nesse sentido, e após discussão dos dados obtidos, foi possível compreender a vivência prática da disciplina de Odontopediatria como uma experiência capaz de demandar um preparo diferenciado dos estudantes para lidar com as questões comportamentais e afetivas das crianças, com os episódios de frustração por muitas vezes não conseguirem atender a essas demandas e, ainda, com os diferentes tipos de relações existentes na Clínica-escola. Pôde-se perceber a necessidade de uma atenção à saúde mental desses estudantes, bem como de uma análise sobre acerca do processo de ensino-aprendizagem desses jovens no o curso de Odontologia.

Acerca dos desafios e dificuldades para a humanização foi possível constatar que no contexto estudado ainda existe uma dificuldade em conciliar o treinamento técnico e prático dos estudantes com uma formação humanizada. A dinâmica de funcionamento da Clínica-escola, principalmente no que diz respeito à avaliação quantitativa de procedimentos realizados pelos alunos foi apontada pela maioria dos estudantes como um fator de impacto negativo para a humanização das práticas. 
Segundo os participantes, a necessidade de se atingir uma meta preestabelecida de procedimentos técnicos acaba induzindo a priorização da realização dos procedimentos mesmo quando as crianças não são cooperativas.

Aponta-se que reduzir o cuidado em saúde aos procedimentos técnicos realizados, reduz as possibilidades de atuação e de compreensão acerca do processo saúde-doença. Desse modo, o olhar integral à criança que chega ao serviço de odontopediatria é imprescindível para um melhor entendimento do seu histórico de vida e contexto na qual está inserida, considerando que esse cuidado vai além de tratar apenas as urgências em saúde bucal. É acolher o paciente em sua totalidade, respeitando suas singularidades e necessidades.

Analisando-se alguns limites do presente estudo ressalta-se que este foi realizado em uma Faculdade Odontologia do interior de São Paulo, entrevistando estudantes desta unidade de ensino, mas apesar dessas limitações considera-se que o estudo realizado traz elementos capazes de contribuir para reflexões acerca da complexidade envolvida nos atendimentos clínicos à criança. Foram abordados aspectos que circundam o percurso de formação desses alunos, permeado muitas vezes por angústias e sentimentos negativos relacionados a episódios significados por eles como situações ansiogênicas e de fracasso. Em muitos momentos, as questões acadêmicas, apontadas pelos estudantes como difíceis de serem elaboradas, passaram a interferir em aspectos como autoimagem, desempenho escolar e até bem estar social com impacto sobre a saúde mental dos participantes.

Diante desse cenário complexo em que se mostrou o da formação em Odontopediatria, aponta-se a necessidade de novos estudos que acompanhem os atendimentos realizados, de forma longitudinal, buscando apreender a dinâmica envolvida nas relações entre professores-estudantes-crianças-acompanhantes. Tais dados poderão favorecer o aprofundamento relativo às questões que envolvem o cuidado humanizado no campo da Odontopediatria. 


\section{REFERÊNCIAS}

Almeida, A. P. (2009). História e Evolução: passo a passo da Odontologia. In: Conselho Reginal de Odontologia do Rio de Janeiro. 125 anos de autonomia da Odontologia no Brasil. Revista CRO-RJ. 10: 10-2.

American Academy of Pediatric Dentistry. (2015). Guideline on behavior guidance for the pediatric dental patient. Reference Manual. 37(6), 15-16.

Ayres, J.R.C.M. et al. (2003). O conceito de vulnerabilidade e as práticas de saúde: novas perspectivas e desafios. In: Czeresnia, D.; Freitas, C.M. (Orgs.). Promoção da saúde: conceitos, reflexões, tendências. Rio de Janeiro: Fiocruz, p.116-39.

Ayres, J. R.; Paiva, V.; Buchalla, C. M. (2012) Direitos humanos e vulnerabilidade na prevenção e promoção da saúde: uma introdução. In: Paiva, V.; Ayres, J. R.; Buchalla, C. M. (Org.). Vulnerabilidade e direitos humanos: prevenção e promoção da saúde: da doença à cidadania. Curitiba: Juruá. p. 9-22. (Livro 1).

Ayres, J. R.; Paiva, V.; França Júnior, I. (2012). Conceitos e práticas de prevenção: da história natural da doença ao quadro da vulnerabilidade e direitos humanos. In: Paiva, V.; Ayres, J. R.; Buchalla, C. M. (Org.). Vulnerabilidade e direitos humanos: prevenção e promoção da saúde: da doença à cidadania. Curitiba: Juruá, p. 43-94. (Livro 1).

Barbosa, G. C.; Meneguim, S.; Lima, S. A. M.; Moreno, V. (2013). Política Nacional de Humanização e formação dos profissionais de saúde: revisão integrativa. Revista Brasileira de Enfermagem, 66(1),123-127.

Bardin, L. (1977). Análise de conteúdo. Lisboa: Edições 70.

Barros, J. A. C. (2002). Pensando o processo saúde-doença: a que responde o modelo biomédico? Saúde e sociedade,11(1), 67-84.

Barros, L. F. F., \& Gondim, D. S. M. (2014). Integralidade na assistência em saúde: desafios e impasses. Revista Científica da FMC, 9(2), 15-24. Recuperado de http://www.fmc.br/revista/V9N2P15-24.pdf.

Batista, C. B. (2013). Movimentos de reorientação da formação em saúde e as iniciativas ministeriais para as universidades. Barbaroi, (38), 97-125. Recuperado de http://pepsic.bvsalud.org/scielo.php?script=sciarttext\&pid=S0104-6578201 3000100007\&lng=pt\&tIng=pt.

Biernacki, P., Waldorf, D. Snowball Sampling: Problems and techniques of Chain Referral Sampling. (1981). Sociological Methods \& Research, 2(11), 141-163.

Botti, S. H. O., Rego S. (2010). Processo ensino-aprendizagem na residência médica. Rev Bras Educ Med., 34(1),132-40.

Braid, L. M. C., Machado, M. F. A. S., \& Aranha, A. C. (2012). Estado da arte das pesquisas sobre currículo em cursos de formação de profissionais da área da saúde: um levantamento a partir de artigos publicados entre 2005 e 2011. Interface Comunicação, Saúde, Educação, 16(42), 679-692. doi: 10.1590/S141432832012000300008 
Brasil. (2002). Ministério da Educação. Diretrizes Nacionais do Curso de Graduação em Odontologia. Resolução CNE/CES 3, de 19 de fevereiro de 2002. Diário Oficial da União. 4 de março de 2002, seção 1, p. 10.

Brasil. (2004) HumanizaSUS: Política Nacional de Humanização: a humanização como eixo norteador das práticas de atenção e gestão em todas as instâncias do SUS / Ministério da Saúde, Secretaria Executiva, Núcleo Técnico da Política Nacional de Humanização. - Brasília: Ministério da Saúde. Secretaria-Executiva. Núcleo Técnico da Política Nacional de Humanização.

Brasil. (2006). Ministério da Saúde. Organização Panamericana de Saúde. Técnica de Desenvolvimento de Sistemas e Serviços de Saúde. A política nacional de saúde bucal do Brasil: registro de uma conquista histórica. Brasília: Ministério da Saúde.

Brasil. (2007). MEC ME. Programa nacional de reorientação da formação profissional em saúde - pró-saúde: objetivos, implementação e desenvolvimento potencial Brasília: Ministério da Saúde.

Brasil. (2008) Ministério da Saúde. Humaniza SUS: Documento base para gestores e trabalhadores do SUS. 4 ed. 1a reimpressão, Série B, Textos Básicos de Saúde. Secretaria de Atenção à Saúde. Núcleo Técnico da Política Nacional de Humanização Brasília.

Brasil. (2010). Ministério da Saúde. Secretaria de Atenção à Saúde. Política Nacional de Humanização. Formação e intervenção / Ministério da Saúde, Secretaria de Atenção à Saúde, Política Nacional de Humanização. - Brasília : Ministério da Saúde. 242 p. (Série B. Textos Básicos de Saúde) (Cadernos HumanizaSUS; v. 1).

Brasil. (2012). Resolução 466/2012. Diretrizes e normas regulamentadoras de pesquisa envolvendo seres humanos. Brasília: Conselho Nacional de Saúde.

Brasil. (2013). Ministério da Saúde. Secretaria de Atenção à Saúde. Política Nacional de Humanização. 1ed. Brasília: Ministério da Saúde.

Brasil. (2016). Resolução 510/2016. Diretrizes e normas regulamentadoras de pesquisa envolvendo seres humanos, aplicáveis a pesquisas em ciências humanas e sociais. Brasília: Conselho Nacional de Saúde.

Camargo Jr., K. R. (1992). (Ir)racionalidade medica: os paradoxos da clinica. Physis: Revista de Saúde Coletiva, 2(1), 203-230.

Canalli, C. S. E., Silveira, R. G., Miasato, J. M., Chevitarese, L. (2012). Humanização na relação cirurgião-dentista-paciente. Rev. Odontol. Univ. Cid. São Paulo, 24 (3), 220225, Set-Dez.

Canguilhem, G. (1990). O normal e o patológico. 3a ed. Rio de Janeiro: Forense Universitária. 
Cardoso, C. L., Ishara, S. (2013). Grupo Comunitário de Saúde Mental: uma análise fenomenológica. In S. Ishara, C. L. Cardoso, \& S. R. Loureiro (Orgs.), Grupo Comunitário de Saúde Mental: Conceito, delineamento metodológico e estudos (pp. 43-91). Ribeirão Preto, SP: Nova Enfim Editora.

Cardoso, C. L; Loureiro, S. R. (2008). Estresse e comportamento de colaboração em face do tratamento odontopediátrico. Psicologia em Estudo, 13(1), 113-141, jan./mar.

Carneiro, L. A., Porto, C. C. (2014). Saúde mental nos cursos de graduação: interfaces $\mathrm{com}$ as diretrizes curriculares nacionais e com a reforma psiquiátrica. Cadernos Brasileiros de Saúde Mental, 6(14), 150-167. Recuperado de http:// incubadora.periodicos.ufsc.br/index.php/cbsm/article/view/1666/3944

Casate, J. C.; Corrêa, A. K. (2012). A humanização do cuidado na formação dos profissionais de saúde nos cursos de graduação. Revista da Escola de Enfermagem da USP, 46(1), 219-26.

Coleman, W. (2002). Family-focused pediatrics: A primary care family systems approach to psychosocial problems. Current Problems in Pediatric and Adolescent Health Care, 32(8), 260-305.

Costa, M.V., Borges, F.A. (2015). O Pró-PET-Saúde frente aos desafios do processo de formação profissional em saúde. Interface: comunicação, educação e saúde, 19(1), 753-763.

Costa, S. M. \& Moraes, A. B. A. (1994). Medo em odontologia: um estudo com escolares. Revista Brasileira de Odontologia,51(5), 26-31.

Crossley, J., Eiser, C., Davies, H. A. (2005). Children and their parents assessing the doctor-patient interaction: A rating system for doctors' communication skills. Medical Education, 39(8), 820-828.

Cunha, E. M. S. (1952) História da odontologia no Brasil, 1500-1900. 2ed. Rio de Janeiro: Científica.

Darby, C. (2002). Patient/Parent assessment of the quality of care. Ambulatory Pediatrics, 2(4), 345-348.

Dias, H. S., Lima, L. D., Teixeira, M. (2013). A trajetória da política nacional de reorientação da formação de pessoal para o Sistema Único de Saúde. Ciência \& Saúde Coletiva, 18(6), 1613-1624. doi: 10.1590/S1413-81232013000600013.

Dicionário Online de Português. (2009). Acessado em 09 de Julho de 2019. Recuperado de https://www.dicio.com.br/chocado/.

DiMatteo, M. R. (2004). The role of effective communication with children and their families in fostering adherence to pediatric regimens. Patient Education and Counseling, 55(3), 339-344. 
Deslandes SF. (2004). Análise do discurso oficial sobre a humanização da assistência hospitalar. Ciênc. Saúde Coletiva, 9(1), 7-14.

DiMatteo, M. R. (2004). The role of effective communication with children and their families in fostering adherence to pediatric regimens. Patient Education and Counseling, 55(3), 339-344.

Dubé, C. E., LaMonica, A., Boyle, W., Fuller, B.; Burkholder, G. J. (2003). Self-assessment of communication skills preparedness: Adult versus pediatric skills. Ambulatory Pediatrics, 3(3), 137-141.

Erdman A.L, Souza F.G.M., Mochel E.G (2010). Modelando a integralidade do cuidado à criança na Atenção Básica de Saúde. Revista Gaúcha de Enfermagem. 31(4),701-7.

Ferreira, M.L.S.M., Cotta, R.M.M, Oliveira, M.S. (2008). Reconstrução teórica do cuidado para as práticas de saúde: um olhar a partir da produção de alunos de curso de especialização a distância. Rev Bras Educ Med. 32(3), 291-300. http://dx.doi.org/10.1590/S0100-55022008000300003

Ferreira, N. P., Ferreira, A. P., Freire, M. C. M. (2013). Mercado de trabalho na odontologia: contextualização e perspectivas. Rev Odontol UNESP. 42(4), 304-309.

Fertonani, H. P., Pires, D. E. P., Biff, D., Scherer, M. D. A. (2015). Modelo assistencial em saúde: conceitos e desafios para a atenção básica brasileira. Ciência \& Saúde Coletiva, 20(6), 1869-1878. doi: 10.1590/1413-81232015206.13272014

Forte F.D.S, Pessoa T.R.R.F., Freitas C.H.S.M, Pereira C.A.L, Carvalho Junior P.M. (2015). Reorienting dental education: the preceptor's view of supervised internship in the Brazilian Health System (SUS). Interface (Botucatu), 19 Supl 1, 831-43.

Goulart, B. N. G., Chiari, B. M. (2010). Humanização das práticas do profissional de saúde: contribuições para reflexão. Ciência \& Saúde Coletiva, 15(1), 255-268. doi: 10.1590/S1413-81232010000100031

Guedes, C. R., Nogueira, M. I., Camargo Jr., K. R. (2006). A subjetividade como anomalia: contribuições epistemológicas para a crítica do modelo biomédico. Ciência \& Saúde Coletiva, 11(4), 1093-1103. doi: 10.1590/S1413-81232006000400030.

Guerra, C. T., Bertoz, A. P. M., Fajardo, R. S., Alves Rezende, M. C. R. (2014). Reflexões sobre o conceito de atendimento humanizado em Odontologia. Arch Health Invest 3(6), 31-36.

Howells, R., Lopez, T. (2008). Better communication with children and parents. Paediatrics and Child Health, 18(8), 381-385.

Hora, D. L., Souza, C. T. V. (2015). Ensino na saúde: propostas e praticas para a formação acadêmico-pedagógica de docentes. RECIIS - Revista Eletrônica de Comunicação, Informação \& Inovação em Saúde, 9(4), 1-12. Recuperado de https://www.reciis.icict.fiocruz.br/index.php/reciis/article/view/947/pdf 947. 
Ishara, S., Cardoso, C. L. (2013). Delineamento do Grupo Comunitário de Saúde Mental. In S. Ishara, C. L. Cardoso, \& S. R. Loureiro (Orgs.), Grupo Comunitário de Saúde Mental: Conceito, delineamento metodológico e estudos (pp.19-40). Ribeirão Preto, SP: Nova Enfim Editora.

Kohlsdorf, M., Costa Junior, A. L. (2013). Comunicação em pediatria: revisão sistemática de literatura. Estud. psicol. (Campinas) [online]. 30(4), 539-552. ISSN 0103-166X. http://dx.doi.org/10.1590/S0103-166X2013000400007.

Koifman, L. (2001). O modelo biomédico e a reformulação do currículo médico da Universidade Federal Fluminense. História, Ciências, Saúde - Manguinhos, VIII (1), 48-70, mar.-jun.

Lazzarin H. C, Nakama L, Cordoni Júnior L. (2007). O papel do professor na percepção dos alunos de odontologia. Saúde Soc.16 (1), 90-101.

Lima, E. N. A., Souza, E. C. F. (2010) Percepção sobre ética e humanização na formação odontológica. Revista Gaúcha Odontol., 58(2), 231-238.

Mattos, R. A. (2008). Integralidade, trabalho, saúde e formação profissional: algumas reflexões críticas feitas com base na defesa de alguns valores. In G. C. Matta \& J. C. F. Lima (Orgs.), Estado, sociedade e formação profissional em saúde: contradições e desafios em 20 anos de SUS (p. 313-352). Rio de Janeiro, RJ: Fiocruz/EPSJV.

Merhy E. E. A perda da dimensão cuidadora na produção da saúde: uma discussão do modelo assistencial e da intervenção no seu modo de trabalhar a assistência. Campinas: Unicamp; 1998. Acessado em 09 de Julho de 2019. Recuperado de https://www.researchgate.net/publication/33023409 A perda da dimensao cuidado ra na producao da saude uma discussao do modelo assistencial e da interve ncao no seu modo de trabalhar a assistencia

Merhy, E. E.; Feuerwecker, L.; Gomes, M. P. C. (2010). Da repetição à diferença: construindo sentidos com o outro no mundo do cuidado. In: T.B. Franco, (Org.). Semiótica, afecção \& cuidado em saúde (pp. 60-75). São Paulo, SP: Hucitec.

Merhy, E. E. (1999) O ato de cuidar como um dos nós críticos chaves dos serviços de saúde. Acessado em 09 de Julho de 2019. Recuperado de https://www.pucsp.br/prosaude/downloads/bibliografia/ato cuidar.pdf

Milgrom, P., Mancl, L., King, B., Weinstein, P. (1995). Origins of childhood dental fear. Behav Res Ther., 33(3), 313-9.

Minayo, M. C. (2004) O desafio do conhecimento - pesquisa qualitativa em saúde. 8.ed. São Paulo: Hucitec.

Monteiro AI, Lima KYN, Santos ADB, Teixeira GB, Macêdo IP. (2012). Humanização do atendimento à criança na atenção básica: visão dos profissionais. Rev Rene. 13(4), 724-33. 
Moraes, A. B. A., Ambrosano, G. M. V., Possobon, R. de F. (2004). Fear assessment in Brazilian children: The relevance of dental fear. Psicologia: Teoria e Pesquisa, 20(3), 289-294.

Moraes, A. B. A., Costa Junior, A. L., Rolim, G. S. (2004). Medo de dentista: ainda existe? In M. Z. S. Brandão (Org.), Sobre Comportamento e cognição (pp. 171-178). Santo André, SP: Esetec.

Moreira, C. O. F., \& Dias, M. S. A. (2015). Diretrizes Curriculares na saúde e as mudanças nos modelos de saúde e educação. ABCS Health Sciences, 40(3), 300-305. doi: 10.7322/abcshs.v40i3.811.

Mota, L. Q., Farias, D. B. L. M., Santos, T. A. (2012). Humanização no atendimento odontológico: acolhimento da subjetividade dos pacientes atendidos por alunos de graduação em Odontologia. Arq Odontol, Belo Horizonte, 48(3), 151-158, jul/set.

Moreti-Pires, R. O. (2008) O pensamento crítico social de Paulo Freire sobre a humanização e o contexto da formação do enfermeiro, do médico e do odontólogo. (Tese de Doutorado, Escola de Enfermagem de Ribeirão Preto, Universidade de São Paulo). Recuperado de http://www.teses.usp.br/teses/disponiveis/22/22131/tde26032008-131633/pt-br.php

Moyses, S. T., Moyses, S. J., Krieger, L. et al. (2003). Humanizando a Educação em Odontologia. Revista Abeno, 3 (1), 58-64.

Nobile, C., Drotar, D. (2003). Research on the quality of parent-provider communication in pediatric care: Implications and recommendations. Developmental and Behavioral Pediatrics, 24(4), 279-290.

Nora, C. R. D; Junges, J. R. (2013). Humanization policy in primary health care: a systematic review. Revista de Saúde Pública, 47(6), 1186-200.

Nuto, S. A. S. N., Noro, L. R. A., Cavalsina, P. G., et al. (2006). O processo ensinoaprendizagem e suas consequências na relação professor-aluno-paciente. Ciência \& Saúde Coletiva, 11(1), 89-96.

Pereira, A. D.; Freitas, H. M. B.; Ferreira, C. L. L.; Marchiori, M. R. C. T.; Souza, M. H. T.; Backes, D. S. (2010). Atentando para as singularidades humanas na atenção à saúde por meio do diálogo e acolhimento. Revista Gaúcha de Enfermagem, 31(1), 55-61.

Piani, P. P. F., Reis, J. A. R., Cardoso, M. R. O., Reis, L. O. C. (2014). A integralidade e as práticas em saúde da criança: uma revisão narrativa da produção científica brasileira. Revista Paranaense de Medicina. 8 (4), 65-76.

Porto, M. A. T. (1994). A circulação do sangue, ou o movimento no conceito de movimento. História, Ciências, Saúde - Manguinhos, I (1), 19-34.

Possobon, R. F., Carrascoza, K. C., Moraes, A. B. A. \& Costa Júnior, A. L. (2007). Psicologia em Estudo, Maringá, v. 12, n. 3, p. 609-616, set./dez. 
Raldi, D. P., Malheiros, C. F., Fróis, I. M. et al. (2003). O papel do professor no contexto educacional sob o ponto de vista dos alunos. Revista Abeno, 3 (1), 15-23.

Rider, E. A., Volkan, K., \& Hafler, J. P. (2008). Pediatric resident's perceptions of communication competencies: Implications for teaching. Medical Teaching, 30(7), 208-217.

Rolim, G. S., Moraes, A. B. A., César, J. \& Costa Júnior, A. L. (2004). Análise do Comportamento do Odontólogo no Contexto do Atendimento Infantil. Estudos de Psicologia. 9 (3), 533-541.

Rosenthal E. A. (2001). Odontologia no Brasil no século XX. São Paulo, SP: Santos.

Rosito, M. M. B., Loterio, M. G. (2012). Formação do profissional em saúde: uma recusa ao esvaziamento da essência do cuidado humano. Educação \& Realidade, 37(1), 125142. Recuperado de http://seer.ufrgs.br/index.php/educacaoerealidade/article/view/21802/16022

Safra, G. (2004). A Po-ética na Clínica Contemporânea. $2^{\underline{a}}$ ed. Aparecida, SP: Idéias \& Letras.

Scalioni, F. A. R., Alves, R. T., Mattos, C. L. B., Ribeiro, R. A. (2008). Humanização na Odontologia: a Experiência da Disciplina Odontopediatria II do Curso de Graduação em Odontologia da UFJF. Pesq Bras Odontoped Clin Integr, João Pessoa, 8(2),185190, maio/ago.

Silva, L. P. P., Moraes, A. B. A., e Rolim, G. S. (2008). Efeitos de Procedimento de Distração Não Contingente em Tratamento Odontopediátrico. Interação em Psicologia, 12(2), p. 179-187.

Silva, R. H. A., Sales-Peres, A. (2007). Odontologia: um breve histórico. Odontologia Clín.Científ, Recife, 6 (1), 7-11.

Silva, V. O., Santana, P. M. M. A. (2015). Conteúdos curriculares e o Sistema Único de Saúde (SUS): categorias analíticas, lacunas e desafios. Interface - Comunicação, Saúde, Educação, 19(52), 121-132. doi: 10.1590/1807-57622014.0017

Tiedmann C. R, Linhares E, Silveira J.L.G.C. (2005). Clínica integrada odontológica: perfil e expectativa dos usuários e alunos. Pesq Bras Odontoped Clín integr; 5(1), 53-8.

Turato, E. R. et al. (2008). Amostragem por saturação em pesquisas qualitativas em saúde: contribuições teóricas. Cadernos de Saúde Pública, Rio de Janeiro, 24(1), 1727.

Turato, E. R. (2005). Métodos qualitativos e quantitativos na área da saúde: definições, diferenças e seus objetos de pesquisa. Rev. Saúde Pública, São Paulo, 39(3), 507514. 
Usual A. B. et al. (2006) Necessidades sentida e observada: suas influências na satisfação de pacientes e profissionais. Arquivos em Odontologia, Belo Horizonte, v. 42, n. 1, p. $1-80$, jan./mar.

Viotti, A. C. C. (2012). As práticas e os saberes médicos no Brasil colonial (1677 - 1808). (Dissertação de Mestrado, Faculdade de Ciências Humanas e Sociais, Universidade Estadual Paulista "Júlio de Mesquita Filho"). Recuperado de https://www.franca.unesp.br/Home/Pos-graduacao/dissertacao-final ana-carolinaviotti.pdf 


\section{APÊNDICE A}

\section{TERMO DE CONSENTIMENTO LIVRE E ESCLARECIDO}

Você está sendo convidado (a) a participar voluntariamente da pesquisa intitulada "Atendimento Odontopediátrico na Clínica-escola: um estudo da experiência dos estudantes de Odontologia", que tem como objetivo compreender a experiência dos estudantes de Odontologia em relação ao tratamento odontopediátrico prestado na Clínica-escola. O estudo será realizado

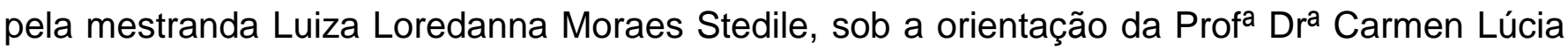
Cardoso, docente da Faculdade de Filosofia Ciências e Letras de Ribeirão Preto da Universidade de São Paulo (FFCLRP-USP), e se justificativa na medida em que compreender a formação e as experiências dos estudantes na área da Odontopediatria pode colaborar com a identificação de problemas e, a partir disso, gerar melhorias no ensino e nos serviços com ações mais eficazes, visando promover a humanização. Sua participação será através de uma entrevista, em local a ser combinado, que será realizada pela própria pesquisadora responsável (Luiza Loredanna Moraes Stedile). Tal entrevista será individual com duração aproximada de 40 minutos e serão abordados temas referentes à sua formação em Odontopediatria, à supervisão/orientação recebida e à relação com pacientes, bem como à humanização do trabalho realizado. Será audiogravada, com seu consentimento, para que possamos realizar a transcrição exata dos dados informados e assim utilizá-los nas futuras publicações dos resultados deste estudo. Os áudios serão arquivados pela pesquisadora durante 5 anos e destruídos após este período. Apesar de não haver riscos previsíveis na participação, apresentase como um possível risco decorrente da entrevista algum desconforto psicológico que possa ser causado pelas perguntas realizadas.

Como benefícios esperados deste estudo, acreditamos que seus resultados poderão ajudar no planejamento de estratégias para melhorar o ensino e a aprendizagem no que se refere à humanização das relações, dos profissionais e das práticas em Odontopediatria.

Ao aceitar participar, você deve estar ciente que sua identidade será mantida em sigilo durante e após a conclusão deste estudo, sua participação é totalmente voluntária e que você pode desistir a qualquer momento que julgar necessário sem prejuízo algum, implicando no descarte imediato de suas informações prestadas.

Você não terá nenhum gasto ao participar deste estudo, portanto, não haverá nenhuma forma de reembolso em dinheiro. Caso você precise se deslocar ao local de aplicação 
exclusivamente para participar do estudo, a Pesquisadora Responsável (Luiza Loredanna Moraes Stedile) irá reembolsar o valor gasto com o transporte.

Você ficará com uma via deste termo de consentimento, assinada pela pesquisadora responsável e por sua orientadora.

Caso haja alguma dúvida relacionada aos aspectos éticos desse estudo você pode entrar em contato com o Comitê de Ética em Pesquisa da Faculdade de Filosofia de Ribeirão Preto USP. O Comitê está localizado na Avenida Bandeirantes, 3900 - Bloco 23 - Casa 37, na cidade de Ribeirão Preto - SP - Brasil. Cep: 14040-901. O Telefone para contato é (16) 3315-4811 e o email é coetp@ffclrp.usp.br

Demais dúvidas com relação a sua participação poderão ser esclarecidas com a pesquisadora responsável ou com a professora que orienta o estudo, a qual poderá ser encontrada no endereço: Av. Bandeirantes, no 3900, Faculdade de Filosofia, Ciências e Letras de Ribeirão Preto - FFCLRP. Departamento de Psicologia, Bloco 5, sala 33. CEP: 14040-901, Ribeirão Preto-SP. Telefone: (16) 3315 - 3660.

\section{Muito Obrigada pela sua colaboração!}

$\mathrm{Eu}$,

aceito participar voluntariamente do estudo proposto neste Termo. Declaro ainda que concordo inteiramente com as condições que me foram apresentadas e que, livremente, manifesto a minha vontade em participar da referida pesquisa.

Ribeirão Preto, de de 201

\section{Assinatura do Participante}

Luiza Loredanna M. Stedile Mestranda
Profa Drª Carmen Lúcia Cardoso Orientadora 
123

ANEXO 


\section{ANEXO A}

\section{Parecer Consubstanciado do Comitê de Ética em Pesquisa da FFCLRP-USP}

Prezado(a) Pesquisador(a),

Comunicamos a V. Sa. que o projeto de pesquisa intitulado "Atendimento Odontopediátrico na Clínica-escola: um estudo da experiência dos estudantes de odontologia." foi analisado pelo Comitê de Ética em Pesquisa da FFCLRP-USP, em sua $160^{a}$ Reunião Ordinária, realizada em 20.10.2016, e enquadrado na categoria: APROVADO (CAAE $n^{\circ}$ 60219816.6.0000.5407).

Solicitamos que eventuais modificações ou emendas ao projeto de pesquisa sejam apresentadas ao CEP, de forma sucinta, identificando a parte do projeto a ser modificada e suas justificativas. De acordo com a Resolução n466 de 12/12/2012, devem ser entregues relatórios semestrais e, ao término do estudo, um relatório final sempre via Plataforma Brasil.

Atenciosamente,

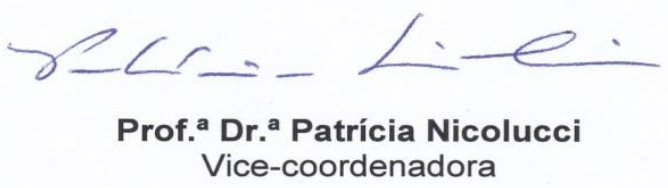

Ao(À) Senhor(a)

Luiza Loredanna Moraes Stedile

Programa de Pós-graduação em Psicologia da FFCLRP/USP

CEP - Comitê de Ética em Pesquisa da FFCLRP USP

Fone: (16) 3315-4811

Avenida Bandeirantes, 3900 - bloco 23 - casa 37 - 14040-901 - Ribeirão Preto - SP - Brasil Homepage: http://www.ffclrp.usp.br - e-mail: coetp@ffclrp.usp.br 